\title{
Kinematic sequence stratigraphy of the European Cenozoic Rift System and Alpine Foreland Basin: correlation with Mediterranean and Atlantic plate-boundary events
}

\section{W. Sissingh}

Faculty of Earth Sciences, Utrecht University, Budapestlaan 4, 3584 CD Utrecht, The Netherlands. Email: w.sissingh@geo.uu.nl

Manuscript received: January 2005; accepted: February 2006

\begin{abstract}
A review of the sequence stratigraphic development of the Tertiary basins of the North and West Alpine Foreland domains shows that their structural and depositional history was episodically affected by brief tectonic phases. These were associated with intermittent deformation events induced by the collisional convergence and compressional coupling of the Apulian and Iberian microplates with the European Plate. The plate kinematics-related episodicity was essentially isochronously recorded in the basin fills of the Alpine Foreland region. These are generally correlative with changes in eustatic sea level. The ensuing correlative successions of so-called Cenozoic Rift and Foredeep (CRF) sequences and phases can be traced throughout the European Cenozoic Rift System and Alpine Foreland Basin. Their temporal correlation indicates that, apparently, the changes in the plate collision-related stress regime of the Alpine Foreland were repeatedly accompanied by coeval changes in eustatic sea level. To test and substantiate the validity of this inferred causal relationship between intraplate deposition, plate kinematics and eustacy, the tectonosedimentary evolution of the basins of the Mediterranean plate-boundary zone has been analysed in conjunction with a review of the plateboundary events in the North Atlantic. Within the uncertainty range of available datings, synchroneity could thus be demonstrated for the punctuated tectonostratigraphic development of basins of the western Mediterranean (comprising the Liguro-Provençal Basin, Valencia Trough, Sardinia Rift and Tyrrhenian Basin), the Apenninic-Calabrian Arc, the Betic domain (including the Alboran Basin) and the North and West Alpine Foreland regions. Similar temporal correlations of plate tectonicsrelated events near the Mid-Atlantic Ridge in the North Atlantic and tectonostratigraphic sequences and phases of the Alpino-Pyrenean Foreland basins are further evidence of a common causal mechanism. The driving mechanisms appear to have been the northward drift of Africa and the resulting mechanical coupling of Apulia and Iberia with the southern passive margin of Europe, as well as the stepwise opening of the North Atlantic and accompanying episodic plate re-organisations of the Mid-Atlantic Ridge.
\end{abstract}

Keywords: Alpine Foreland Basin, European Cenozoic Rift System, Mediterranean Basin, North Atlantic Ocean, plate kinematics, sequence stratigraphy, tectonics

\section{Introduction}

The post-Variscan crustal deformation in Western and Central Europe is characterised by polyphase epeirogenetic movements, which were expressed by long-term episodes of regional subsidence and uplift of the crust, separated by brief tectonic phases of more rapid differential movements of crustal blocks. Within a plate-kinematic context, numerous studies of the temporal changes of the tectonic stress regime of the European lithosphere have demonstrated a close causal relationship between geodynamic processes at the Europe-Africa plate boundary and deformations of the fractured European Plate.
The northern forelands of the Alpine and Pyrenean thrustand-fold belts include Cenozoic basins with sedimentary fills which have been affected by brittle deformation that occurred in response to the collisional convergence of the African, Apulian and Iberian plates with the European Plate (Figs 1 and 2). These motions were related to an evolving, synorogenic system of plate interaction that was governed by the middle to late Alpine collision and, following a Late Eocene main collisional coupling of the converging plates at crustal levels, so-called 'post-collision' phases of the convergence of the African and European plates. In general, the accompanying changes in compression and extension of the West European 
Platform occurred coevally with the orogenic events in the Alpine collision zone. Altogether, these tectonic events appear to have been induced by the collision of the Alpine and Pyrenean orogenic wedges with the European passive margin and the overthickening and uplifting of those orogenic wedges during the later, 'post-collision' stage of the Alpine orogeny (e.g. Ziegler et al., 1998). Though temporally and spatially variable, both the collision and 'post-collision' stress regimes at the European-African plate boundary represent overall increased mechanical coupling of the orogenic wedges with both their forelands and hinterlands. Far-field transmission of the orogen-derived stresses resulted in vertical and horizontal movements of crustal blocks along pre-existing fault systems in the adjacent foreland and hinterland domains. In addition, transmission of stress led to new fault systems commonly following trends of the older, re-activated systems. The associated intra-plate compression and extension of the Alpino-Pyrenean Foreland, i.e. the southern part of the West European Platform that was most affected by the collision of the Apulian, Iberian and European plates, resulted in two dominant tectonic features : (1) the Alpine Foreland Basin and (2) the European Cenozoic Rift System (Fig. 1; Encls 1 and 2).

In the Alpino-Pyrenean Foreland the collision induced by the Africa-Europe convergence caused buckling and folding of the lithosphere during the Early Tertiary. Horizontal compression of the relatively low-strength crust re-activated pre-existing faults and led to inversion and uplifting of Mesozoic basins. The intensity of this inversion decreased with increasing distance from the Alpine thrust front (Ziegler et al., 1995). Throughout this period, as well as during later Tertiary times, compressive stresses were intermittently 'projected' from the Alpine collision zone into the foreland, with different directions and magnitudes. As indicated for the Recent by the World Stress Map (Zoback \& World Stress Map Team, 1989; Zoback, 1992), horizontal compressive stress can be transmitted over very large distances through both continental and oceanic lithosphere. There is every reason to assume that during the Tertiary comparable far-field stress transmission did occur in the Alpino-Pyrenean Foreland. The regional compilations of present-day stress indicators in Western and Central Europe (Grünthal \& Stromeyer, 1986; Rebaï et al., 1992; Müller et al., 1992; Gölke \& Coblentz, 1996) have demonstrated a regionally rather uniform, NW to NNW orientation of the maximum horizontal compressive stress. Numerical modelling has shown that both the orientation and magnitude of this regional stress field are remarkably consistent and invariant despite different boundary conditions used to represent the tectonic forces acting along the southern and eastern plate margins. This regionally uniform stress orientation is (sub)parallel to the general direction of the convergent plate motion between Africa and Europe, that was governed by the Indian, South Atlantic, and North Atlantic ridge-push forces (Fig. 2). It also matches the

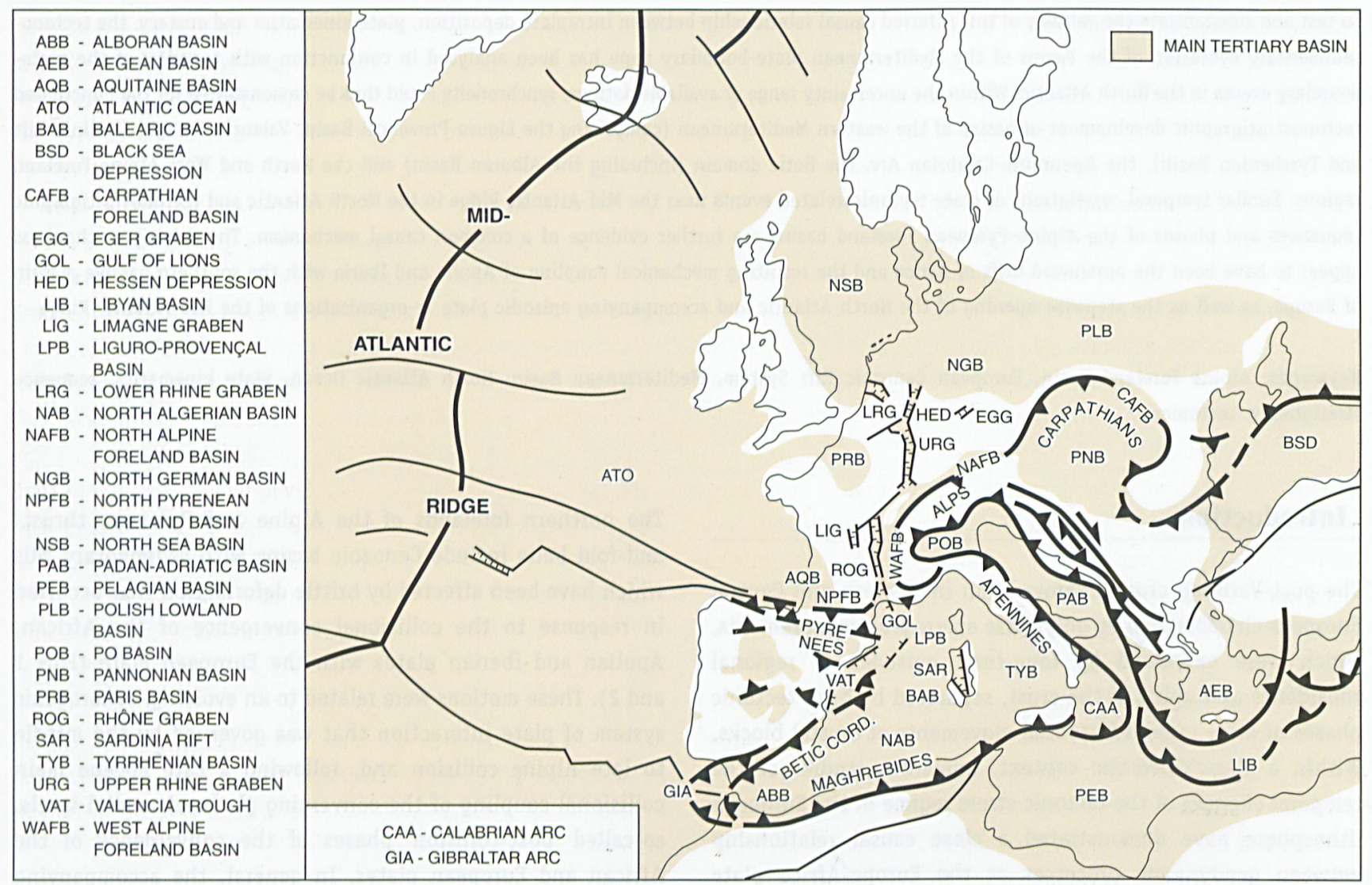

Fig. 1. Main Tertiary tectonic features and basins of Western and Central Europe, the western Mediterranean and the northern Atlantic. 


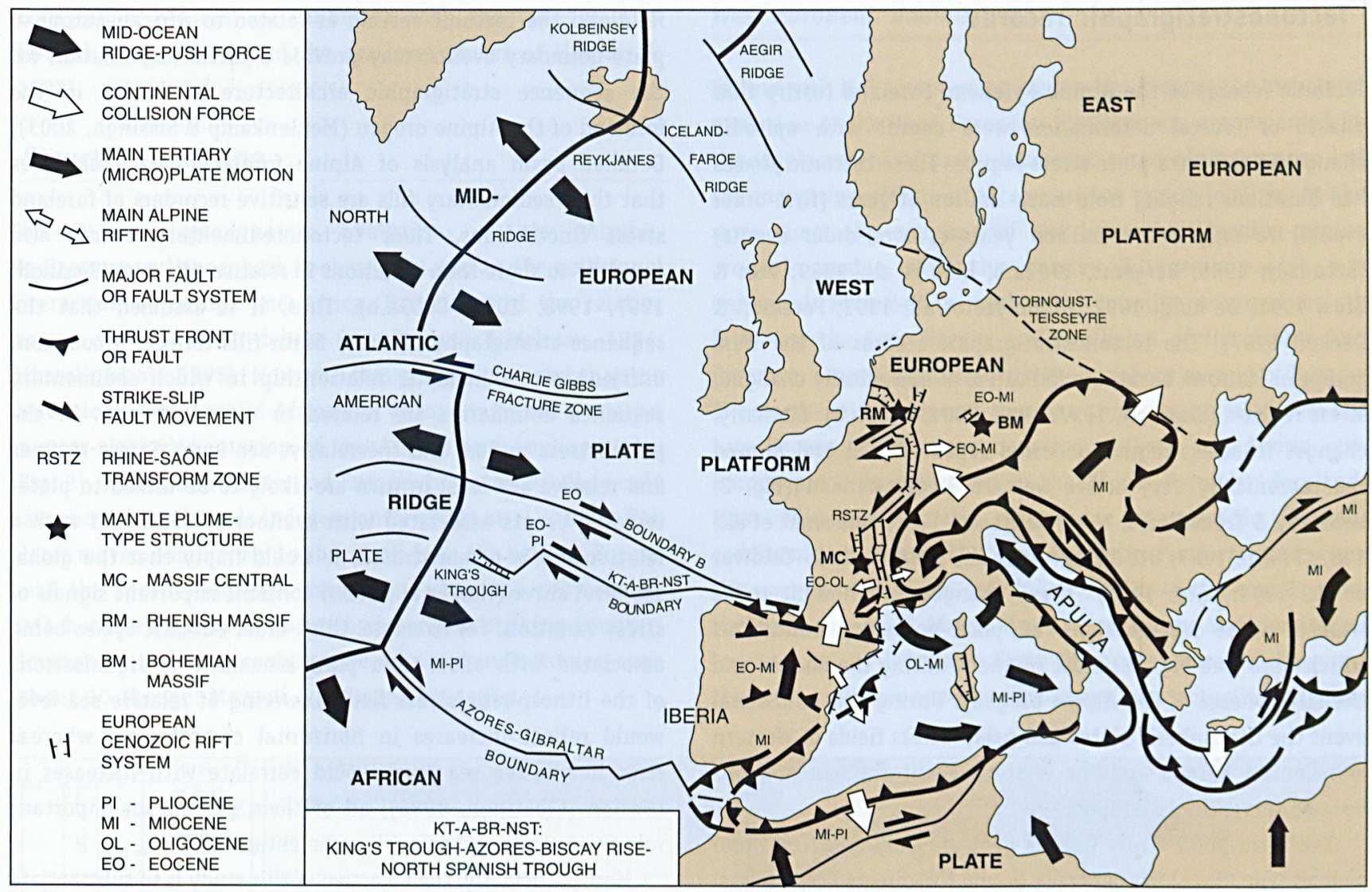

Fig. 2. Main Tertiary plate-kinematic motions in Western and Central Europe, the western Mediterranean and the northern Atlantic.

general direction of the horizontal compressive stresses which are projected northwards from the European-African plateboundary zone located in the western Mediterranean (Udias \& Buforn, 1993). The NW-SE compression of the present West European Platform thus testifies to the predominance of Alpine collision forces induced by plate-tectonic activity in the Mediterranean. However, platform areas subjected to recent tectonic deformation and seismo-tectonic activity, such as the western Alps and the northern Pyrenees, may display important deviations from the general stress directions (Rebaï et al., 1992) with local-scale variations being spatially associated with thrust, strike-slip and normal faults. The common occurrence of normal faulting within a compressive stress regime may be related to adjustive movements of upper crustal fragments which are decoupled from the lithospheric mantle by the relatively ductile lower crust. Affected by the Atlantic ridgepush force or the Alpine collision force, these fragments may have moved independently of each other and also relative to the mantle (Müller et al., 1997). In the West European Platform, the release of compressive stress was mainly through transpressional and transtensional movements along preexisting crustal block boundaries (Illies et al., 1981). These intra-plate stress releases affected both the collisional and 'post-collisional' evolution of the Alpine Foreland Basin and the syn- and post-rift development of the European Cenozoic Rift System (Encls 1 and 2).
The geographic location, as well as the overall orientation and basin configuration of both the pro-wedge North and West Alpine foreland basins and the retro-wedge North Pyrenean (Aquitaine) foreland basin (Figs 1 and 2), reflect flexural foredeep subsidence. This flexural subsidence was related to the convergence of Europe and Africa (including the Apulian and Iberian plates) and accompanying thrust-loading along the collision zone. In contrast, the European Cenozoic Rift System (Figs 1 and 2; Encls 1 and 2), the most important intra-plate tectonic feature of the West European Platform, reflects re-activation of pre-existing faults, crustal extension associated with intra-graben block-faulting and differential movements of the adjoining extra-graben crustal blocks. For both settings and types of basin development, it is likely that pre-existing crustal discontinuities that had weakened the lithosphere of the West European Platform played a role in the collision-induced flexuring and rifting.

Given this context of convergent plate motions and consequent changes of collision-related intra-plate stresses, the present paper focuses on the tectonostratigraphic correlations between the Alpino-Pyrenean Foreland and the Mediterranean and North Atlantic regions, on the basis of comparative sequence stratigraphic analyses of the Cenozoic basins. 


\section{Tectonostratigraphic records}

Tectonic records of the Alpino-Pyrenean Foreland testify that phases of crustal deformation were coeval with episodic changes in the intra-plate stress regime. These tectonic phases had durations ranging from many million of years (first-order events) to only a few million years (second-order events) (Letouzey, 1986; Bergerat, 1987a,b, Blès et al., 1989, Blès \& Gros, 1991; De Ruig, 1992; Hippolyte et al., 1993; Peresson \& Decker, 1997). The tectonostratigraphic records of the West European Platform basins are indicative of episodically changing stress regimes (Sissingh, 1997, 1998, 2001, 2003a,b). Similarly, changes in stress regime occurred repeatedly in and around the tectonically very active western Mediterranean (Fig. 2; Letouzey \& Trémolières, 1980; Letouzey, 1986; Montenat et al., 1987; Philip, 1987; 0tt d’Estevou et al., 1988; Galindo-Zaldívar et al., 1993; Aïte, 1995). These changes are thought to be related to re-organisations of plate-boundary conditions which were (see Fig. 28) most frequent during the Eocene and the later phases of the Alpine orogeny. During this collisional event the lithospheric plates and palaeostress fields of Western and Central Europe and the western Mediterranean domains became increasingly coupled.

The intra-plate stress field is controlled by two first-order sources (Fig. 2): (1) the generally N- and NW-directed continental collision forces, which originate along the southern margin of the European Plate, and (2) the ridge-push forces generated along the Mid-Atlantic Ridge as a consequence of ongoing seafloor spreading. Through their plate-tectonic interrelationship, these forces produced the temporally and spatially changing pattern of the intra-plate stress fields in Western and Central Europe. In the Alpino-Pyrenean Foreland, the northward- and westward-directed collision force dominated.

As is argued in this paper, there is strong evidence that during the Tertiary large-scale geodynamic processes controlled by the simultaneous E-W opening of the Atlantic 0cean and the S-N directed collision of Europe and Africa, resulted in variable stress regimes within the crust of the Alpino-Pyrenean Foreland. These variations in the regional stress field can be kinematically correlated with the sequence stratigraphic development in the different basins. Apparently, the internal stress regime of the sedimentary basins changed episodically in response to events at the collisional boundaries between the African, Apulian, Iberian, and European plates. It is therefore argued that the development of sedimentary sequences and unconformities in the Alpine Foreland Basin and European Cenozoic Rift System reflects coeval changes in the Atlantic and Mediterranean plate-boundary stress fields.

The stratigraphic records of tectonic phases and sedimentary sequences in the intra-plate basins allows unravelling of the interplay between plate-kinematic and depositional processes, and hence relating plate-tectonics and palaeogeography (Sissingh, 2006). Changes in the far-field intra-plate stress field and the tectonic setting as related to African-European plate-boundary events, may provide a partial explanation for the sequence stratigraphic architecture of basins in the foreland of the Alpine orogen (Meulenkamp \& Sissingh, 2003). Detailed basin analysis of Alpine foreland basins indicates that their sedimentary fills are sensitive recorders of foreland stress fluctuations. Their tectonosedimentary events also correlate to short-term variations in relative sea level (Sissingh, 1997, 1998, 2001, 2003a,b). Thus, it is assumed that the sequence stratigraphy of these basin fills reflects a common, unifying plate-kinematic relationship in which sedimentary sequence boundaries are related to coeval changes in the palaeostress regime and the relative sea level. Stress regimes and relative sea level in turn are likely to be linked to platetectonic events associated with seafloor spreading. If such a relationship is demonstrated, it would imply that the global sea-level curve (Haq et al., 1988) contains important signals of stress variation. For example, third-order eustatic cycles being associated with short-term plate-kinematic re-organisations of the lithospheric stress field. Lowering of relative sea level would reflect increases in horizontal compression, whereas rises in relative sea level would correlate with increases in tension (Cloetingh, 1986), all of them playing an important role in controlling basin-fill sedimentation.

Most particularly, the objective of this study is to substantiate the above mentioned stratigraphic interpretations concerning the plate-kinematic and depositional history of the AlpinoPyrenean Foreland. To that purpose, a tectonostratigraphic summary of the Alpine foreland basins is given. Special attention is paid to the temporal correlation of depositional sequences and short-term intra-foreland and intra-orogen tectonic events. The exact mode and extent of punctuated plate-kinematic stress transfer from the Mediterranean and Atlantic plate-boundary domains towards the Alpino-Pyrenean Foreland remains to be assessed geodynamically. However, it is clear that the African-European plate collision was a more important control on the Tertiary deformation and tectonostratigraphic evolution of the Alpino-Pyrenean Foreland than the opening of the Atlantic 0cean. The Alpine plate-collision forces deformed and displaced the upper crust much more than Atlantic ridge-push forces. This may be due to the associated seafloor spreading being relatively constant in terms of direction and rate.

To test the idea of a temporal interrelationship between Alpine foreland plate-kinematics and basin sedimentation, the stratigraphy of representative plate-boundary basins of the western Mediterranean has been analysed to document the plate-kinematic and depositional events which, within the accuracy of biostratigraphic and radiometric dating techniques, were synchronous with such events in the Alpine foreland domain. Finally, an attempt is made to correlate Alpine foreland and Mediterranean hinterland events with developments at the Mid-Atlantic seafloor spreading axis. As in previous studies, 
stratigraphic records are calibrated with the time scale of Harland et al. (1990) and the sea-level curves of Haq et al. (1988).

\section{Structural Setting}

The Tertiary geodynamic evolution of the AlpineMediterranean lithosphere is closely related to the collisional interaction of Europe and Africa. Particulars of the relative motion are still under debate (e.g. Mazzoli \& Helman, 1994; Albarello et al., 1995). However, it is generally agreed that the Cenozoic convergence of Africa and Europe involved a relative counter-clockwise rotation of the African and Apulian plates (Fig. 3). Relative to Africa and Europe, however, Apulia would have moved northwards independently (Platt et al., 1989). The plates moved dominantly to the north from the earliest Eocene until the Eocene-Oligocene transition, when the convergence path became slightly more northwesterly. A striking counterclockwise rotation in convergence occurred in Tortonian time (about 10 Ma ago: Mazzoli \& Helman, 1994; Fig. 3).

\section{West European domain}

In line with $\mathrm{N}-\mathrm{S}$ compression during the Eocene, the structural evolution of the West European Platform was accompanied by the emplacement of partly basement-cored Alpine nappes and the increasing effects of accompanying thrust loading. At the same time, the coupling of the lithosphere-loading Alpine orogenic wedge with the passive European margin was enhanced. Increases in mechanical coupling occurred mainly following the Late Eocene main collision of the Alpine and Pyrenean orogenic wedges with the southern margin of Europe. The north- and northwest-trending compression related to the Late Eocene collision and coupling of Iberia and Apulia with Europe probably interfered in the Alpino-Pyrenean Foreland. Most evidence for the occurrence of episodic far-field compressive pulses in the West European Platform dates from the post-Eocene period (see below). Prior to the Late Eocene, the convergence of Africa, Apulia and Europe was dominated by subduction. From the Early Oligocene onwards, however, the 'post-collision convergence phase' was actually collision-

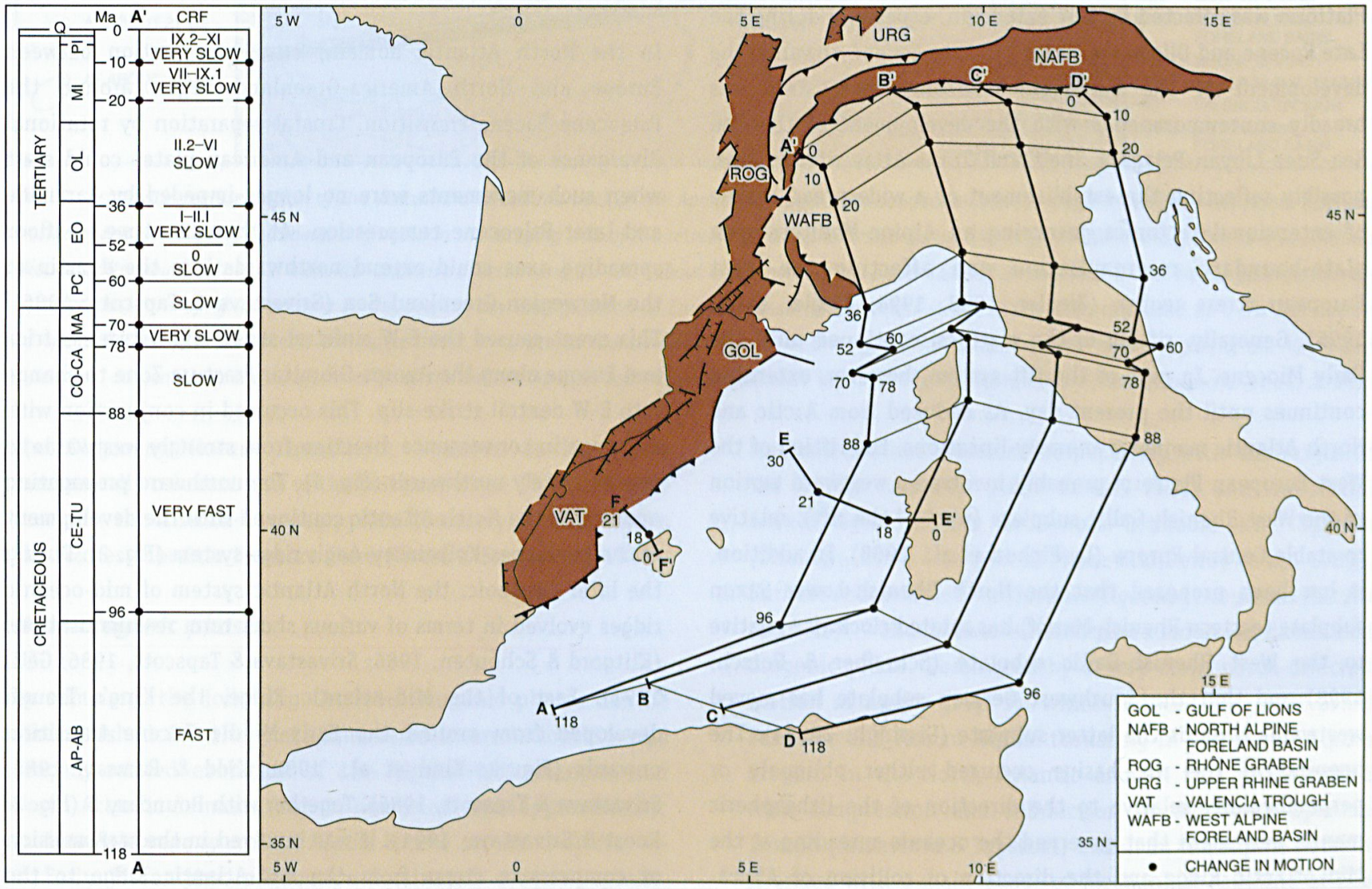

Fig. 3. Schematic representation of the plate-tectonic drift of Apulia relative to Europe by means of the convergence paths of four reference points, which migrated to the present-day northern Alpine thrust front during the Cretaceous and Cenozoic, as calculated from palaeogeographic reconstructions by Dewey et al. (1989). The approximate paths indicate convergence at different rates and with variable directions. The relatively low rates during the Eocene are related to accelerating lithospheric shortening and nappe stacking in the Alpine orogenic wedge. At the same time, rifting of the Upper Rhine and Rhône grabens in the Alpine pro-wedge foreland increased, probably in conjuction with increased transmission of collision-related, N-S striking compressive stresses from the Pyrenean and Alpine orogens into the conjugate Alpino-Pyrenean Foreland (which at the time included the area presently occupied by the doubly-vergent Alps). In turn, the increased compression is linked to enhanced mechanical coupling of the Iberian, Apulian and European plates. 
dominated. During this orogenic phase, the Alpine and Pyrenean wedges increased substantially in thickness, implying that basically only the lower crust was subducted. Earlier, structurally important phases of foreland compression occurred in the Paleocene. Through Late Paleocene intra-plate compression, Laramide and older features of the continental Alpine foreland were uplifted and degraded by erosion, whereas farther to the south, the development of the Alpine Foreland Basin was initiated by load-induced downflexing of the prowedge foreland crust by the nascent Alpine orogenic wedge (Allen et al., 1991). As indicated by the northward decreasing intensities of deformation, the Paleocene compressions reflect increased mechanical coupling between the Alpine orogen and the European foreland. Contemporaneously with Middle Eocene emplacement of Alpine precursor nappes, the Variscan basement and Mesozoic cover of the West European Platform was broken-up by the overall N-S trending European Cenozoic Rift System from close to the Early-Middle Eocene transition onwards (Figs 1 and 2; Encls 1 and 2; Ziegler, 1994; Prodehl et al., 1995; Sissingh, 1998; Dèzes et al., 2004). In tandem with plate-driven compression from the south, the West European Platform was affected by E-W extension, especially during the Late Eocene and Oligocene. From the Late Eocene onwards, the development of the European Cenozoic Rift System was broadly contemporaneous with the development of the Red Sea-Suez-Libyan-Pelagian Shelf and Trans-Atlas rift systems, possibly reflecting the establishment of a widespread regime of extensional tectonics governing an Alpine-Mediterranean plate-boundary re-organisation and affecting the West European stress regime (Ziegler, 1988, 1994; Ziegler et al. 1995). Generally, rifting of the platform continued until the Early Miocene. In part of the rift system, however, extension continues until the present day. As deduced from Arctic and North Atlantic magnetic anomaly lineations, the rifting of the West European Platform probably involved a westward motion of the West Rhenish-Gallic subplate (west of the rift), relative to stable Central Europe (Le Pichon et al., 1988). In addition, it has been proposed that the North Rhenish-Lower Saxon subplate (eastern Rhenish Massif) has rotated clockwise relative to the West Rhenish-Gallic subplate (Schreiber \& Rotsch, 1998) and that the Southwest German subplate has moved westwards towards the latter subplate (Sissingh, 2003a). The opening of the rift basins occurred either obliquely or perpendicularly relative to the direction of the lithospheric mantle movement that governed the oceanic spreading at the Mid-Atlantic Ridge and the direction of collision of AfricaApulia with Europe (Fig. 2). It has also been postulated that the crust of the West European Platform has moved laterally towards the southwest, relative to the underlying mantle and the East European Platform (Zeyen et al., 1997).

\section{West Mediterranean domain}

Overall, the orogenic belts bordering the western Mediterranean have an outward-directed structural polarity (Fig. 2). Since the late Paleogene, the intra-Mediterranean structuration was dominated by eastward-directed, probably intermittent rollback of the westward subducting Maghrebian-Apenninic lithospheric slab (Fig. 4; Gueguen et al., 1997; Carminati et al., 1998a,b; Roca, 2001). Thus, the structural evolution of the western Mediterranean Basin resulted in an interrelated series of tectonic subdomains defined by discontinuously-developed continental lithospheric necks isolating large-scale lithospheric boudins (Gueguen et al., 1997) and extensional back-arc basins in the hanging wall of the migrating lithospheric slab. These structures originated during a Late Oligocene - Early Miocene (about 30 - 16/15 Ma) and a later Miocene - Quaternary (9/8 - $0 \mathrm{Ma})$ main phase of basin opening, initially near the Iberian Peninsula and finally in the Tyrrhenian Sea (Figs 1, 2 and 4; Doglioni et al., 1997, 1999; Carminati et al., 1998b).

\section{North Atlantic domain}

In the North Atlantic domain, crustal separation between Europe and North America-Greenland began around the Paleocene-Eocene transition. Crustal separation by rotational divergence of the European and American plates could start when such movements were no longer impeded by Laramide and later Paleocene compression. At the same time, seafloor spreading axes could extend northwards into the domain of the Norwegian-Greenland Sea (Srivastava \& Tapscott, 1986). This event caused the E-W sinistral strike-slip between Africa and Europe along the Azores-Gibraltar Fracture Zone to change into E-W dextral strike-slip. This occurred in conjunction with a change in convergence direction from strongly westwards to approximately northwards (Fig. 3). The northward propagating opening of the North Atlantic continued with the development of the Reykjanes-Kolbeinsey-Aegir ridge system (Fig. 2). During the later Cenozoic, the North Atlantic system of mid-oceanic ridges evolved in terms of various short-term re-organisations (Klitgord \& Schouten, 1986; Srivastava \& Tapscott, 1986; Géli, 1991). East of the Mid-Atlantic Ridge, the King's Trough developed from around the Early-Middle Eocene transition onwards (Fig. 2; Kidd et al., 1982; Kidd \& Ramsay, 1986; Srivastava \& Tapscott, 1986). Together with Boundary B (Fig. 2; Roest \& Srivastava, 1991), it was involved in the transmission of compressive stress from the Mid-Atlantic Ridge to the Pyrenean convergence zone during the Eocene collision of the Iberian and European plates and the N-S subduction of the North Spanish Trough in the earliest Oligocene (Fig. 2; Srivastava \& Tapscott, 1986). This fracture system coincided with the African-European plate boundary until the late Middle Eocene, when Iberia decoupled from Africa and became kinematically independent (Roest \& Srivastava, 1991). Around 


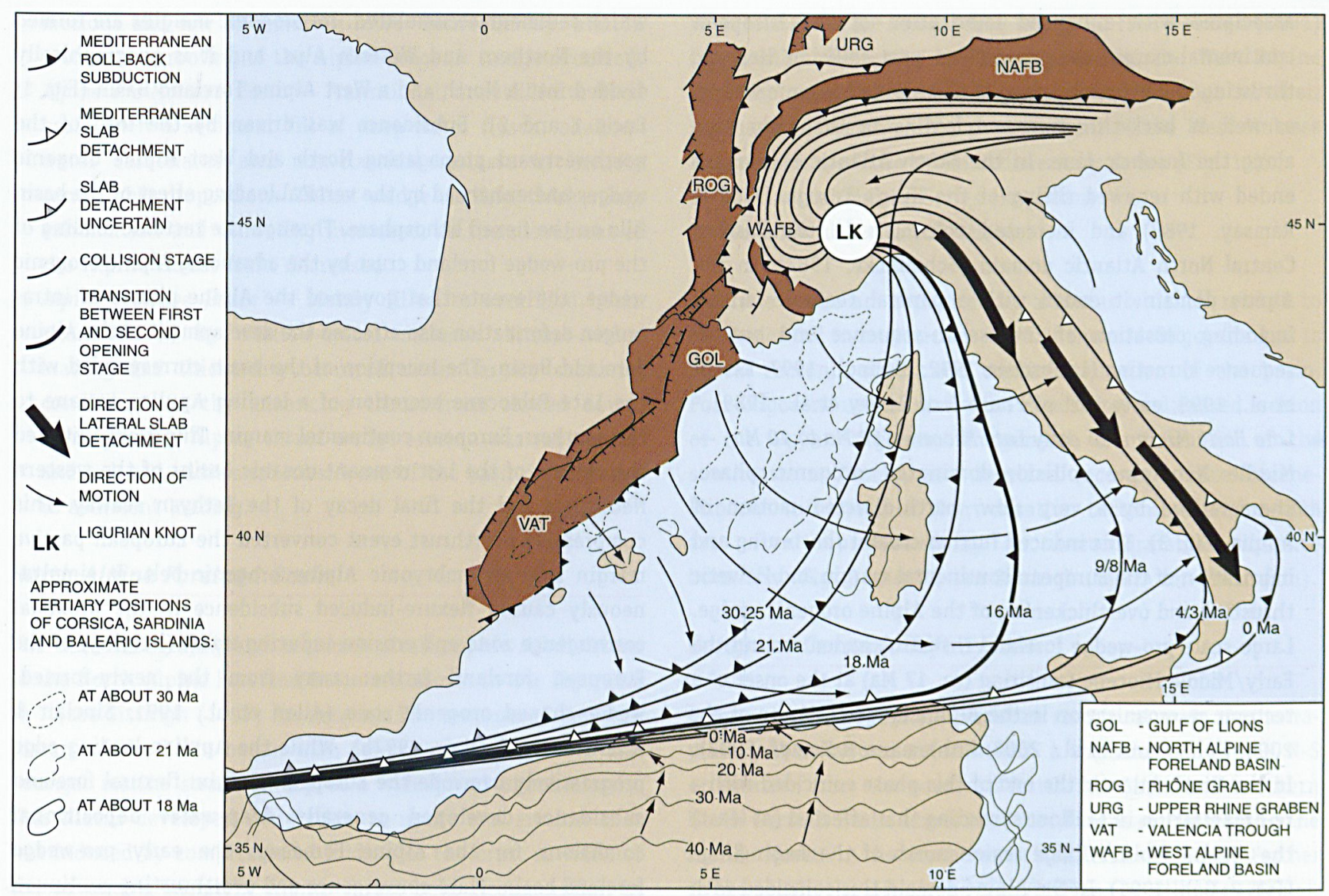

Fig. 4. Schematic representation of the eastward-directed roll-back of the Apenninic-Maghrebian subduction zone through which the extensional back-arc basins of the western Mediterranean originated in the hanging wall of the retreating lithospheric slab during the Oligocene-Quaternary. The Corsica-Sardinia Block simultaneously rotated in a counter-clockwise direction over $25-30^{\circ}$ about a pole north of the present Gulf of Genova. Also shown are the palinspasticallyrestored positions of Africa relative to the present-day configuration of Europe (based on Carminati et al., 1998b). Accompanied by a NW translation of Apulia since the Late Oligocene, the Alpine thrust front rotated counter-clockwise around the Ligurian Knot, the structural-kinematic join of the Alpine and Apenninic orogens near the southern edge of the salient Apulian Indenter, its kinematic link with the Apenninic thrust front (Laubscher et al., 1992).

the Oligocene-Miocene transition, however, it became a mechanically coherent part of the European Plate. From that time onwards, the African-European plate boundary coincided with the Azores-Gibraltar Fracture Zone (Roest \& Srivastava, 1991).

\section{Main orogenic phases}

In summary, the following Cenozoic orogenic phases can be distinguished for the plate-kinematic interrelationship and orogeny-related evolution of the Alpine-Mediterranean and North Atlantic domains (Fig. 3; numerical ages approximate):

1. Late Paleocene to earliest Middle Eocene (60 Ma to $52 \mathrm{Ma}$ ) Early Mesoalpine subduction-dominated orogenic phase. Characterised by a relatively slow, strongly west-directed motion of Apulia (Fig. 3). It started in the North Atlantic with the formation of the Azores-Biscay Rise and ended in this domain with the initiation of the King's TroughAzores-Biscay Rise-North Spanish Trough Fracture Zone (Kidd \& Ramsay, 1986; Srivastava \& Tapscott, 1986). Initiation and termination in the pro-wedge Alpine foreland domain coincided respectively with the origin of the Alpine Foredeep (Allen et al., 1991) and the initial development of the European Cenozoic Rift System (Sissingh, 1998; late part of Phase 3 of Dewey et al., 1989).

2. Earliest Middle Eocene to Eocene-Oligocene transition ( $52 \mathrm{Ma}$ to $36 \mathrm{Ma}$ ) - Middle to late Mesoalpine subduction-dominated orogenic phase. Dominated by a very slow, north-directed motion of Apulia (Fig. 3), which induced basement-cored Penninic and Austro-Alpine thrusting in the initial Alpine orogen. In the North Atlantic domain this phase ended with compression and subduction of the North Spanish Trough (Srivastava \& Tapscott, 1986). In the Alpine domain it ended with a main phase of mechanical coupling of the Apulian and European plates during final Penninic and Austro-Alpine thrusting of the Alpine orogenic wedge (Sissingh, 1997; Phase 4 of Dewey et al., 1989).

3. Eocene-Oligocene transition to mid-Early Miocene (36 Ma to $20 \mathrm{Ma}$ ) - Late Mesoalpine to early Neoalpine collisiondominated phase. Characterised by slow, north-directed motion of Apulia (Fig. 3). This resulted in crustal shortening 
associated with enhanced imbrication of the European continental margin and pronounced 'post-collision' Helvetic thrusting and overthickening of the Alpine orogenic wedge, as well as back-thrusting and folding in the early Alps along the Insubric Line. In the North Atlantic this phase ended with renewed rifting of the King's Trough (Kidd \& Ramsay, 1986) and increased volcanism in the Eastern Central North Atlantic domain (Schmincke, 1982). In the Alpine domain it ended with a general tectonic 'crisis', including cessation of intense in-sequence and out-ofsequence thrusting (Laubscher, 1992; Sissingh, 1997; Kempf et al., 1999; early part of Phase 5 of Dewey et al., 1989).

4. Late Early Miocene to early Late Miocene (20 Ma to $10 \mathrm{Ma}$ ) Middle Neoalpine collision-dominated orogenic phase. Characterised by a very slow, north-directed motion of Apulia (Fig. 3). This induced further crustal shortening and imbrication of the European continental margin and Helvetic thrusting and overthickening of the Alpine orogenic wedge. Large-scale pro-wedge foreland thrusting ended around the Early/Middle Miocene transition (ca. $17 \mathrm{Ma}$ ) at the onset of a tectonic re-organisation in the Alpine orogen (Márton et al., 2000; Kuhlemann et al., 2001; Kuhlemann \& Kempf, 2002). In the North Atlantic the end of this phase coincided with a re-organisation in seafloor spreading that affected (at least) the distant Mohn's Ridge region north of the Aegir Ridge (Fig. 2; Géli, 1991). In the Alpine domain this coincided with migration of crustal deformation onto the West European Platform and outward fanning from the western Alpine orogenic wedge in association with another major tectonic resetting of the orogen (Sissingh, 1997, 2001; Kuhlemann et al., 2001; late part of Phase 5 of Dewey et al., 1989).

5. Late Late Miocene-Recent (10 Ma to O Ma) - Late Neoalpine collision-dominated orogenic phase. Corresponds to a very slow, northwest-directed motion of Apulia (Fig. 3). This caused imbrication and partial overriding by nappes of the southern parts of the North Alpine Molasse Basin, northward displacement of the Swiss North Alpine Molasse Basin and, from there, eastward propagating uplift of the entire remnant basin (starting at ca. $11 \mathrm{Ma}$ : Kuhlemann et al., 2001; Kuhlemann \& Kempf, 2002), and folding and thrusting of the Jura and Subalpine Chains during the Late Miocene (Laubscher, 1992; Sissingh, 1997, 2001; Phase 6 of Dewey et al., 1989).

\section{Tectonostratigraphic Outline of the Alpine Foreland Evolution}

\section{Alpine Foreland Basin}

This pro-wedge basin developed in response to flexural isostatic compensation and subduction of the European foreland lithosphere that was induced by overthrusting of the Apulian Microplate. It forms a zone along the Alpine orogenic belt in which sediment accumulated. Its orogenic margins are formed by the Northern and Western Alps, and it is geographically divided into a North and a West Alpine Foreland Basin (Fig. 1; Encls 1 and 2). Subsidence was driven by the load of the northwestward propagating North and West Alpine orogenic wedges and enhanced by the vertical loading effect of the basin fills on the flexed lithosphere. Through the tectonic loading of the pro-wedge foreland crust by the advancing Alpine orogenic wedge, the events that governed the Alpine phases of intraorogen deformation also affected the development of the Alpine Foreland Basin. The inception of the basin corresponded with the Late Paleocene accretion of a leading Apulian terrane to the southern European continental margin. This event initiated the closure of the last remnant oceanic basins of the western Neotethys and the final decay of the Tethyan seaway. This compressive overthrust event converted the European passive margin into an embryonic Alpine orogenic belt. It simultaneously caused flexure-induced subsidence in the proximal convergence zone and erosion-inducing uplift (bulging) of the European foreland farther away from the newly-formed, wedge-shaped orogenic zone (Allen et al., 1991; Sinclair \& Allen, 1992; Sinclair, 1997b). While the Apulian leading edge progressively overrode the European margin, flexural foreland subsidence developed generally deep-water depositional conditions for the Alpine Foredeep, the early pro-wedge foreland basin. Plate convergence and overthrusting continued to push the northern orogenic wedge over the margin. Possibly until uplift of the Alpine orogenic wedge in response to a Rupelian detachment of a subducted lithosphere slab (Sinclair, 1997a) that closed the transitional Alpine 'Pre-Molasse' Basin (Sissingh, 1997), flexure-induced subsidence no longer exceeded sediment accumulation. Instead, shallow-water deposition became predominant in the Alpine Molasse Basin, the younger foreland basin (Sissingh, 1997). Towards the end of the Cenozoic, isostatic rebound of the orogenic wedge possibly in response to another slab detachment (Andeweg \& Cloetingh, 1998) leading to decoupling of the Apulian and European plates (Mantovani et al., 1993) - occurred during reduced convergence and nappe piling. It concluded the sedimentary phase of the basin with an Alpine orogenic phase that induced widespread erosion and non-deposition. Thus, a succession of three basinal settings is distinguished for the North and West Alpine Foreland basins (Sissingh, 1997). From old to young these are:

1. Alpine Foredeep - Essentially an underfilled basin characterised by a tripartite sediment sequence of shallowmarine, basal carbonates, which are overlain by deep-water (hemi)pelagic marls and flysch. This sequence formed in response to increasing subsidence which caused accommodation space to exceed sediment supply. The contemporaneous kinematic development of the accretionary thrust-wedge was typified by relatively rapid, submarine advances towards the platform, dominantly horizontal 
motions and low exhumation rates. Consequently, limited erosional unroofing of the Alpine orogenic wedge occurred.

2. Alpine 'Pre-Molasse' Basin - Transitional, underfilled to filled basin with a sediment fill of deep-water flysch, shallowwater carbonates and non-classical molasse in broadly comparable proportions. Thrust-wedge loading, thickening, exhumation and unroofing increased, as the movement of the Alpine thrust front decreased.

3. Alpine Molasse Basin - Mainly filled to overfilled basin characterised by shallow-water molasse. Thrust-wedge loading and thickening occurred under largely subaerial conditions, as the advancing thrust-front slowed down. Consequently, Alpine thrust-wedge erosion was substantial and induced additional subsidence of the basin in response to sediment loading.

\section{North Alpine Foreland Basin}

The lithostratigraphy and sequence stratigraphic subdivisions of the North Alpine Foreland Basin are shown in the Figures 5 to 7 (see Sissingh (1997) for details). The tectonosedimentary history of the basin began with deposition of Thanetian and younger marine strata on top of a widespread unconformity. This hiatus developed in relation to uplift and erosion that was induced by compressional folding of the crust in front of the advancing incipient Alpine thrust belt. Accumulation in the marine North Alpine Foredeep continued until about the Bartonian-Priabonian transition, when the North Alpine 'Pre-Molasse' Basin formed. Younger Tertiary deposits of the successive North Alpine Molasse Basin are commonly classified into the following general sedimentary series (Figs 5 to 7 ) which partly overlap each other in time (e.g. Kempf et al., 1999; Strunck \& Matter, 2002):

1. Lower Marine Molasse (essentially Rupelian)

2. Lower Freshwater Molasse (Chattian-Aquitanian)

3. Upper Marine Molasse (Burdigalian)

4. Upper Freshwater Molasse (Langhian-early Tortonian).

Similar to the older fill of the North Alpine Foreland Basin, the accumulation of this four-fold succession of continental to marine sequences, is also directly linked to the tectonics of the evolving Alpine orogenic wedge. Deposition came to an end due to basin-wide uplift in the Tortonian. Especially the post-Middle Eocene sequence boundaries formed in response to changes in eustatic sea level onto which tectonic pulses in the adjacent Alpine orogen were superimposed (Figs 8 to 10; see Sissingh (1997) for discussion).

\section{West Alpine Foreland Basin}

The lithostratigraphy and the sequence stratigraphic interpretations of the West Alpine Foreland Basin, the coeval Manosque-Forcalquier Basin and post-Oligocene Cucuron-
Valensole Basin are summarised in Fig. 11 (see Sissingh (2001) for details). Generally, the development of the West Alpine Foredeep and 'Pre-Molasse' basins resembled that of their northern equivalents. The preserved fill of the West Molasse Basin consists of two major sedimentary series (Fig. 11):

1. Continental-Marine Series (Rupelian)

2. Continental Series (Chattian).

These series are separated by a hiatus which is related to the major fall in eustatic sea level of the mid-Oligocene and to coeval tectonic uplift and continentalisation of the basin. Post-Oligocene uplift terminated deposition and caused erosion of the Upper Oligocene. In general, the basin fill of the southeastern West Alpine Foreland records a Late EocenePliocene succession of short-duration tectonic events, which are often represented by an unconformable sequence boundary (Figs 8 and 11; see Sissingh (1997) for discussion).

\section{European Cenozoic Rift System}

Cross-cutting the regional Variscan structural grain this intraplate graben system extends with a variable, but overall N-S orientation from the southern North Sea Basin and southern North German Basin across the West European Platform to the Iberian Meseta in the westernmost Mediterranean Basin. Farther to the south, the rift can be traced till in the Atlantic (Ziegler, 1994). Its position is thought to be controlled by pre-existing zones of weakness in the Variscan basement. From north to south it can be divided into the following principal segments (Figs 1 and 2; Encls 1 and 2):

1. Northern European Cenozoic Rift Segment - Including the NNE-SSW trending Upper Rhine Graben which bifurcates at its northern end, forming the Rhenish Triple Junction at the Rhenish Massif. Its eastern branch leads to the NNESSW striking Hessen Depression, whereas the western branch forms the NW-SE trending 'Middle Rhine Graben' (Neuwied Basin) and the NW-SE striking Lower Rhine Graben that comprises the Lower Rhine Embayment at the Rhenish Massif (Sissingh, 2003a).

2. Rhine-Saône Transform Zone - A sinistral, NE-SW striking transverse fault system characterised by a dense pattern of shear fractures and strike-slip faults (Lacombe et al., 1993).

3. Southern European Cenozoic Rift Segment - Consisting of the almost N-S trending Rhône Graben (dominated by the Bresse and Valence grabens; Sissingh, 2001), the relatively wide and complex Gulf of Lions with narrow and elongate, NESW trending grabens (Séranne, 1999, Guennoc et al., 2000) and the NE-SW striking Valencia Trough (discussed below).

4. Mediterranean-Atlantic Volcanic Chain - Includes the riftrelated, alkaline volcanic chain of latest Miocene and PlioPleistocene age that connects the Alboran Basin with the Cape Verde Islands via the Rif and Atlas mountain ranges of northern Africa (Ziegler, 1994). 


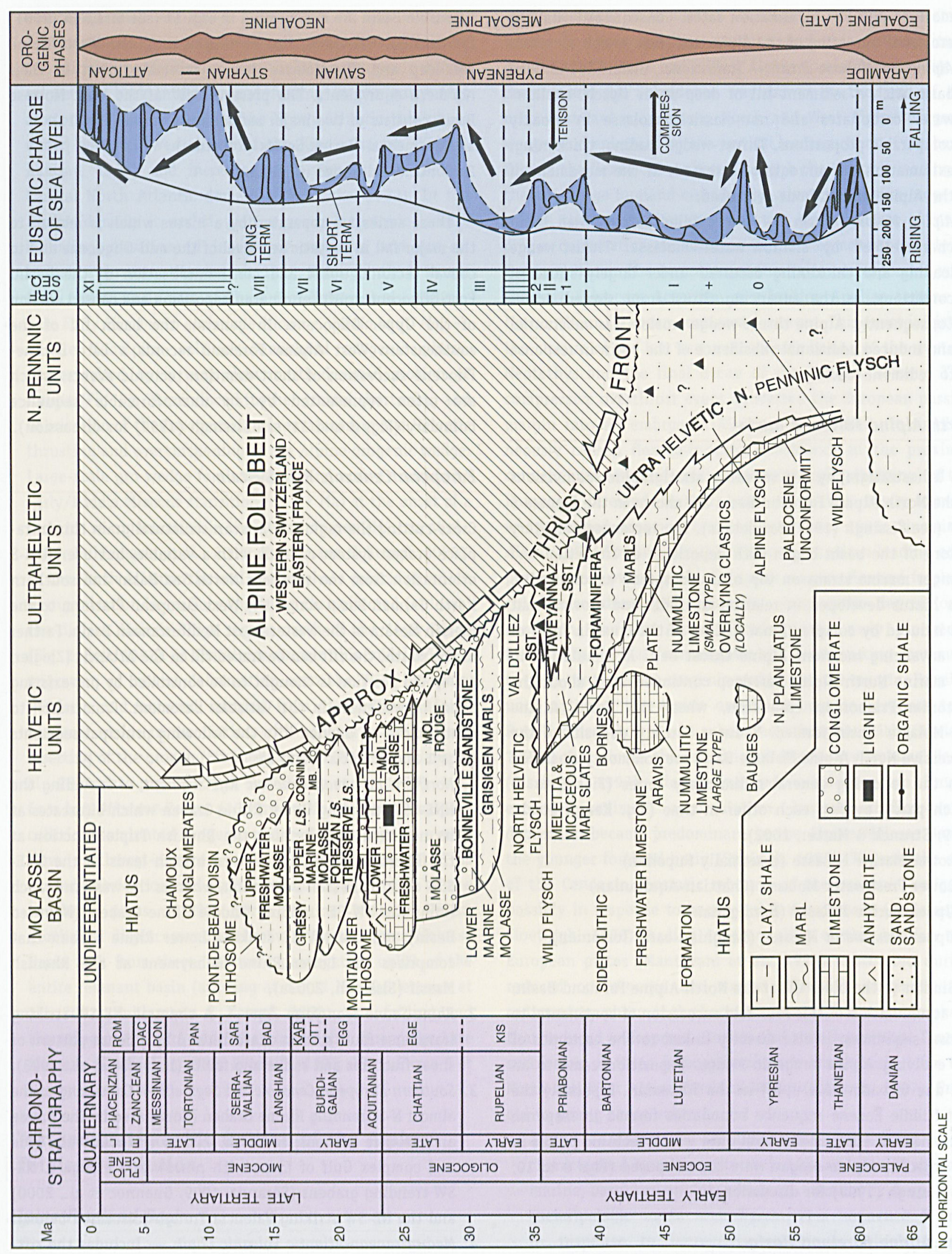

Fig. 5. Lithostratigraphic diagram and sequence stratigraphic interpretation for the western part of the North Alpine Foreland Basin (from Sissingh, 1997). $K I S=$ Kiserian $; E G E=$ Egerian $; E G G=$ Eggerian; $O T T=$ Ottnangian $; K A R=$ Karpatian $; B A D=$ Badenian; $S A R=$ Sarmatian; $P A N=P a n n o n i a n ;$ $P O N=$ Pontian; $D A C=$ Dacian; $R O M=$ Romanian. Fluctuations in eustatic sea level are interpreted to be related to compressional and tensional changes in intra-plate stress (after Cloetingh, 1986). Arrows indicate second-order stress-field trends. 


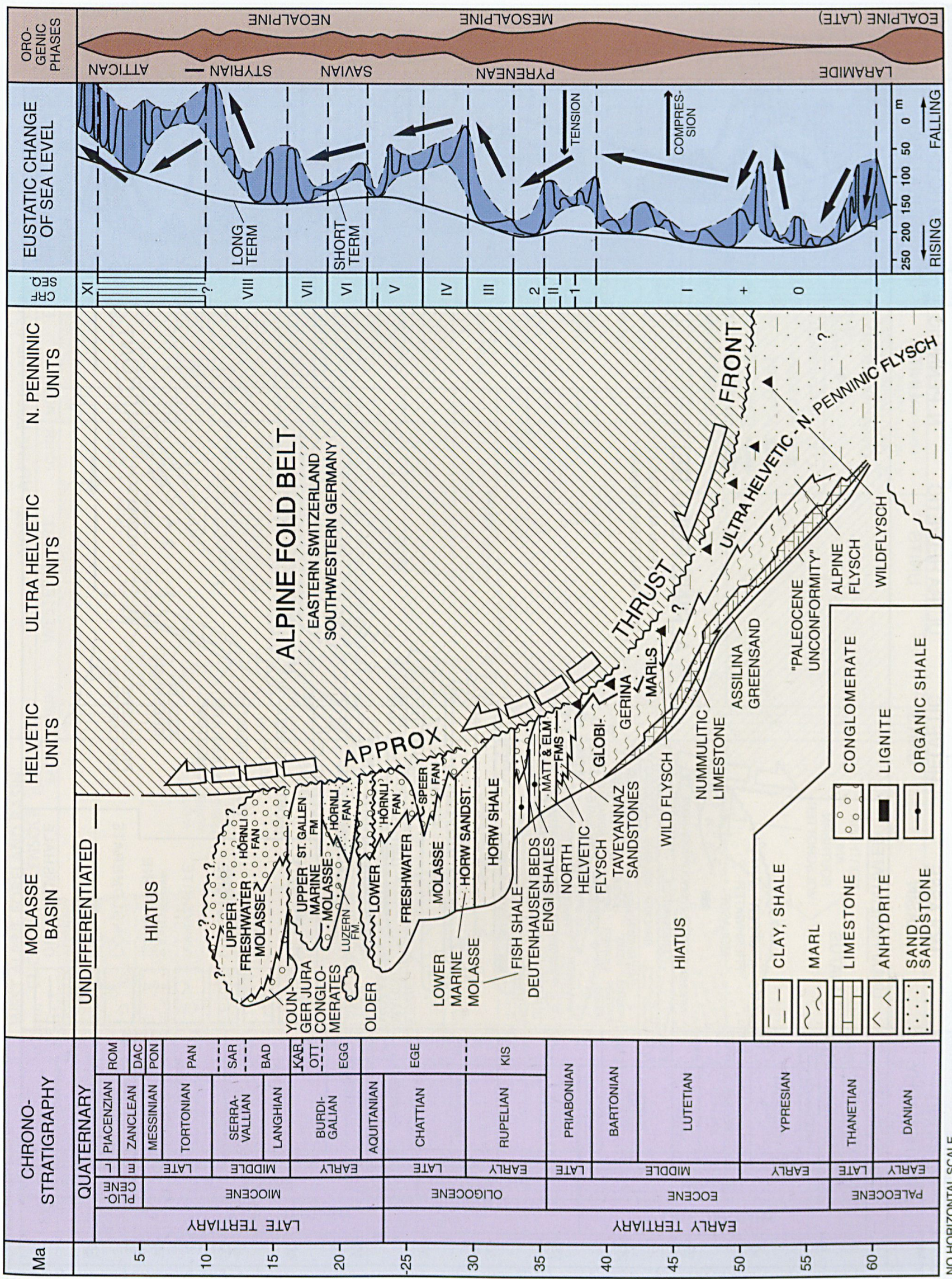

Fig. 6. Lithostratigraphic diagram and sequence stratigraphic interpretation for the central part of the North Alpine Foreland Basin (from Sissingh, 1997; modified after Schlunegger et al., 1996 and Kempf \& Matter, 1999; see Fig. 5 for explanation). 


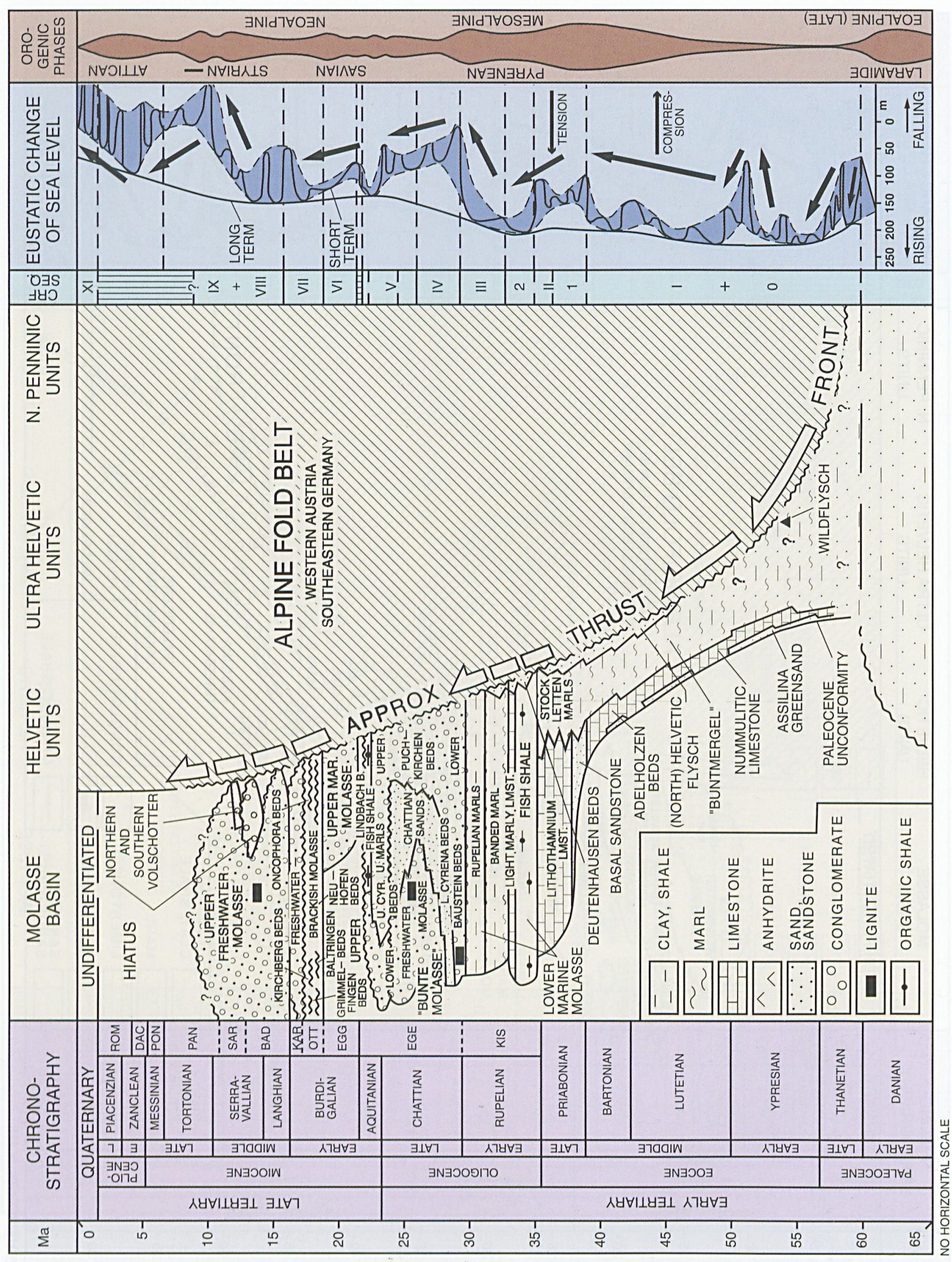

Fig. 7. Lithostratigraphic diagram and sequence stratigraphic interpretation for the eastern part of the North Alpine Foreland Basin (from Sissingh, 1997; see also Fig. 5). 


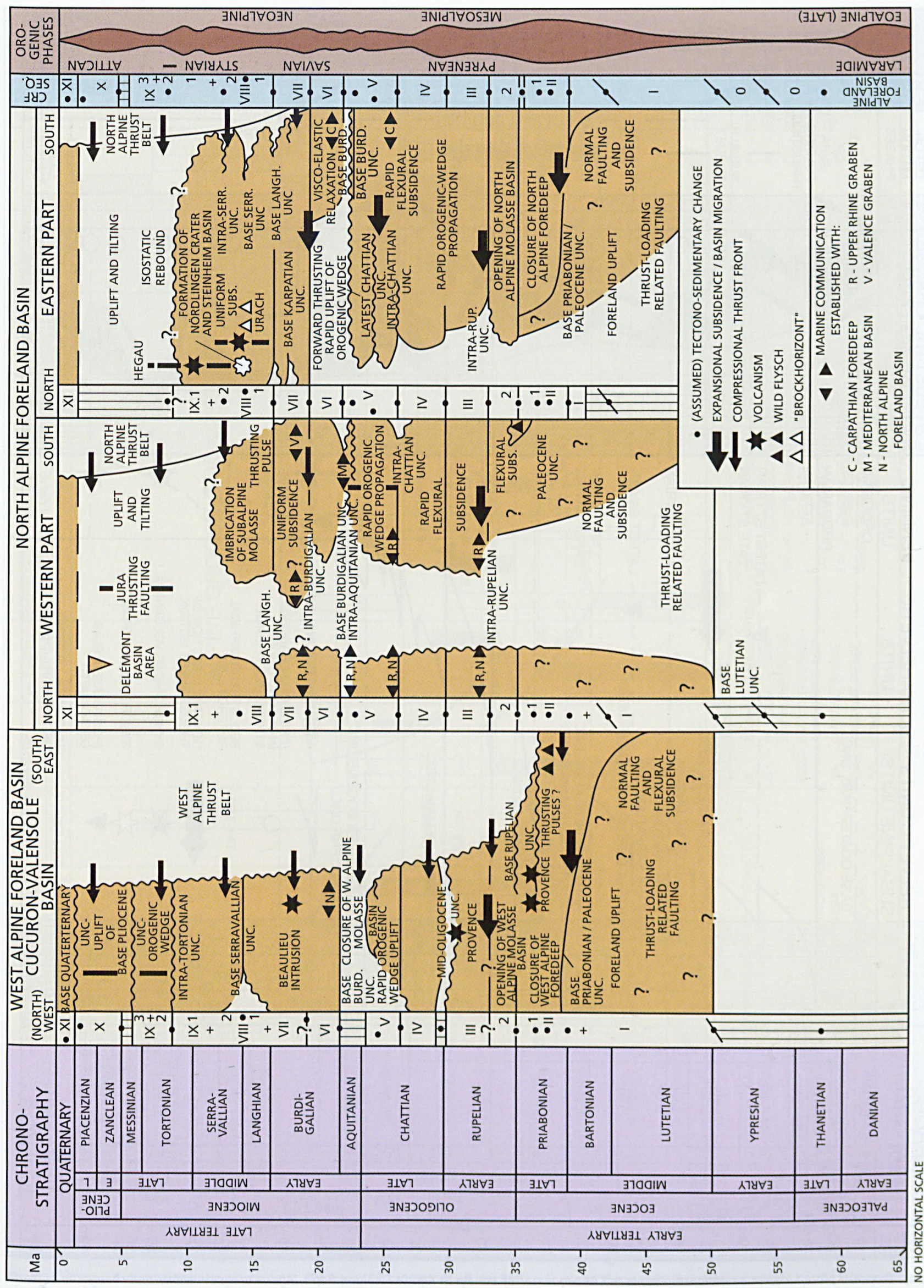

Fig. 8. Structural developments and tectonosedimentary changes in deposition of the North and West Alpine Foreland basins. 


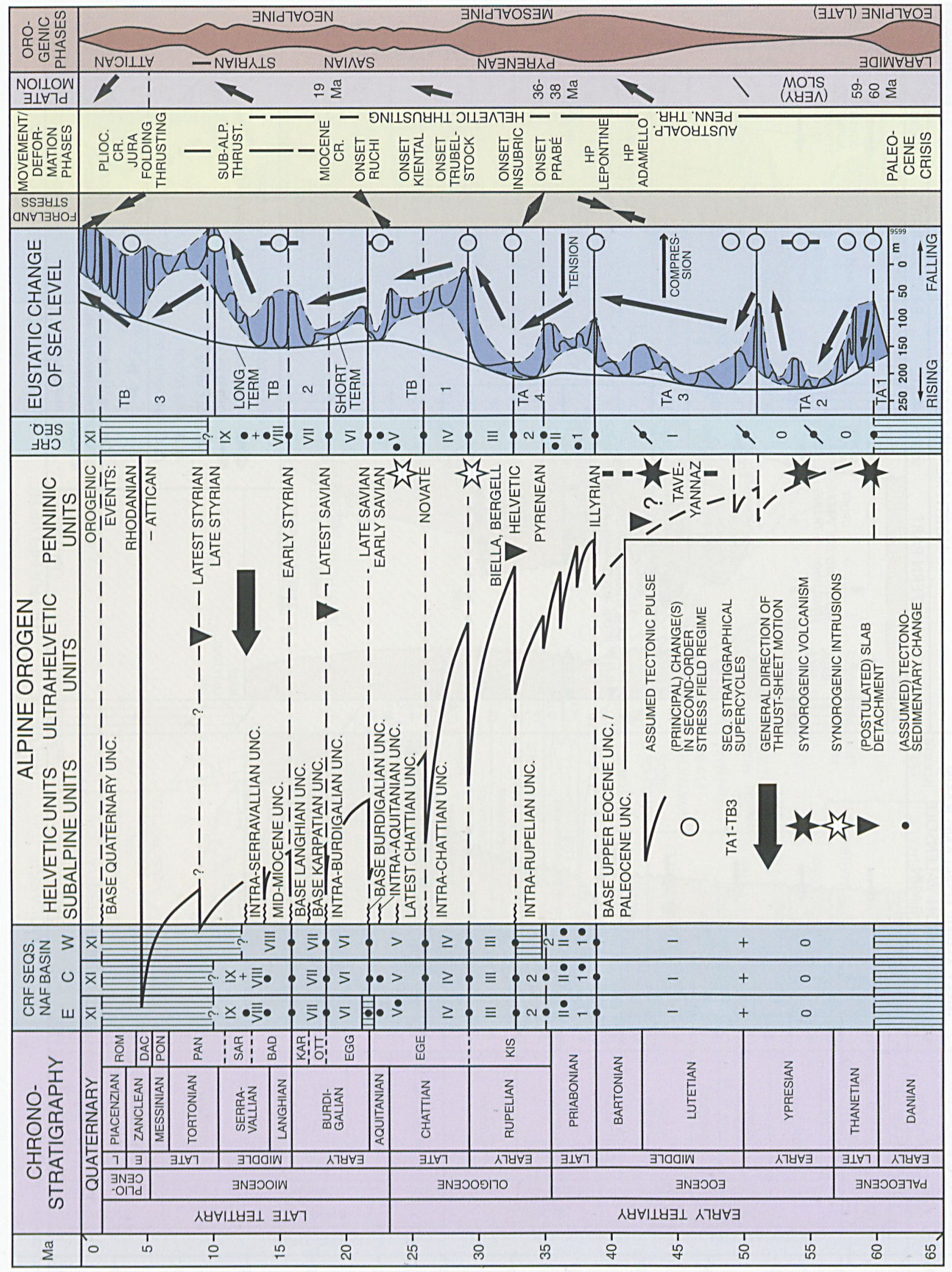

Fig. 9. Proposed plate-kinematic relationship between CRF sequences of the North Alpine Foreland Basin, Alpine orogenic events and changes in eustatic sea level (modified after Sissingh, 1997). 


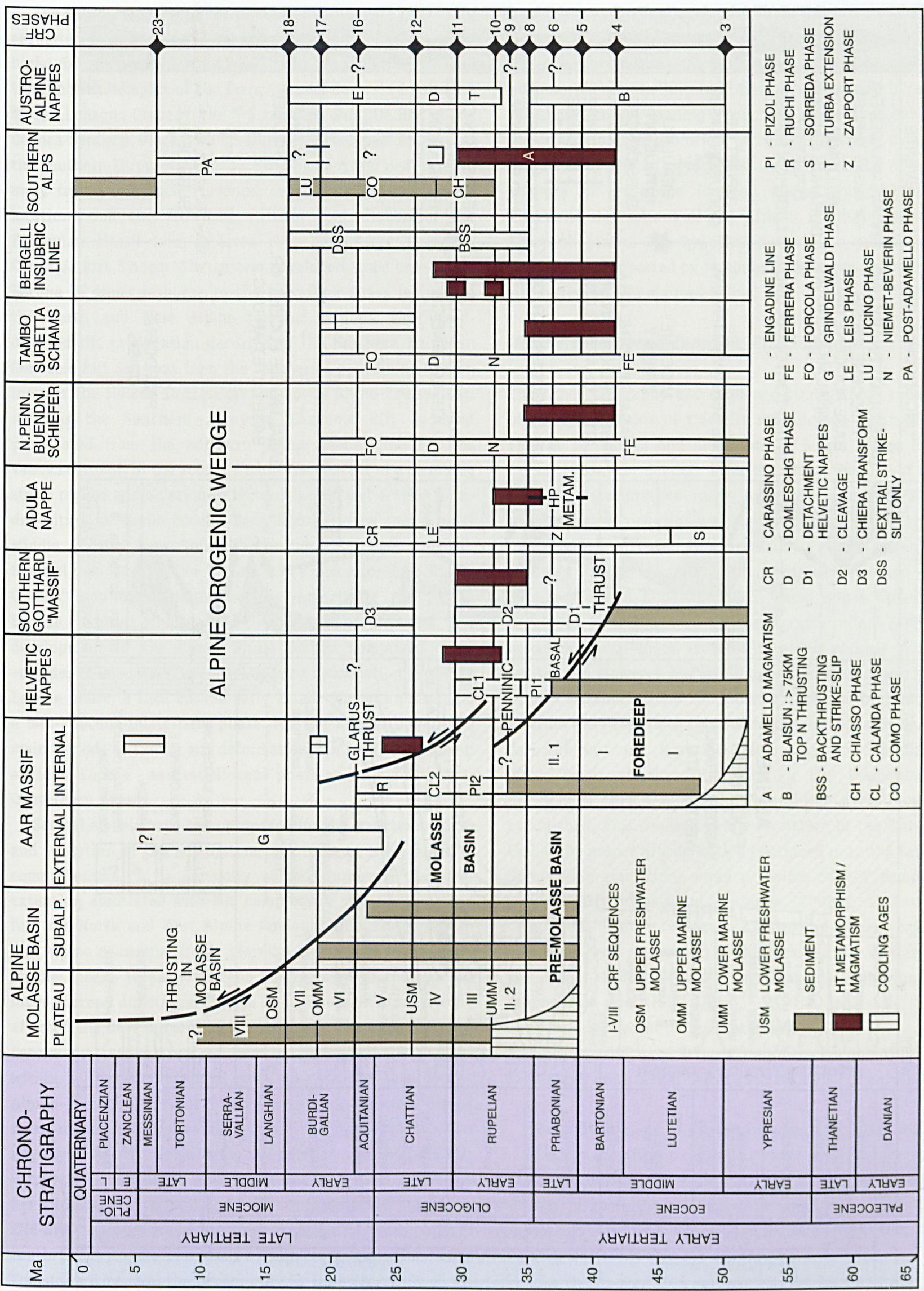

Fig. 10. Proposed plate-kinematic relationship between CRF sequences of the Alpine Foreland Basin and deformation phases of the Alpine orogenic wedge (after Schmid et al., 1997) and correlation with CRF phases of the North and West Alpine Foreland domains (see Fig. 23 for explanation). 


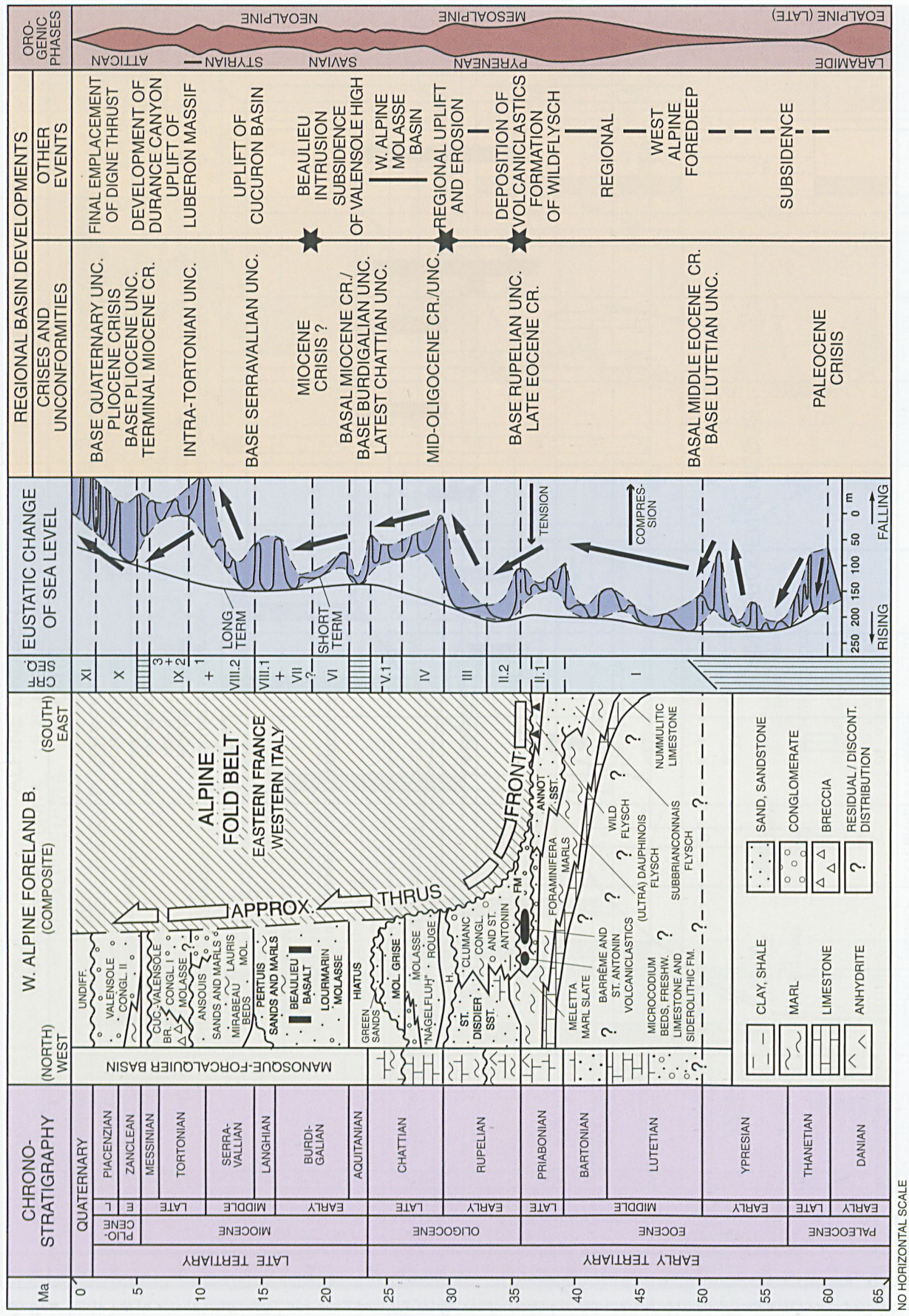

Fig. 11. Lithostratigraphic diagram and sequence stratigraphic interpretation for the southeastern West Alpine Foreland (from Sissingh, 2001). 
The rift segments comprise (sub)basins which are frequently separated from each other by ENE-WSW to NNE-SSW trending highs. In addition to the four-fold main rift structure, the N-S trending rift complex of the French Massif Central (dominated by the Limagne Graben), the N-S trending Sardinia Rift of the Corsica-Sardinia Block (which initially developed as part of the Southern European Cenozoic Rift Segment and next rotated away from the French Provençal coastal area to its present location) and the ENE-WSW striking Eger Graben of the Bohemian Massif form isolated elements of the European Cenozoic Rift System. The system developed since the Middle Eocene in direct response to the prevailing stress regimes of the North and West Alpine foreland regions. Northwarddirected rift propagation occurred in the Northern European Cenozoic Rift Segment from the southern Upper Rhine Graben towards the Hessen Depression and Lower Rhine Embayment, whereas the Southern European Cenozoic Rift Segment propagated from the northern Rhône Graben towards the Valencia Trough in the south. Within the context of a changing stress regime and a period of tectonic uplift and erosion/nondeposition, a Middle Eocene 'Early Rhine Graben' and a postMiddle Eocene 'Late Rhine Graben' may be distinguished. Similarly, an 'Early Rhône Graben' and a successor 'Late Rhône Graben' may be distinguished for respectively the Middle Eocene - earliest Miocene and the later Cenozoic period. The development of the Upper Rhine Graben comprised three episodes of low-strain/low-displacement deformation: a Middle Eocene phase, a Late Eocene-early Middle Miocene phase and a mid-Pliocene-Quaternary phase. For the Rhône Graben two main periods of similar rift deformation can be distinguished: a Middle Eocene - earliest Miocene phase and a mid-PlioceneQuaternary phase.

Several models have been proposed for the structural origin and evolution of the rift system; but none of them is really comprehensive. It is generally agreed, however, that E-W extension associated with $\mathrm{N}$-S compressive stresses projected into the North and West Alpine forelands from the Pyrenean and Alpine collisional fronts played a crucial role in the early Middle Eocene to Early Miocene development of the rift. An intra-Miocene directional change in compression also strongly affected the development of the structure. The initial, Middle Eocene compressive stress regime would have resulted in grabens within a Pyrenean tensional gash, whereas the Late Eocene Alpino-Pyrenean and the Oligocene to Early Miocene Alpine stress regime would have re-activated and further shaped the rift system. In keeping with such a plate-kinematic perspective, the Rhine and Bresse grabens have previously been interpreted as pull-apart depressions linked by major, ENE-SWS to NE-SW trending transcurrent faults. From north to south these are the Metz-Mainz Fault Zone, the Rhine-Saône Transform Zone, and the Cévennes Fault Zone (Fig. 2; Encl. 2). Similarly transverse strike-slip fault zones delimit rhombshaped intragraben subbasins (Chorowicz \& Deffontaines, 1993;
Sissingh, 1998, 2001). In addition to the effects of the farfield stress regimes, other mechanisms, such as mechanical stretching of the lithosphere in response to active mantle and asthenosphere upwelling and lithosphere flexuring in response to Alpine thrust loading (Bois, 1993) were probably also important for the evolution of the rift system. 0verall the evolution of the rift proceeded under influence of episodic changes in pro-wedge foreland stress regimes related to kinematic interactions of the African, Apulian, Iberian and European plates. The hypothesis of such a punctuated rift evolution is supported by tectonostratigraphic analyses of the rift system as summarised below.

\section{Northern European Cenozoic Rift Segment}

The lithostratigraphy and sequence stratigraphic subdivision of the main basins of this rift segment are summarised on Figures 12 and 13 and Enclosures 3, 5 and 7 (see Sissingh $(1998,2003 a)$ for details). Prior to rifting, the area of the rift segment was shortened during Late Cretaceous and Paleogene phases of basin inversion and upwarping (Ziegler, 1994; Ziegler et al., 1995). After these compressional events, Lutetian and probably (some) Bartonian sediments accumulated in the land-locked and fault-controlled 'Early Rhine Graben' that developed in response to impure, transtensional E-W rifting associated with block movements along oblique strike-slip fault zones. However, the initial graben formation was induced by N-S striking Alpine compression (Schumacher, 2002). Its position was determined by re-activation of crustal-scale PermoCarboniferous and Mesozoic fracture systems (Schumacher, 2002; Dèzes et al., 2004). During the Priabonian-early Rupelian, a pure, E-W striking extensional stress regime was established. This resulted in the formation of the 'Late Rhine Graben' by proper rifting. Rifting continued until the LanghianSerravallian transition, when a regime of E-W compression was probably established (Sissingh, 2003a). In turn, this compression was replaced by second-phase extension (combined with strike-slip) in the Pliocene. The Tertiary fill of the Upper Rhine Graben comprises the following major sedimentary series (Fig. 12):

1. Older Continental Series (Lutetian)

2. Continental-Marine Series (Priabonian-Langhian)

3. Younger Continental Series (Serravallian-Piacenzian).

The start and end of deposition of each of these series was marked by significant tectonic events, which correspond to the onset and end of the different phases of graben formation. During graben formation, intra-graben deposition was repeatedly affected by short-lived tectonic events (Fig. 14; see Sissingh (1998, 2003a) for discussion).

Like the Upper Rhine Graben area, the region of the Hessen Depression was subjected to pre-rift uplift and erosion. E-W striking rifting propagated from the Upper Rhine Graben into 


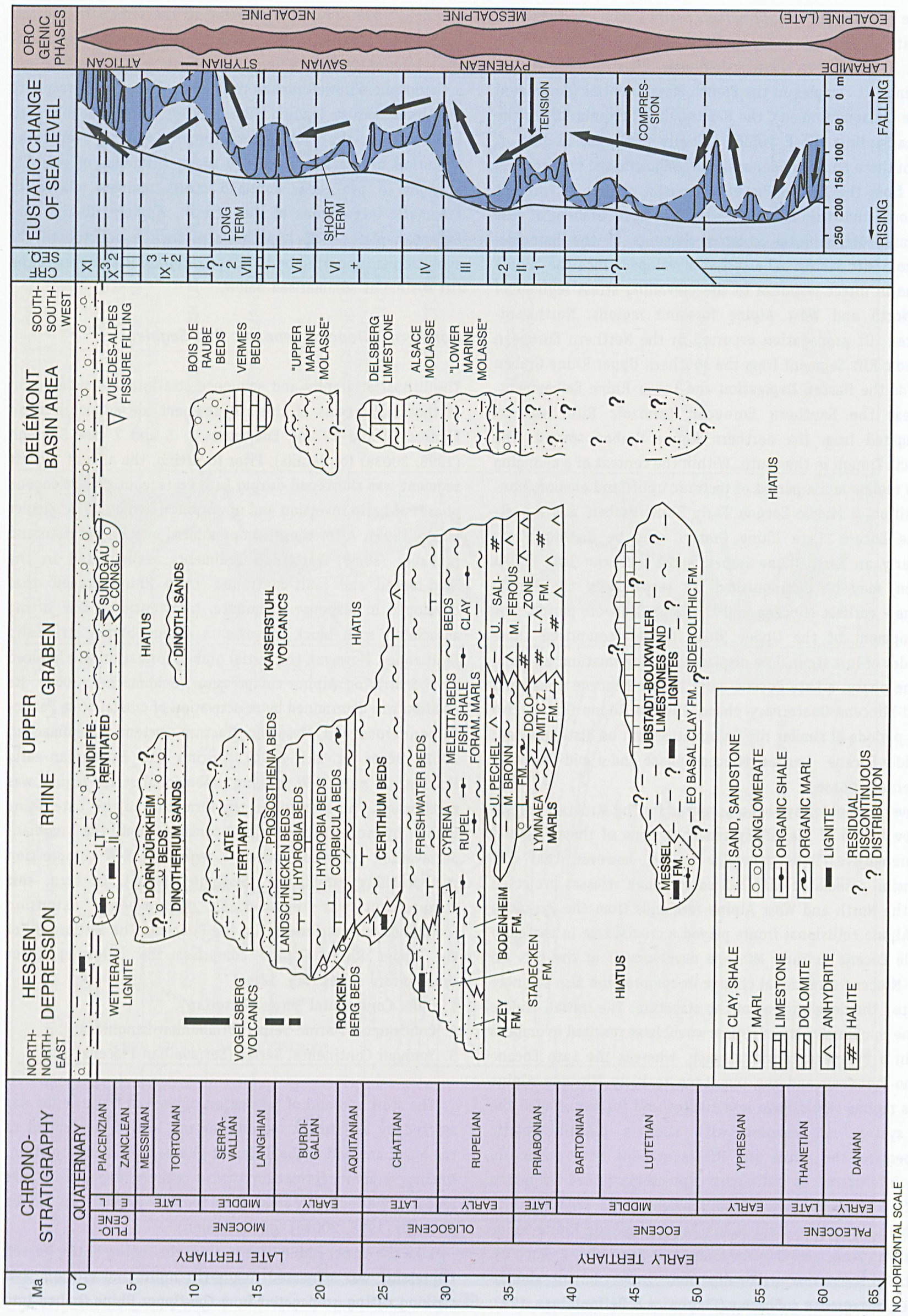


the Hessen Depression during the Lutetian. It persisted in this basin until the Langhian, when widespread uplift occurred and volcanism became prevalent. The pre-volcanic syn-rift fill of the graben can be divided into three major sedimentary series (Fig. 13):

1. Older Continental Series (late Lutetian-early Rupelian)

2. Marine Series (late Rupelian-early Chattian)

3. Younger Continental Series (late Chattian-Burdigalian).

Deposition of these series was again controlled by tectonics. The depositional history of the rift basin was punctuated by an episodic succession of brief tectonic events including four pre-volcanic periods of deposition, which are bounded by erosional/non-depositional hiatuses (Fig. 14; see Sissingh (1998, 2003a) for discussion).

In the Lower Rhine Embayment, the third major basin of the Rhenish Triple Junction, syn-rift deposition occurred from the Priabonian-Rupelian transition to the Recent. The initial, SW-NW trending rifting occurred in combination with re-activation of pre-existing faults that responded to NNW-SSE directed compression. The main phase of rifting lasted from the Chattian until the mid-Aquitanian. The Tertiary of the Lower Rhine Embayment is subdivided into the following, partly unconformity-bounded sedimentary series (Fig. 13):

1. Marine Series (Rupelian)

2. Older Continental - Marine Series (Chattian-Aquitanian)

3. Younger Continental - Marine Series (Burdigalian-Messinian)

4. Continental Series (Zanclean-Piacenzian).

This succession reflects a complete retreat of the sea from the basin. On the whole, this fundamental change in depositional setting is probably related to episodicallyprogressing, relative tectonic uplift of the Rhenish Massif, and to longer-term lowering of the global sea level (Fig. 14; see Sissingh (2003a) for discussion).

In summary, the structural evolution of the composite Northern European Cenozoic Rift Segment was governed by diachronous, syn-sedimentary intra-plate rifting associated with volcanic activity and uplift of the Rhenish Massif. In addition to fault-controlled basin subsidence and tectonomagmatically induced uplift and denudation of the adjacent massif, the depositional history of the graben system was also influenced by fluctuations in sea level. Tectonic and magmatic events intermittently affected all three main grabens of the Rhenish Triple Junction (Fig. 14).

\section{Eger Graben}

The lithostratigraphy and sequence stratigraphic interpretation of the small, intra-massif Eger Graben (Encl. 2) is shown in Fig. 15. Polyphase tectonic development of the five component basins resulted in accumulation of fluvial and lignite-bearing lacustrine deposits intercalated with volcanic and pyroclastic horizons (see Kasiński (1991) for details). Three main sedimentary series occur (Fig. 15):

1. Older Continental Series (Bartonian-Rupelian)

2. Intermediate Continental Series (Chattian-Serravallian)

3. Younger Continental Series (Zanclean-Piacenzian).

The pre-Pliocene basin fill comprises a number of 'megacyclothems' which developed during intermittent volcanic activity. They match (in general) the sequence stratigraphic subdivision (Fig. 15). This continental sedimentary series represents a succession of rifting phases and tectonovolcanic episodes during which rift-bounding faults were re-activated and graben subsidence increased (Kasiński, 1991).

\section{Southern European Cenozoic Rift Segment}

The lithostratigraphy and sequence stratigraphic succession of the Rhône Graben, which corresponds to the northern half of the Southern European Cenozoic Rift Segment, are shown in the Figures 16 and 17 and the Enclosures 4, 6 and 8 (see Sissingh (1998, 2001) for details). Stratigraphic features of the Mediterranean part of the rift are discussed below. In response to N-S Pyrénéo-Provençal compression, intricate rifting combined with strike-slip faulting began in the northern Rhône Graben area (Bresse Graben and ?Valence Basin) around the Ypresian-Lutetian transition. The rift propagated southward during the later Eocene and the Oligocene, through tensional and transtensional re-activation of crustal-scale Permo-Carboniferous and Mesozoic fracture systems (Dèzes et al., 2004). As in the Upper Rhine Graben, the main rifting occurred during the Priabonian and early Rupelian. E-W directed extension continued until Aquitanian time, when it was replaced by NE-SW trending compression related to the westward advancing Western Alps, until resumption of E-W extension in the earliest Pliocene. Three Tertiary sedimentary series are distinguished in the Rhône Graben (Figs 16 and 17): 1. Older Continental - Marine Series (Lutetian-Aquitanian)

2. Intermediate Continental - Marine Series (BurdigalianMessinian)

3. Younger Continental - Marine Series (Zanclean-Piacenzian).

This threefold subdivision is correlative with the syn-rift stage of the 'Early Rhône Graben' and the post-rift and final syn-rift stages of the 'Late Rhône Graben'. The sequence stratigraphic successions reflect a series of tectonic phases (Fig. 18; see Sissingh, 2001 for discussion), which can be correlated with the Late Eocene-Pliocene record of palaeostress changes determined for the Provence (Fig. 19).

\section{Limagne Graben}

The N-S trending Limagne Graben is situated above a similarly $\mathrm{N}-\mathrm{S}$ oriented Loire Dome, a local uplift of the Moho (up to a 


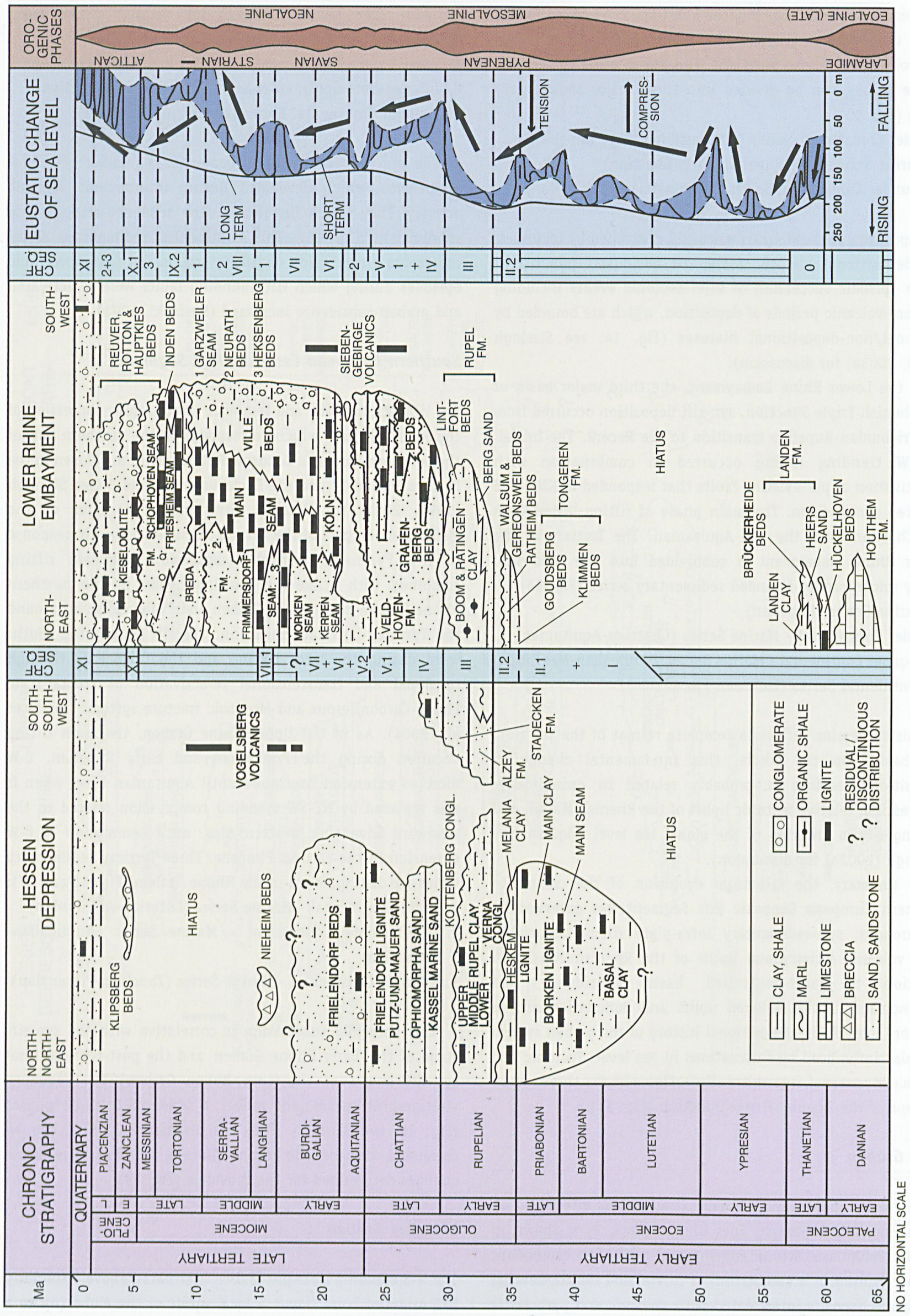




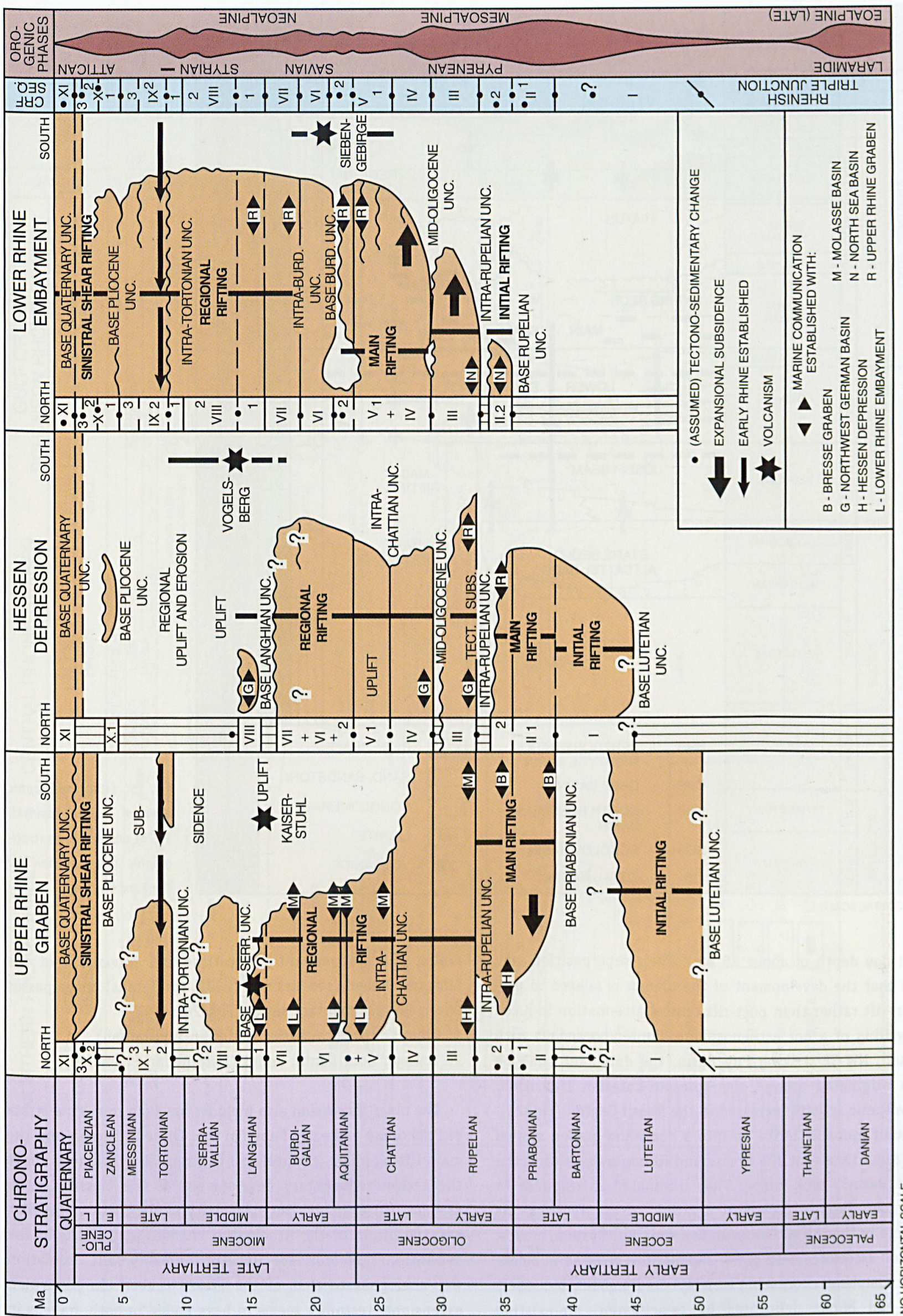

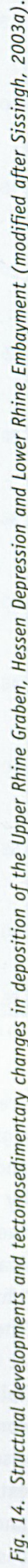




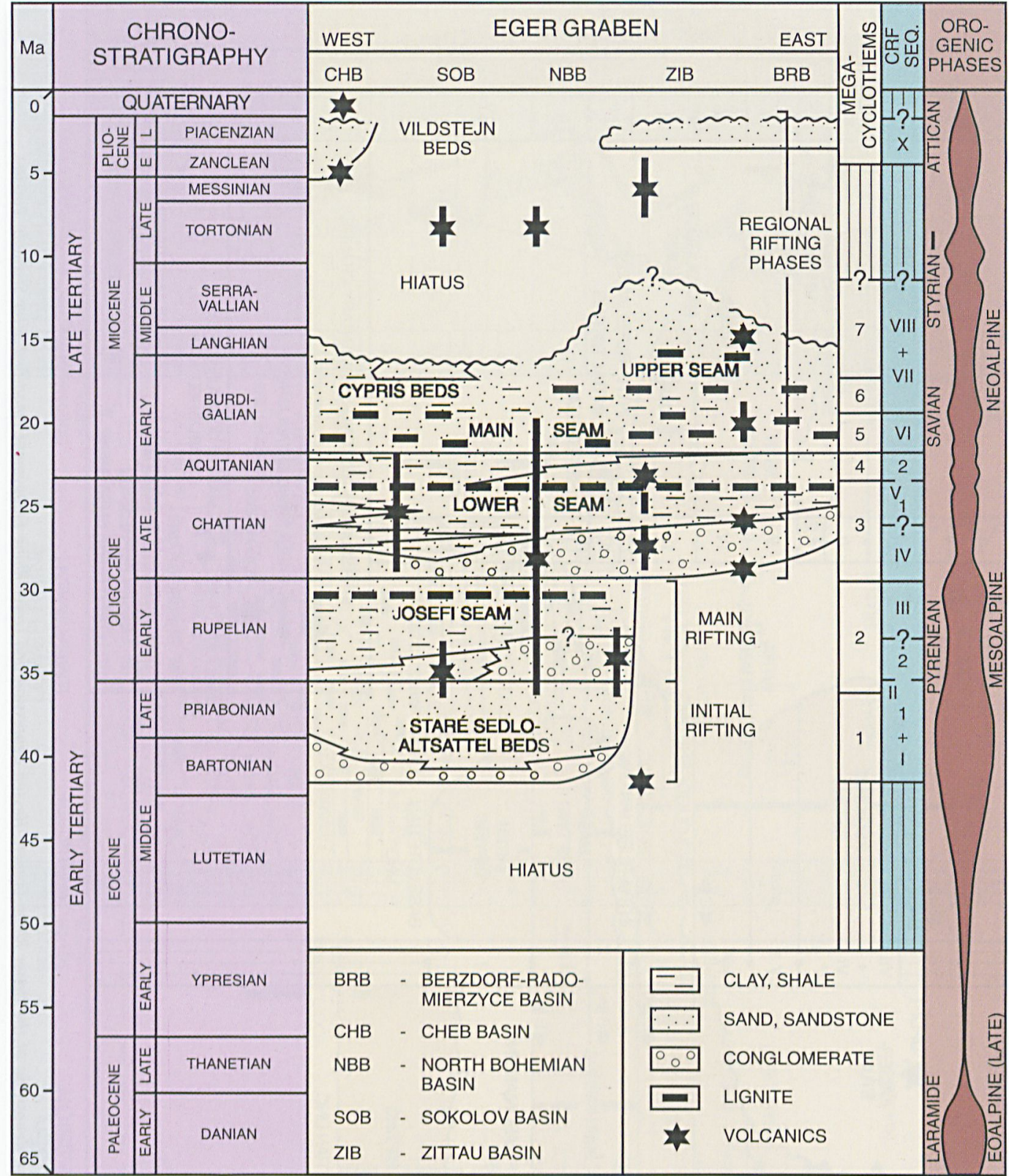

NO HORIZONTAL SCALE present-day depth of about $25 \mathrm{~km}$ ). Their superposition may signify that the development of the graben is related to preand syn-rift rather than post-rift crustal attenuation induced by upwelling of a hot asthenosphere. Contemporaneous with the small, NW-SE striking Puy Basin, the dominant Limagne Graben originated around the Ypresian-Lutetian transition, while volcanic activity increased in the Massif Central (Fig. 20). The massif probably broke up into a horst-and-graben system at the same time that the Bresse and Rhine grabens (and the Valence Basin?) took shape. They originated in response to comparable Pyrénéo-Provençal tectonic stress regimes. As elsewhere in the initial European Cenozoic Rift System, crustal extension associated with strike-slip motions resulted in blockfaulted complexes comprising variably-sized grabens, pull-apart basins and horsts delineated by re-activated, pre-existing faults. The predominantly lacustrine and fluvial fill of the Limagne Graben (see Sissingh (2001) for details) encompasses two major sedimentary series (Fig. 20):

1. Older Continental Series (Lutetian-Aquitanian)

2. Younger Continental Series (Burdigalian-Picenzian).

The older succession also includes brackish to marine strata of Priabonian and early Rupelian age. These beds represent the main rifting phase in the Massif Central. Little is known about the tectonosedimentary development of the Massif Central grabens. For example, the episodicity of the basin subsidence and the origin of the lithological changes and breaks of the depositional records are unclear. Probably, rift formation was analogous to that of the Rhône Graben. In particular, extensional tectonics seems to have ended in both grabens in 


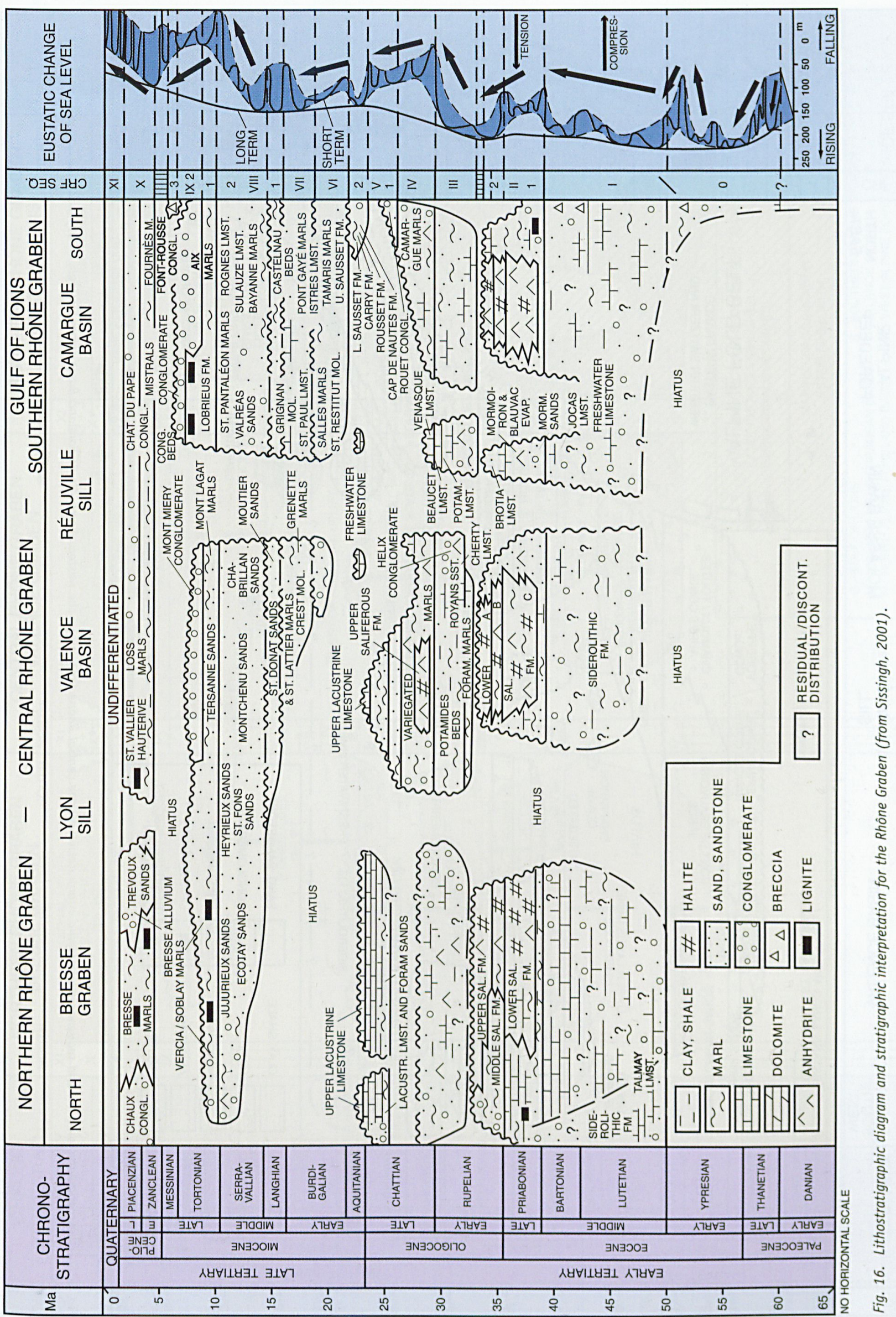




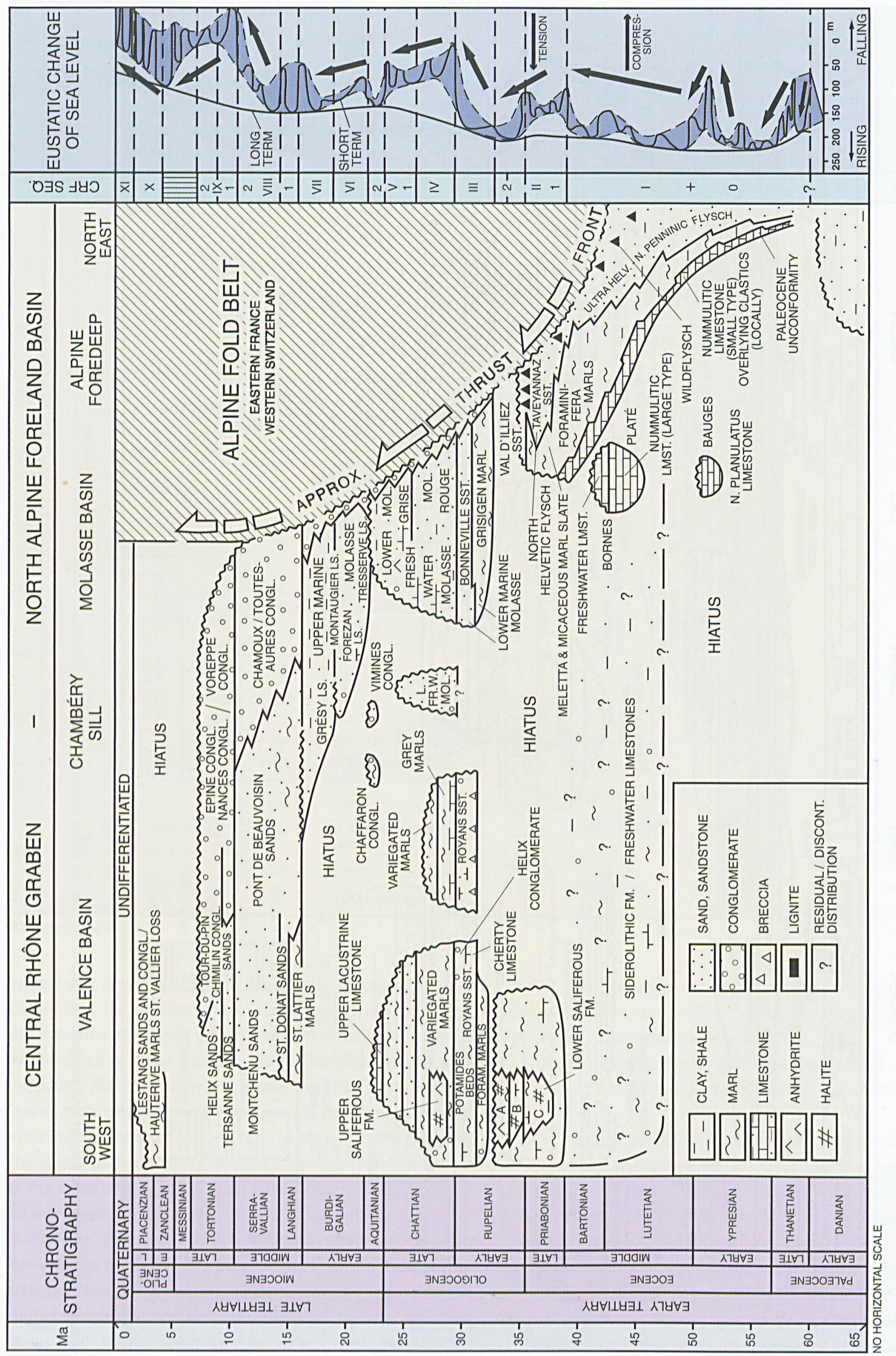




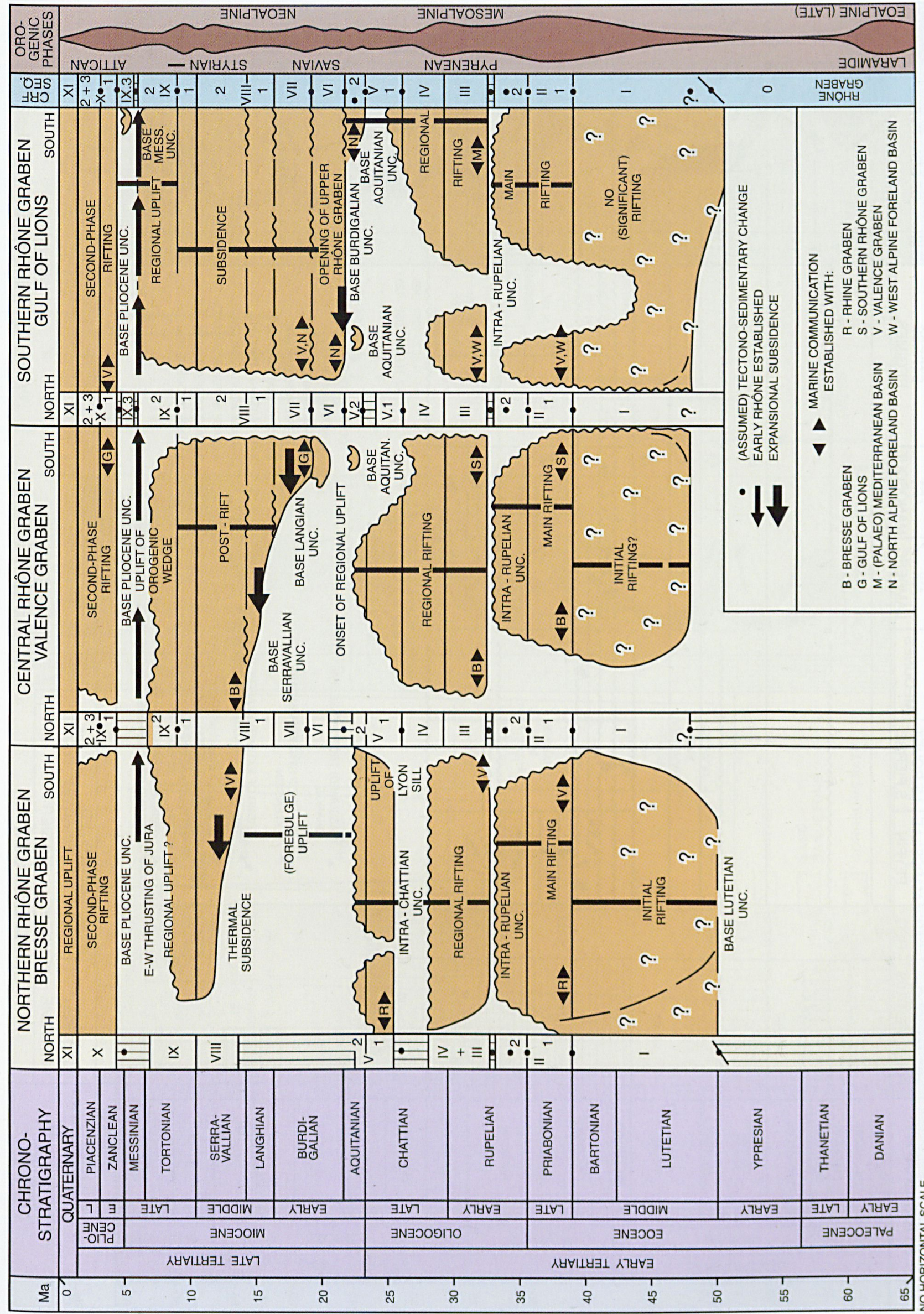




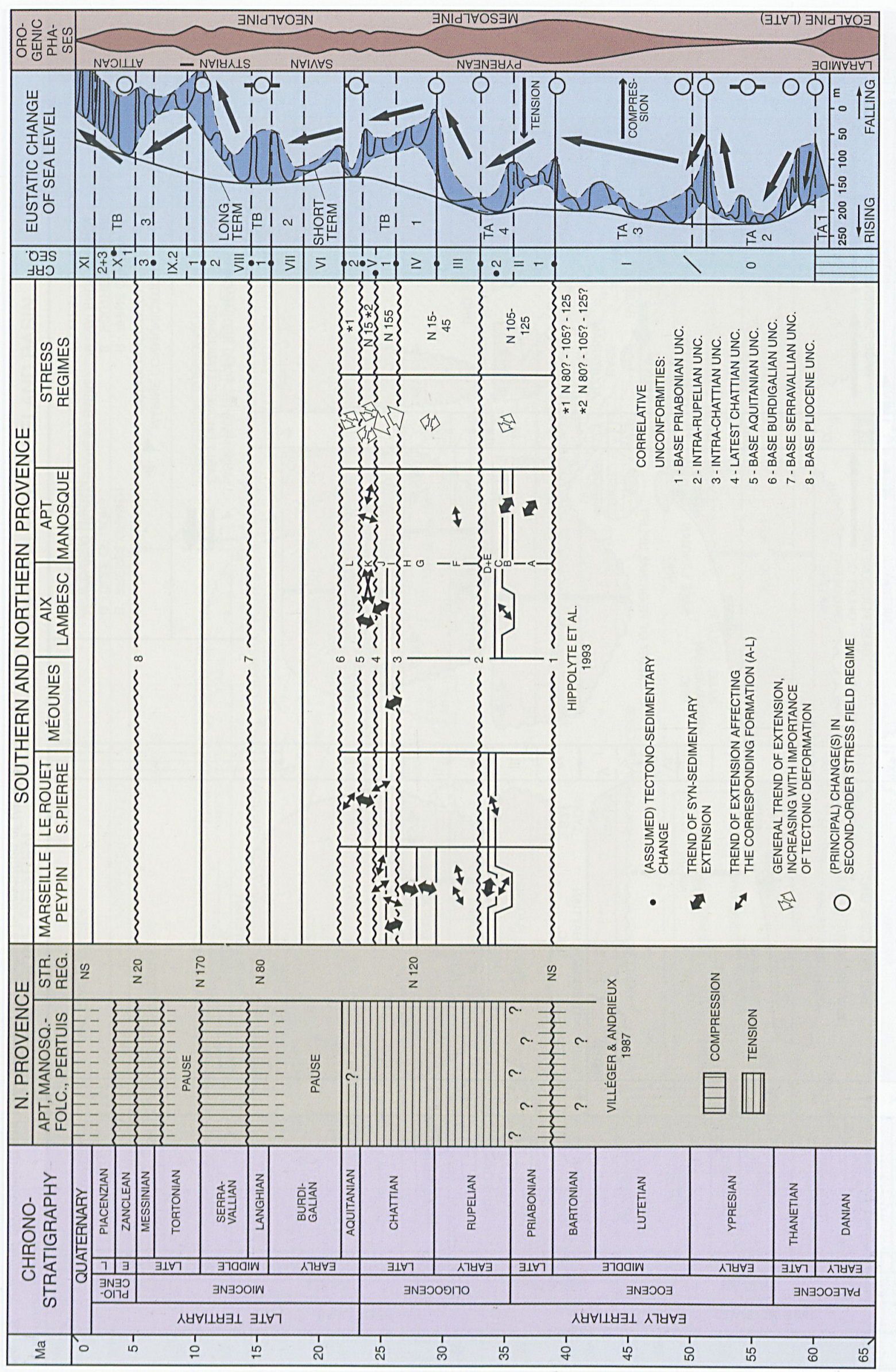

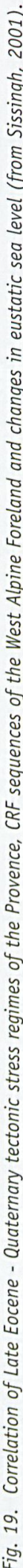




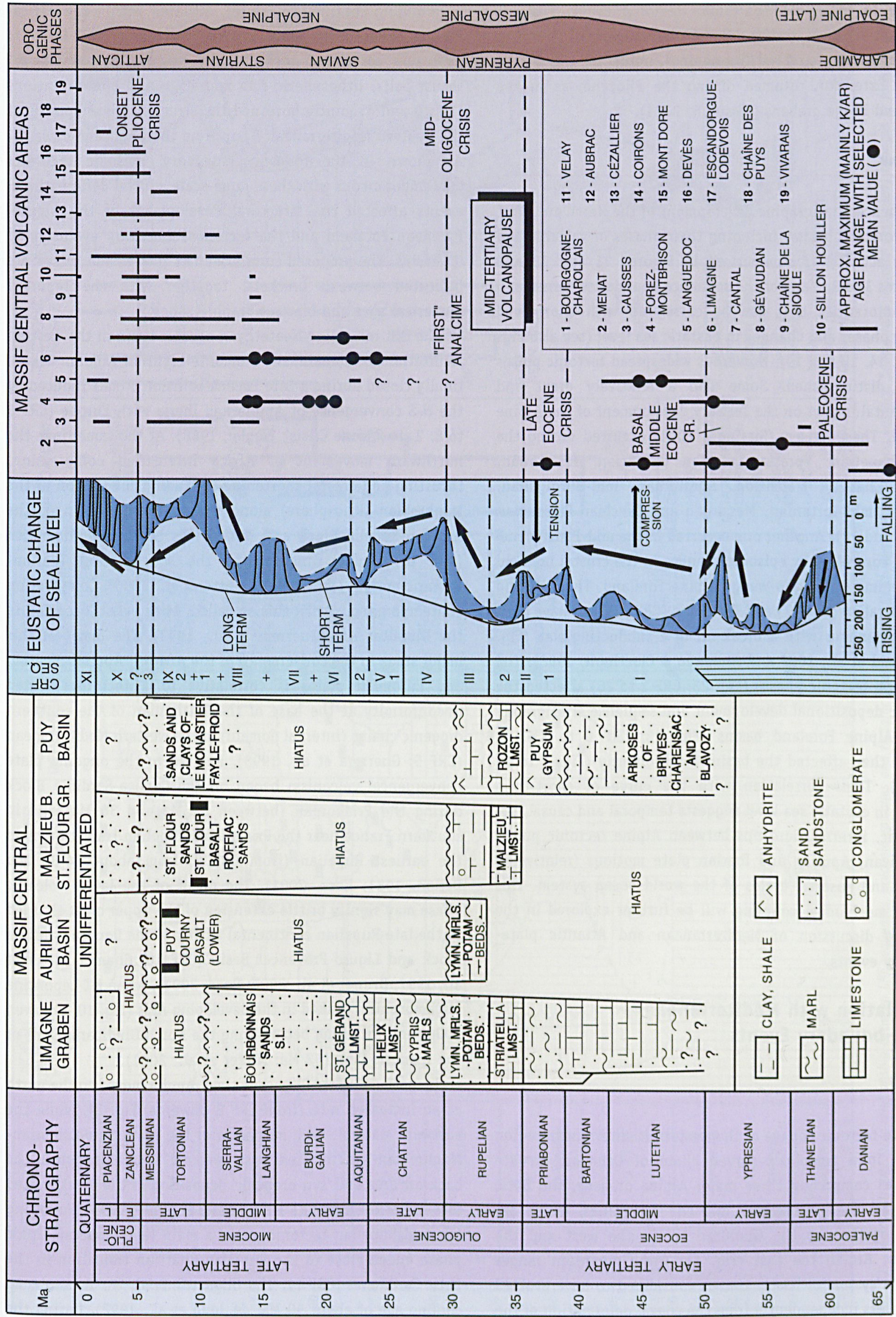


response to the same Aquitanian tectonic event. Post-rift deposition occurred during a Burdigalian-Messinian period of E-W compression and (still ongoing) uplift of the Massif Central. Extension resumed during the Pliocene, as in the Rhône and Rhine grabens (Sissingh, 2001).

\section{Overview}

The sequence stratigraphic development of the North and West Alpine Foreland basins, including their phases of volcanic and tectonic activity, is summarised in Figures 21 and 22 and Enclosures 3 to 8. Many of the sequence boundaries correspond to unconformities that can be correlated with short-lived tectonic phases and changes in eustatic sea level (see also Figs $8,9,10,14,18$ and 19). Numerous widespread tectonic pulses can be distinguished. Some had a relatively great and fundamental impact on the Tertiary development of the Alpine Foreland. These 'crises' (Sissingh, 2001) occurred during the early Thanetian, Ypresian-Lutetian transition, Priabonian, Rupelian-Chattian transition, Aquitanian, mid-Burdigalian, Langhian, mid-Tortonian, Messinian and Zanclean-Piacenzian (Figs 21 and 22). Another one occurred in the mid-Pleistocene. All were controlled by episodic changes in the crustal far-field stress regime of the pro-wedge Alpine Foreland. Those during the Burdigalian (CRF 17) and Tortonian (CRF 22) may have been contemporaneous with a break-off of a subducting slab (Fig. 23; Schmid et al., 2002 and Andeweg \& Cloetingh, 1998). The short-term tectonic phases (Fig. 23; CRF 1 to 28) affected the Cenozoic depositional development and sequence stratigraphy of the Alpine Foreland basins (Fig. 23; CRF 0 to XI). In essence, they affected the basins isochronously (Figs 5 to 20 and 23). Their correlation with the curve of short-term changes in eustatic sea level suggests temporal and causal, i.e. kinematic, interrelationships between Alpine tectonic pulses and African, Apulian and Iberian plate motions (relative to Europe) and eustatic cycles of the world ocean system. This inferred mechanical coupling will be further explored in the following discussion of Mediterranean and Atlantic plateboundary events.

\section{Correlation with Mediterranean Plate-boundary Events}

\section{General}

The plate-tectonic collage of the western Mediterranean region resulted in a complexly-curved chain of Cenozoic arcuate structures comprising three major Alpine orogens, the Betic Cordilleras, the Maghrebides and the Apennines, which are linked together by the Gibraltar Arc in the west and the Calabrian Arc in the east (Fig. 1). These mountain ranges enclose a system of basins that is considered to have evolved more or less independently from the coeval deformation of the surrounding continents (Fig. 2). Situated within the AfricaEurope convergence zone, crustal shortening and back-arc extension associated with internal-external propagation of thrust belts, lithospheric slab migration and block rotations (Figs 3 and 4) jointly governed the structural development of the western Mediterranean Basin from the Oligocene onwards. As shown in the following summary, episodic tectonics contemporaneous with these large-scale, crustal deformational events affected the structural development of the AlpinoPyrenean Foreland and the tectonosedimentary evolution of its basins. The proposed correlative CRF phases and 'crises' are indicated between brackets, together with the reported numerical ages and biostratigraphic zones.

The last remaining Neotethyan oceanic basin in the western Mediterranean domain, the Piemonte-Ligurian-Alboran 0cean, finally closed during a Late Eocene collision climax induced by the N-S convergence of Apulia and Iberia with Europe (CRF 5 to 8; 'Late Eocene Crisis'; Ziegler, 1988). At the same time, the northward movement of Africa intensified compression, thrusting and crustal shortening (including subduction of the Maghrebian lithosphere) along the southern margin of the Alboran-Kabylia Block and caused this block to collide with (and to subduct underneath) the southeastern IberianBalearic margin (Frizon de Lamotte et al., 2000). Compression contemporaneous with this so-called 'Atlas event' occurred in the Gibraltar Arc (Guerrera et al., 1993). The onset of this major stage in the convergence of the African, Apulian, Iberian and European plates is correlative to a tectonics-related unconformity at the base of the Priabonian of the southern orogenic chains (internal domain) of the western Mediterranean (CRF 5; Guerrera et al., 1993). Related to the ongoing plate convergence, volcanism began on the Corsica-Sardinia Block during the Priabonian (between $39 \mathrm{Ma}$ and $36 \mathrm{Ma}$ ) and in southern France near the Priabonian-Rupelian transition or in the earliest Rupelian (from CRF 8; from about 34-35 Ma: Bellon, 1981; Roca, 2001). The onset of the latter volcanic phase may signify brittle extension of the upper crust that led to the late Rupelian continental rifting of the Corsica-Sardinia Block and Liguro-Provençal Basin (CRF 10; Chamot-Rooke et al., 1997; Brunet et al., 2000; Roca, 2001), when HT Lepontine metamorphism peaked in the developing Alps (Fig. 10; Brouwer, 2000) and thrusting began along the North Giudicarie Fault of the Insubric Line (32 Ma: Müller et al., 2001).

In 'post-collision' Oligocene time, Apulia moved to the north at an increased rate (from CRF 8 onwards; Fig. 3), while the eastward slab roll-back migration of the Apenninic-CalabrianMaghrebian Arc initiated 'post-orogenic' sedimentation in the back-arc area and 'syn-orogenic' deposition in the overthrusted fore-arc zone (from CRF 10 onwards; Séranne, 1999). Following the mid-Rupelian tectonic pulse, a main tectonometamorphic phase ended close to the Rupelian-Chattian transition in the Betic Cordilleras (CRF 11; 'Mid-Oligocene Crisis'; Ar-Ar minimum cooling age of about 30 Ma: de Jong et al., 1992). During the 

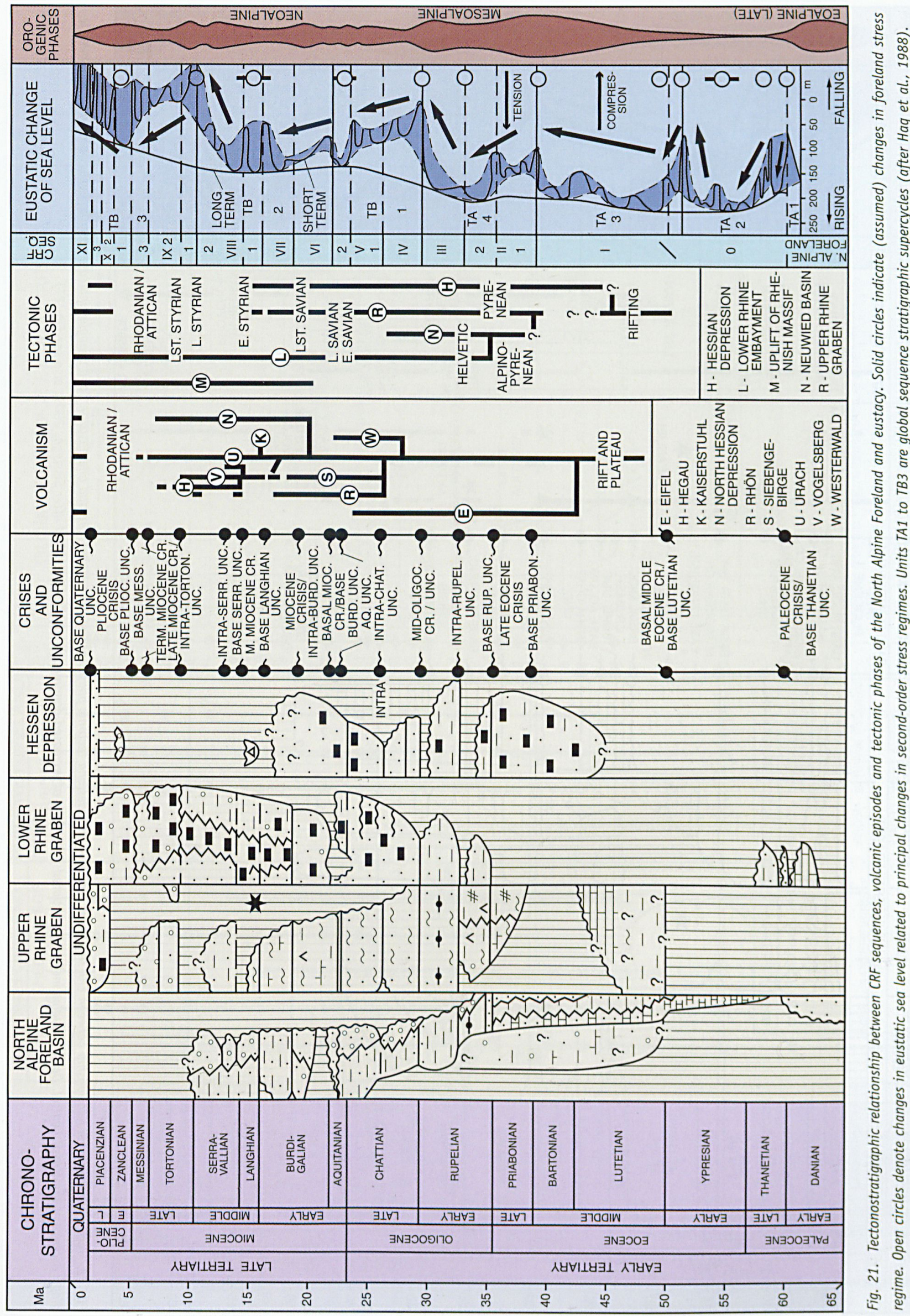


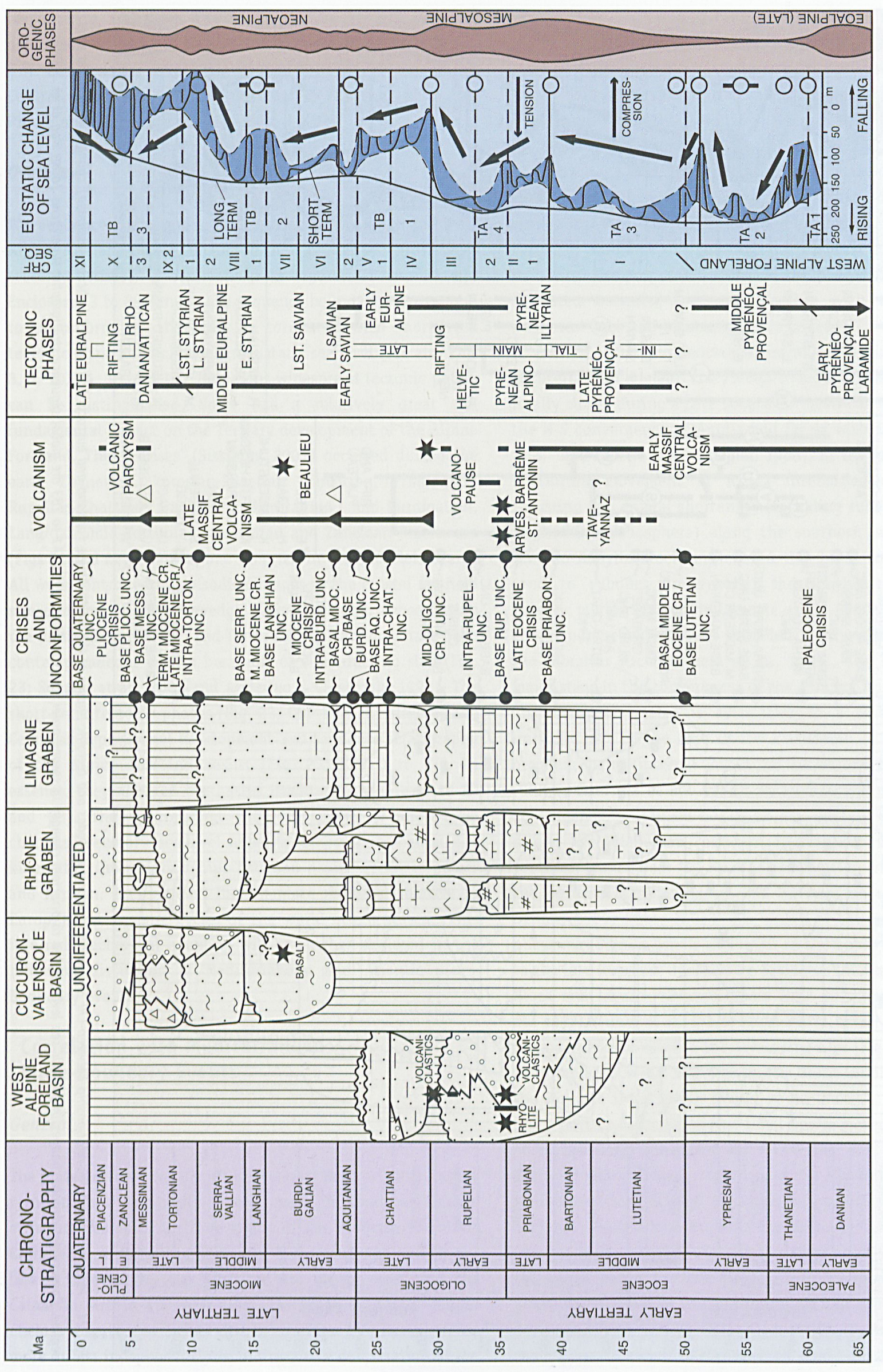




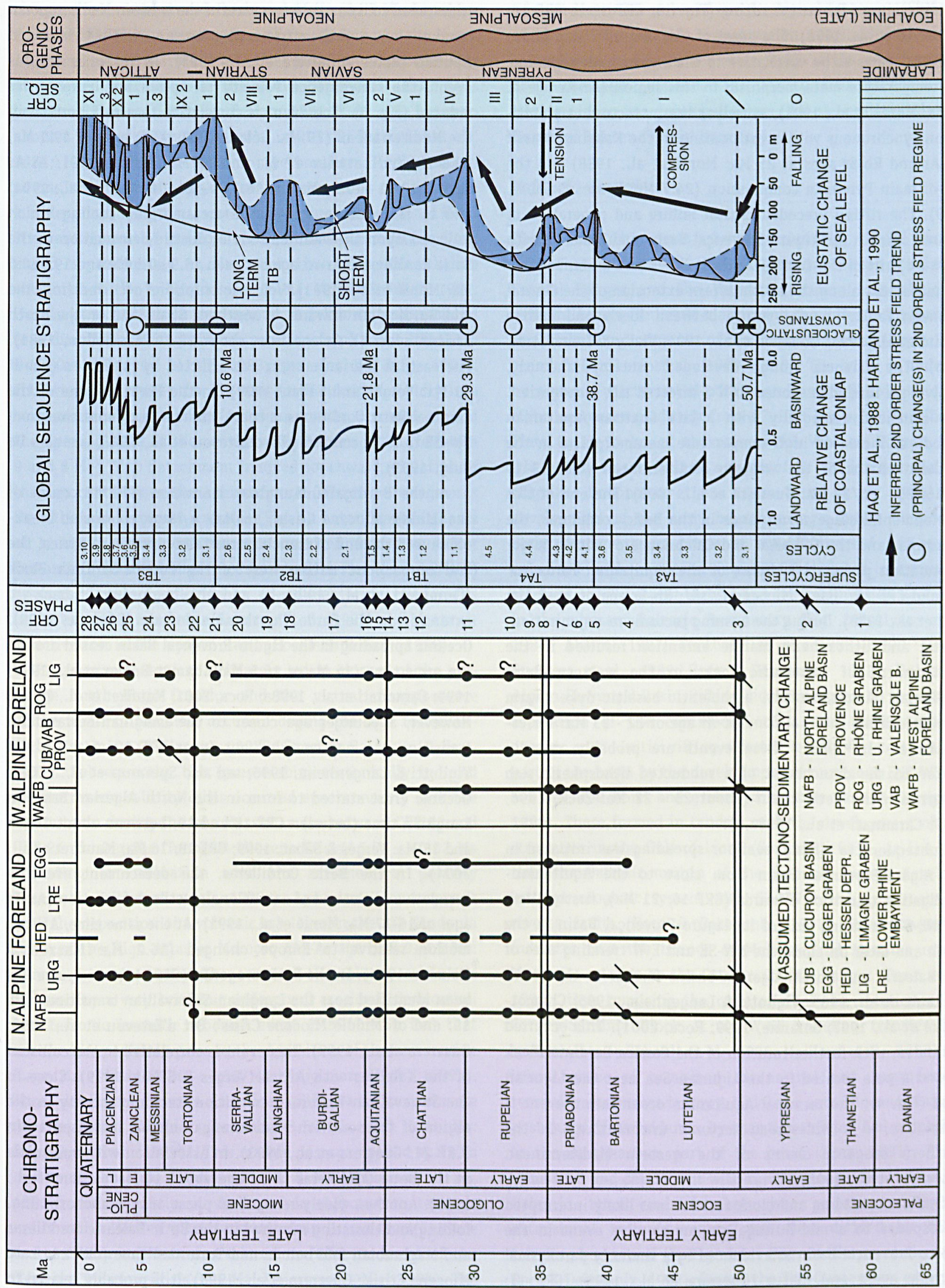


mid-Chattian-Aquitanian, the Gulf of Lions passive margin increasingly collapsed and opened in response to NNW-SSE trending Liguro-Provençal rifting (Fig. 19; CRF 12 to CRF 16; Hippolyte et al., 1993). The onset of this tectonic main phase (CRF 12) seems to be correlative to the end of high-pressure/ low-temperature meta-morphism in this region (Ar-Ar age of 25 Ma: Monié et al., 1991), as well as thermotectonic mylonitisation synchronous with overthrusting in the Kabylian massif (Ar-Ar and Rb-Sr ages at 25 Ma: Monié et al., 1988) and the end of main Pyrenean compression (24.7 Ma: Vergés \& Sàbat, 1999). The rifting preceded crustal failure and generation of oceanic crust in the Liguro-Provençal Basin simultaneous with eastward drift of the Corsica-Sardinia Block and dextral strikeslip movement along the southeastern extension of the Central Pyrenean Fault, i.e. the suture between Iberia and Europe (Gorini et al., 1993; Guennoc et al., 1994; Vially \& Trémolières, 1996). The Valencia Trough developed contemporaneously, involving a further response to N-S directed rift propagation. This coincided temporally with a late Chattian-Aquitanian episode of increased high-temperature metamorphism in the southern chains of the western Mediterranean (CRF 12 to 15/16; 25 - 21/22 Ma: Guerrera et al., 1993). The end of this developmental stage corresponds in the Betic Cordilleras, the Apennines and the Gibraltar and Calabrian arcs with a major deformation phase, the climax of the 'Aquitanian Paroxysm'

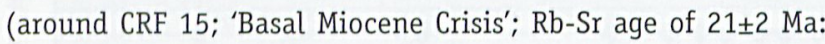
Zeck et al., 1989). During the ensuing tectonic re-organisation, crustal and lithospheric mantle extension resulted in the emplacement of ultramafic rocks in the western Betic Cordilleras. Simultaneously, a tholeiitic basaltic dyke swarm developed in its Internal Zone (K-Ar age of 22 - 23 Ma: TorresRoldán et al., 1986). These events are probably causally related to the detachment of a subducted lithospheric slab underneath the Betic chain (about 23 - 22 Ma: Zeck, 1996, 1999; Carminati et al., 1998a,b).

Subsequent to rifting, seafloor spreading was initiated in the Algéro-Provençal Basin from close to the AquitanianBurdigalian transition onwards (CRF 16; $21 \mathrm{Ma}$ ), firstly along the NE-SW trending axis of its Liguro-Provençal Basin in the north and later on along the NW-SE and E-W trending axes of the Balearic and North Algerian basins farther to the south (Rehault et al., 1985; Vigliotti \& Langenheim, 1995; ChamotRooke et al., 1997; Séranne, 1999; Roca, 2001). This occurred in tandem with further rotation of the Corsica-Sardinia Block around a pole located in the Ligurian Sea near the Ligurian Knot (Fig. 4). The terminal Aquitanian oceanisation event is correlative to a widespread tectonic unconformity in the southern orogenic chains of the western Mediterranean (Guerrera et al., 1993).

Seafloor spreading and block rotation was likely interrupted in response to a mid-Burdigalian compressive event in the Algéro-Provençal Basin as evidenced by a similarly paroxysmal tectonic event and hiatus (Guerrera et al., 1993) (CRF 17;
'Miocene Crisis'; 19 Ma: Burrus, 1984; Chamot-Rooke et al., 1997; Roca, 2001). This interruption corresponded with a widespread collision between parts of the western Mediterranean orogenic belt and the surrounding Iberian, North African and Apulian plates (Guerrera et al., 1993). In response to this event, the convergence velocity of Apulia and Europe was reduced (Fig. 3). The event is correlative to a tuff horizon in the Mediterranean (19 Ma: Gélard, 1979; K-Ar ages of $19.1 \mathrm{Ma}$, 18.8 $\mathrm{Ma}$ and between $22 \mathrm{Ma}$ and $18 \mathrm{Ma}$ : Bellon, 1981; $\mathrm{Ar}-\mathrm{Ar}$ ages of 18,31 - $\pm 0,14 \mathrm{Ma}$ and 18,37 - $\pm 0,14 \mathrm{Ma}$ : Odin et al., 1994) and to the closure age of the metamorphic cooling which followed upon the main episode of ductile deformation in the Betic Cordilleras (Ar-Ar age between 18.9 $\pm 0.5 \mathrm{Ma}$ and 19.5 \pm 0.5 Ma: Monié et al., 1991). Volcanic eruptions occurred from the mid-Burdigalian onwards in southern Spain and on the North African coast (K-Ar age from about 18-19 Ma: Bellon, 1981). The eastern Iberian margin was affected by extension (about 18 Ma: Vergés and Sàbat, 1999). In the Prebetic zone of the external Betic Cordilleras, a coeval change in compression from NW-SE to N-S occurred (Ott d'Estevou et al., 1988; see also De Ruig, 1992).

At the Burdigalian-Langhian transition (CRF 18; onset of the 'Middle Miocene Crisis'; $16 \mathrm{Ma}$ ), a Maghrebian slab breakoff caused the end of trench retreat along northern Africa, the end of back-arc rifting west of the Corsica-Sardinia Block (Carminati et al., 1998a,b) and the beginning of back-arc extension in the Sardo-Thyrrhenian domain (Séranne, 1999). 0ceanic spreading in the Liguro-Provençal Basin ceased around the same time (16 Ma or 16.5 Ma: Chamot-Rooke et al., 1997, 1999; Carminati et al., 1998a; Roca, 2001; Mauffret et al., 2004). However, a younger age closer to the Langhian-Serravallian transition can not be ruled out (near CRF 19; 14 - 15 Ma: Vigliotti \& Langenheim, 1995; see also Speranza et al., 2002). 0ceanic crust started to form in the North Algerian Basin in Langhian time (between CRF 18 and 19; between about $16 \mathrm{Ma}$ and 15 Ma: Vergés \& Sàbat, 1999; CRF 18; 16 Ma: Mauffret et al., 2004). In the Betic Cordilleras, the detachment event is correlative to the end of extensional ductile deformation (Ar-Ar ages of 16-17 Ma: Monié et al., 1991). At the same time, Africa's motion relative to Europe changed (16.2 Ma: Mazzoli \& Helman, 1994). In the Betic orogenic belt, a tectonic pulse has been identified near the Langhian-Serravallian transition (CRF 19; end of 'Middle Miocene Crisis'; Ott d'Estevou et al., 1988; Guerrera et al., 1993). This event is correlative to the collision of the Kabillies with Africa (Vergés \& Sàbat, 1999). Close to the Serravallian-Tortonian transition, tectonic activity in the region of the southern Mediterranean chains increased again (CRF 21; Guerrera et al., 1993), in association with volcanism in the Betic Cordilleras (K-Ar age about 10 Ma: Bellon et al., 1983). Another, widely-recognised phase of crustal shortening, folding and thrusting occurred in the Betic-Balearic cordilleras and Maghrebian fold belt in mid-Tortonian time (CRF 22; 'Late Miocene Crisis'; Guerrera et al., 1993). It is probably related to 
a change in direction of the convergence of Apulia and Europe (Fig. 3; 8.9 Ma: Mazzolli \& Helman, 1994), the onset of dextral oblique shortening between Iberia and Africa ( 8 - 9 Ma: Lonergan \& White, 1997), the termination of the opening of the North Algerian Basin (8 Ma: Mauffret et al., 2004) and the beginning of renewed volcanism in the Betic Cordilleras ( $\mathrm{K}-\mathrm{Ar}$ ages between $10 \mathrm{Ma}$ and $8.8 \mathrm{Ma}$ : Bellon, 1981; K-Ar ages between about $8 \mathrm{Ma}$ and 7 Ma: Bellon et al., 1983; Di Battistini et al., 1987; Hernán et al., 1987). In the southern Mediterranean chains, this tectonomagmatic event seems to be correlative to a widespread tectonic unconformity (Guerrera et al., 1993). The development of the North Algerian Basin and Tellian front ended approximately at the same time with calc-alkaline volcanism in the Tellian domain (8 Ma: Vergés \& Sàbat, 1999; Hernán et al., 1987). In the Prebetic, it is known to correspond to a directional change in compression from about NW-SE to N-S (Ott d'Estevou et al., 1988; see also De Ruig, 1992). Following this event, the Alboran Basin subsided rapidly in a back-arc tensional setting. All these events occurred around the opening time of the southern Tyrrhenian Basin (between 9 and $8 \mathrm{Ma}$ ). Slab detachment induced southward migration of the depocentre along the Apenninic and Calabrian arc segments from the mid-Tortonian onwards (Fig. 4). Later discrete phases of tectonic activity in the arcs occurred from the latest Tortonian ('Terminal Miocene Crisis' to 'Mid-Pleistocene Crisis') onwards. They are reflected by re-sedimentation phenomena in the adjoining foredeeps (Guerrera et al., 1993) and by thrust re-activation in the orogen itself (Bocaletti \& Sani, 1998).

Progressive tectonism ultimately led to closure of the prowedge North Betic Corridor and the virtual disappearance of the Strait of Gibraltar occurred during the late Tortonianearly Messinian (Weijermars, 1988; Sanz de Galdeano \& Vera, 1992). Subsequently, the (presumably) tectonically induced Mediterranean salinity crisis occurred synchronously over the entire basin during the late Messinian (in between CFR 23 and CRF 24; during the 'Terminal Miocene Crisis'; $5.96- \pm 0.02 \mathrm{Ma}$ according to calibration with the astronomical polarity timescale; Krijgsman et al., 1999a). Age-wise, it corresponds with the deposition of a volcanic ash layer in the Aït Kandoula Basin of the High Atlas in Morocco (Ar-Ar age of $5.9 \pm 0.5 \mathrm{Ma}$ : Benammi et al., 1995). The onset of the salinity crisis was followed by a very brief but widespread erosional desiccation and tectonic isostatic rebound event (5.59 - $5.50 \mathrm{Ma})$ that occurred immediately prior to the deposition of the non-marine 'Lago Mare' beds (5.50 - 5.33 Ma: Krijgsman et al., 1999a). These developments were associated with the tectonic closure of the Rifian Corridor (between 5.59 Ma and 5.33 Ma: Krijgsman et al., 1999a). This marine passage opened again in mid-Tortonian time (about CRF 22; 8 Ma: Krijgsman et al., $1999 b)$. Subsequently, it shallowed in response to tectonic uplift and a limited glacio-eustatic drop in sea level(?) close to the Tortonian-Messinian transition (CRF 23; onset of the 'Terminal Miocene Crisis'; 7.2 Ma: Krijgsman et al., 1999b). The isolation of the Mediterranean Basin from the Atlantic 0cean lasted until the Miocene-Pliocene transition, when, after a latest Messinian pulse of compressional tectonics (Chalouan et al., 1997), eustatic transgression re-established marine communication via the Gibraltar Strait at the very beginning of the Zanclean. This ended the salinity crisis and the modern Mediterranean Sea developed (from CRF 24 and the end of the 'Terminal Miocene Crisis' onwards).

\section{Valencia Trough}

The Valencia Through is a broadly triangular, NE-SW trending basin that extends over some $400 \mathrm{~km}$ in between the Catalan Coastal Ranges and the Valencia-Castellon area along the eastern Iberian Peninsula margin and the Balearic Promontory, the offshore prolongation of the Betic Cordilleras (Fig. 1; Encls 1 and 2; Fontboté et al., 1989, 1990). The basin is underlain by a strongly attenuated continental crust. The depth of the Moho decreases gradually from $27-30 \mathrm{~km}$ below the Iberian Plate to $15-16 \mathrm{~km}$ at the axis of the Valencia Trough, from where it increases again to a depth of $22-24 \mathrm{~km}$ near Mallorca (Fig. 24; Dañobeitia et al., 1992; Torné et al., 1996). The development of the basin began during a latest Oligocene Early Miocene main phase of NW-SE directed rifting that coincided with counteracting NW-SE directed compression, stacking of NW-vergent thrusts and syn-compression deposition in the adjacent Balearic Promontory (Fig. 24; Alvaro et al., 1984; Alvaro, 1987; Fontboté et al., 1989, 1990; RamosGuerrero et al., 1989; Roca \& Desegaulx, 1992). Unlike the Algéro-Provençal Basin, rifting did not progress to the stage of separation of the continental crust and emplacement of oceanic crust. Initial rifting affected mainly the northwestern part of the basin by the development of numerous ENE-WSW to N-S oriented horst and graben structures (Roca \& Desegaulx, 1992). These formed in tandem with the development of such structures in the Gulf of Lions (Séranne, 1999). At the same time the Balearic margin of the Valencia Trough developed into an orogenic system with SE-NW trending thrusts and reverse faults (Roca \& Desegaulx, 1992). Palaeomagnetism indicates that the islands of Mallorca and Menorca rotated clockwise relative to the Catalan Coastal Ranges (Parés et al., 1992), thus opposing the counter-clockwise rotation of the Corsica-Sardinia Block at a NW-SE trending transfer fault system (Fig. 4; Rehault et al., 1985; Maillard et al., 1992). The initial phase of combined extensional and compressional tectonics was succeeded by a Middle to Late Miocene period of post-main rift subsidence. By that time, rifting had propagated to the southeastern part of the basin (Roca, 2001). At the same time and concurrent with further clockwise rotation, the Balearic thrust-and-fold belt was re-activated by an extensional tectonic regime and thus divided by NE-SW trending horsts and (half)grabens (Fig. 24; Torres et al., 1993; Roca \& Desegaulx, 1992). During the Plio-Quaternary, extension 


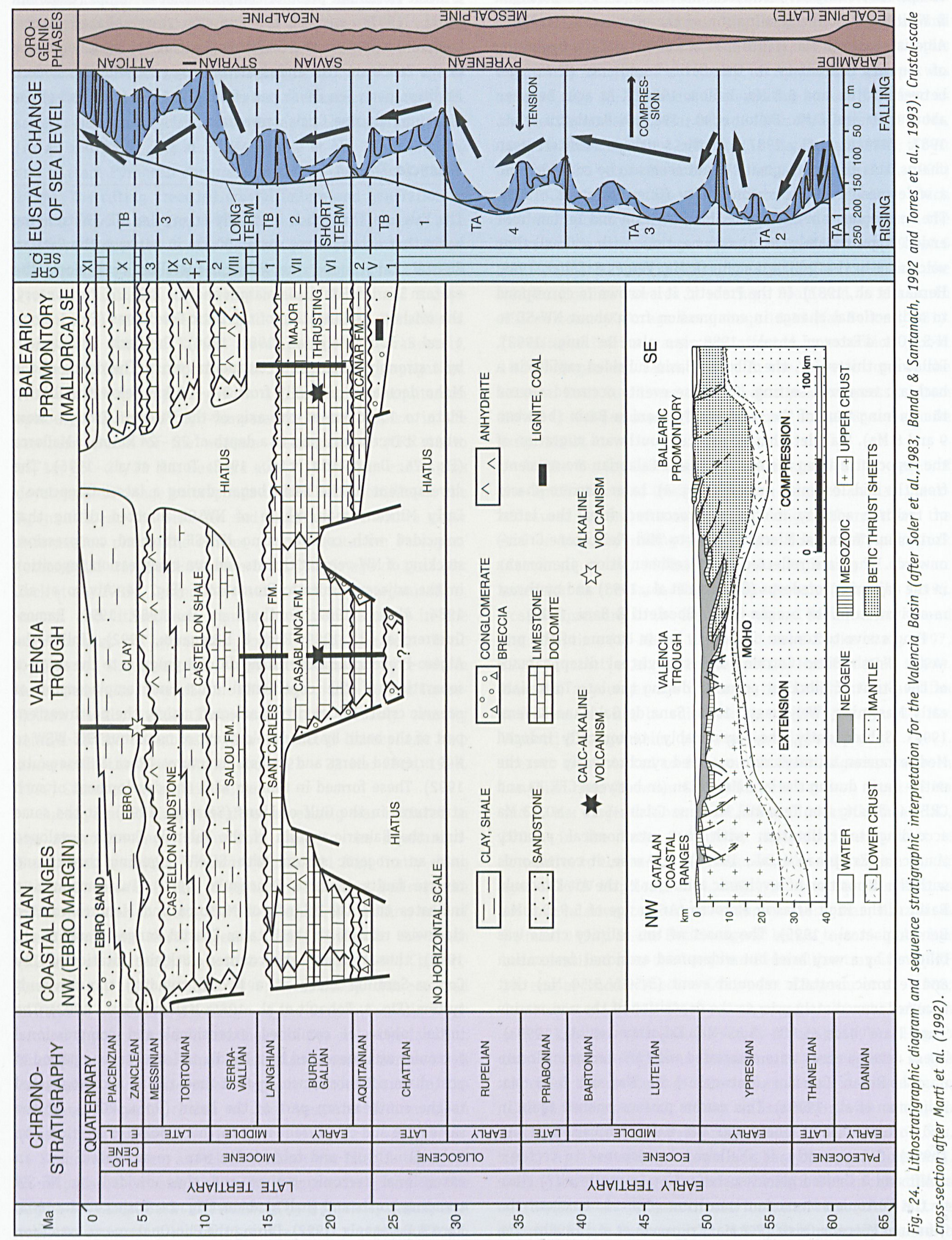


resumed simultaneously with uplift along the Iberian margin of the Valencia Trough (Maillard et al., 1992; Janssen et al., 1993).

Two well-differentiated cycles of volcanic activity separated by a non-volcanic period can be distinguished (Fig. 24; Martí et al., 1992; Roca, 2001). The first cycle (late Chattian-early Serravallian; K-Ar ages between $25 \mathrm{Ma}$ and $12-13 \mathrm{Ma}$; from CRF 12 to CRF 20 ?) corresponds to the initial and main phases of rifting in the northwestern part of the offshore basin. Causally, it was probably related to compression in the southeastern basin, as induced by the subduction of Apulia-Africa beneath Iberia-Europe. It is characterised by the extrusion of calc-alkaline andesitic and pyroclastic rocks. The second cycle (Tortonian-Recent; K-Ar ages from $10 \mathrm{Ma}$ to $0.3 \mathrm{Ma}$; from CRF 21 onwards) is typified by poorly differentiated alkaline basalts. Their extrusion was associated with back-arc extension in the southeastern basin. The change in type of volcanism (between about $12 \mathrm{Ma}$ and $10 \mathrm{Ma}$ ) may reflect the detachment of a rolled-back subduction slab that induced upwelling of hot asthenosphere (Roca, 2001).

The origin and subsequent evolution of the Valencia Trough has been studied extensively from geological and geophysical points of view and is much disputed (Banda and Santanach, 1992). Various explanatory models have been proposed for the geodynamic development of the basin, mainly because of interpretational problems arising from the co-occurrence of widespread NW-SE directed compression in between the African/Apulian and European/Iberian plates and similarlyoriented tension in the Valencia Trough (Figs 2 to 4 and 24). Following Ziegler (1994), the trough is considered to be a post-Oligocene, southward extension of the European Cenozoic Rift System. However, back-arc extension may have helped to shape the trough. Alternatively, the trough has been viewed as a compressional and flexural foreland-type basin of the Betic belt that occurs on top of an aborted rift (Fontboté et al., 1990; Roca \& Desegaulx, 1992; questioned by Torres et al., 1993).

The depositional record of the Valencia Trough (Fig. 24; Encls 4, 6 and 8) comprises basal continental clastics which are overlain by shallow-marine carbonates and shallow- to deepmarine clastics including (hemi)pelagic clays and calcareous turbidites (Soler et al., 1983; Dañobeitia et al., 1990; Clavell \& Berastegui, 1991; Banda \& Santanach, 1992; Bartrina et al., 1992; Roca \& Desegaulx, 1992; Torres \& Bois, 1993; Torres et al., 1993). The basal clastics are late Chattian in age. They accumulated in graben-like subbasins with fault-bounded margins. These were successively overstepped and submerged by marine syn-rift deposits during the Aquitanian-Langhian. Under influence of increasing tectonic activity, the latter strata accumulated in an initially slowly but ultimately rapidly subsiding basin (Torres et al., 1993). Following a break in sedimentation near the Langhian-Serravallian transition, the lower sedimentary sequence was succeeded by a post-main rift sequence consisting of calcareous and clastic deposits of Serravallian-Tortonian age. This sequence is overlain by a remnant Messinian series with evaporites, which is truncated by a regional, high-relief unconformity representing a widespread subaerial system of canyons and valleys developed in response to the terminal Miocene salinity crisis (Escutia \& Maldonado, 1992). Deposition of these beds occurred in an overall slowly subsiding basin (Torres et al., 1993). In conjunction with rapid basinal deepening related to post-rift thermal relaxation, an eastward prograding palaeo-Ebro deltaic complex developed along the Catalan Coastal Ranges from the Piacenzian onwards.

The tectonostratigraphic record of the Valencia Trough reveals the episodic extension- and compression-related depositional conditions. However, the age of the onset of rift development is not well constrained (Fig. 24; Encl. 8; CRF 12 ?). The initial rifting phase began in the late Chattian with the localised deposition of poorly dated continental strata (Bartrina et al., 1992) in an evolving horst-and-graben setting, and continued until the Aquitanian-Burdigalian transition. Rifting was contemporaneous with the initial thrusting of the Balearic Promontory (Ramos-Guerrero et al., 1989), by which a 'synorogenic' series of out-of-sequence pull-apart basins in a piggy-back setting formed on the island of Mallorca (Alvaro et al., 1984). Unconformable deposition of Aquitanian breccias and shallow-marine carbonates testify of transgressive depositional conditions associated with tectonic activity (CRF 14). The breccias at the base of the Aquitanian are possibly unconformably overlain by limestones (Soler et al., 1983). The postulated intra-Aquitanian break (Fig. 24; CRF 15) is virtually coeval with the termination of rifting in the Rhône Graben (Monleau et al., 1988) that just preceded the crustal separation of the Corsica-Sardinia Block and the European mainland. It also correlates with the rifting between the Balearic-Alboran and Kabylian blocks that was associated with clockwise rotation of Kabylia and slab detachment in the Betic domain (Fig. 25; Zeck, 1996, 1999). The Aquitanian-Burdigalian transition is marked by a break-up unconformity (Fig. 24; Encl. 8; CRF 16). This sequence boundary is correlative to the onset of the main rifting and deepening phase of the Valencia Trough (Roca \& Desegaulx, 1992) and the beginning of major thrusting in the Balearic promontory (Alvaro, 1987; Ramos-Guerrero et al., 1989). At the Ebro continental margin a mid-Burdigalian facies change corresponds to an increase in coastal onlap and thermal subsidence and a decrease in extension of the trough proper (Fig. 25; CRF 17; Dañobeitia et al., 1990; Vergès \& Sàbat, 1999; Roca, 2001). At the opposite basin margin, the 'crisis' is represented by calc-alkaline rhyodacitic volcanism on Mallorca (K-Ar ages of 18.6 Ma and 19 Ma: Mitjavila et al., 1990; Martí et al., 1992). This event probably affected or interrupted the main phase of rifting in the northwestern Valencia Trough. In this region, rifting ceased probably during the Langhian (between CRF 18 and CRF 19; around 15 Ma: Torres et al., 1993; Dañobeitia et al., 1990; Roca, 2001). Around this time, the emplacement of the Balearic thrust system ended with a major 


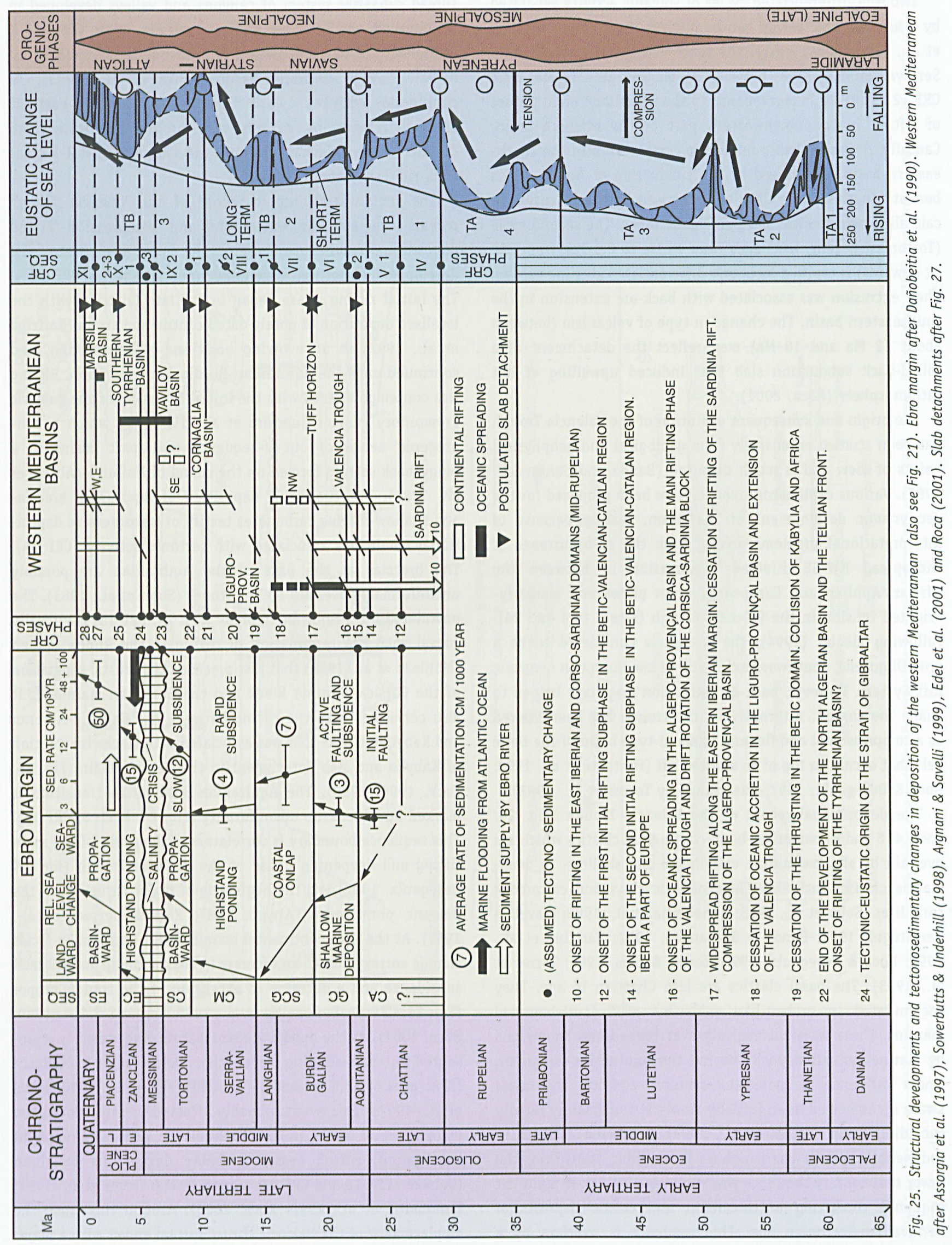


phase of additional thrusting and nappe piling (Fig. 24; Alvaro et al., 1984; Alvaro, 1987; Ramos-Guerrero et al., 1989; Gelabert et al., 1992; Torres \& Bois, 1993). These developments were geodynamically linked, with detachment of a Langhian slab as the causative factor (Figs 4 and 25). The Langhian-Serravallian transition is represented by a regional unconformity (Fig. 24; Encl. 8; CRF 19). This stratigraphic hiatus presumably developed in response to compression that preceded extension in the southern part of the Valencia Trough (Fig. 25; Encl. 8; (close to) CRF 20; Roca, 2001). In response to a collapse of its thrust edifice, the Balearic Promontory experienced a 'post-orogenic' phase of extension transforming the crust of the island of Mallorca into a host-and-graben system (Fig. 24). The collapse may be related to ongoing extension and oceanisation of the North Algerian Basin (Fontboté et al., 1990). A eustacy-related break in sedimentation occurred at the Serravallian-Tortonian transition (Fig. 24; Encl. 8). This change in depositional setting does not seem to be reflected by any tectonosedimentary event at the Ebro margin. However, it correlates with extension re-activation on Mallorca (Alvaro et al., 1984). Moreover, it occurred close to the onset of alkaline volcanism (Fig. 24; Encl. 8; CRF 21). Basinward propagation of the Castellon deltaic complex, was simultaneous with slow syn-rift subsidence of the basin, closure of the North Betic Corridor and narrowing of the Strait of Gibraltar (Weijermars, 1988), started during the Tortonian (Fig. 24; Dañobeitia et al., 1990). Rifting in the southern Valencia Trough ended at the Tortonian-Messinian transition (CRF 23; Roca, 2001). The Messinian salinity crisis ended in response to a tectono-eustatic event at the PlioceneMiocene transition (CRF 24). Pliocene coastal deposition along the Iberian margin was typified by an early phase of marine highstand ponding that was succeeded by a brief mid-Pliocene episode of erosion and a Late Pliocene period of rapid eastward progadation of the Ebro Delta (Fig. 24). At the same time, the initial, relatively stable deeper-marine setting became much shallower and hence more directly influenced by sea-level fluctuations and glacial climatic cycles. These conditions prevailed until the Quaternary (Fig. 25; Nelson \& Maldonado, 1990). In general, tectonic activity was limited after the Tortonian. Probably in response to Late Pliocene-Quaternary crustal doming, the eastern Iberian margin, the Balearic Promontory and the Valencia Trough area were uplifted (Banda \& Santanach, 1992; Janssen et al., 1993), while renewed extension (since the latest Oligocene-Early Miocene) and volcanism occurred in the Catalan Coastal Ranges (from about 3 Ma: Simón-Gómez, 1989) and on the Balearic Islands (CRF 25, CRF 27 and CRF 28; Pomar Gomà, 1979; Alvaro et al., 1984; Banda \& Santanach, 1992; Martí et al., 1992).

\section{Betic Basins}

Together with the Maghrebides and the Gibraltar Arc, the Betic Cordilleras form the westernmost Alpine chain of the
Mediterranean region (Fig. 1). The arcuate Betic-Rif mountain chain acquired its tectonic features during Late CretaceousCenozoic stages of the Alpine orogeny (Biermann, 1995). The evolution of the post-Oligocene stress regime in the Betic-Rif cordilleran region is recorded by a succession of discrete deformation phases (e.g. Galindo-Zaldívar et al., 1993). Rifting occurred contemporaneously with the late Chattian-early Aquitanian formation of the southernmost part of the European Cenozoic Rift System offshore eastern Spain (i.e., the Valencia Trough). Approximately NE-SW directed extension co-occurred with a similarly oriented regime of compression associated with the convergence of Apulia and Europe (Figs 2 to 4; Sanz de Galdeano, 1990, 2000). During this early phase of rifting, the first sediments accumulated in the Alboran Domain, the centrally located Internal Zone of the Betic-Rif orogen, which, at the time, was situated east of southern Spain (Sanz de Galdeano \& Vera, 1992). Southward progressing back-arc extension in the Western Mediterranean led to westward drift and relocation of the Alboran Domain from the midAquitanian onwards (e.g. Sanz de Galdeano, 2000). Around the Aquitanian-Burdigalian transition, the ongoing N-S directed compression between the African and Iberian plates co-existed with extensional, E-W directed opening of the Liguro-Provençal Basin (Fig. 25). By mid-Burdigalian time the westward ejected Internal Zone collided with the peripheral External Zone of southern Iberia (Sanz de Galdeano \& Vera, 1992). By the end of the Early Miocene, extension, simultaneous fragmentation and re-structuration of the Internal Zone was boosted by the oceanic opening of the North Algerian Basin (Mauffret et al., 2004). At the end of the Middle Miocene, widespread deformation occurred during the so-called Terminal Serravallian tectonic phase (Estévez et al., 1984). This episode of regional structural re-organisation culminated with the formation of numerous intramontane basins during the Late Miocene (Sanz de Galdeano \& Vera, 1992). Simultaneously, the westward drift of the Alboran Domain virtually ceased. From the latest Tortonian onwards, uplift of Betic mountain ranges rather than subsidence of the Betic intramontane basins governed the topographic evolution of the Betic Cordilleras.

Since the Miocene, sedimentary basins developed concurrently with the structuration and uplift of the surrounding cordilleras. The basin fills were typically derived from the nearby land masses of the Internal and External zones and sedimentation was mainly in marine settings (Fig. 26; Geel et al., 1992; Sanz de Galdeano \& Vera, 1992). The sedimentary sequences within the basins are typically bounded by tectonicsrelated unconformities. In the Internal Zone, ChattianAquitanian strata unconformably overlie the allochthonous Malaguide Complex, the source of these shallow-marine coarse clastics. The deposits accumulated either before or at the beginning of the principal deformation of the Malaguides (Sanz de Galdeano \& Vera, 1992) and contemporaneously with 
a strong, extension-related, adiabatic decompression of the Alpujarrides that was probably triggered by the detachment of a slab of subducted lithosphere beneath the Alboran Sea (CRF 14 to CRF 16; Ar-Ar ages of 25 Ma to 22 Ma: Monié et al., 1994). Unconformable clastic sedimentation continued until the midBurdigalian (Fig. 26; CRF 17), transgressively onlapping both the Malaguides and the Alpujarrides. Similarly, the External Zone was affected by late Chattian-Aquitanian tectonics. Close to the Valencia Trough, differential tectonic movements occurred in the eastern Prebetic (Geel et al., 1992; Geel, 1995, 2000) during mid-Chattian time (CRF 12; transition of zones P21 and P22), at the Chattian-Aquitanian transition (CRF 14) and during the 'Altomira' tectonic phase at the end of the Aquitanian (CRF 16; Andeweg, 2003). Another tectonosedimentary change occurred in the Prebetic during the Aquitanian (CRF 15; around the zonal N4-N5 transition; Geel, 1995; Tent-Manclús et al., 2001). In the same region, older tectonic phases occurred in mid-Rupelian time (CRF 10; at, or shortly after, the zonal P18-P19 transition) and at the Rupelian-Chattian transition (CRF 11; early during zone P21; Geel, 1995, 2000). Still older tectonic pulses have been dated at the Danian-Thanetian transition (CRF 1; De Ruig et al., 1991; see also Kenter et al., 1990), the Ypresian-Lutetian transition (CRF 3; Kenter et al., 1990; predated and succeeded by other tectonic events; Geel, 2000), as well as the earliest Bartonian rather than latest Lutetian (cf. Geel, 2000; CRF 4; late during zone P12), near the Bartonian-Priabonian transition (CRF 5; late during zone P14), the mid-Priabonian (CRF 6; at the zonal P15-P16 transition) and the late Priabonian (CRF 7; late during zone P16; Geel et al., 1998; Geel, 2000).

In the Prebetic, sediments accumulated seemingly uninterrupted on top of an unconformity dated to around the Chattian-Aquitanian transition (CRF 14). This correlates with the onset of the 'Aquitanian Paroxysm' and the extinction of the northern Iberian-European plate boundary (Roest \& Srivastava, 1991) by the mid-Burdigalian (CRF 17), when the first, truly major Miocene change in stress regime occurred (Fig. 26; 0tt d'Estevou et al., 1988; De Ruig, 1992). The latter tectonic phase, or 'Burdigalian Paroxysm', involved accelerated subsidence and uplift related to folding in the eastern Prebetic (Geel et al., 1992; Geel, 1995). This correlates with the onset of a structural re-organisation of the Subbetic in response to a collision of the Internal and External zones (Martín-Algarra et al., 1988) and backthrusting of the External Zone over the Internal Zone (Tent-Manclús et al., 2001). These events are associated with the development of the dextral Crevillente transcurrent fault system, the initiation of westward movement of part of the Subbetic along this fracture zone, the deposition of huge olistostromes in the Proto-Guadalquivir Basin (central and western sectors of the North Betic Corridor) and the accumulation of correlative allochthonous units in the late Burdigalian Guadix-Baza and Granada basins in the Internal Zone (Fig. 26; Sanz de Galdeano \& Vera, 1992). Simultaneously, the hot Alpujarrides cooled down rapidly (Ar-Ar age of $19-20$ Ma: Monié et al., 1994). However, this major event is not known from the Alboran Basin. After the mid-Aquitanian Castellana, or Iberica, tectonic phase (CRF 15; modified after Calvo et al., 1993 and Andeweg, 2003), the first syn-rift deposits accumulated without any distinct tectonosedimentary break until the onset of the main rifting phase. Rifting followed the development of an angular unconformity at the Burdigalian-Langhian transition (CRF 18; Comas et al., 1992, 1999; Jurado \& Comas, 1992). Following the development of a terminal, rather than an intra-, Langhian unconformity related to the Gudarrama 1, or Neocastellana, tectonic phase (Fig. 26; CRF 19; Calvo et al., 1993; Andeweg, 2003) and a coeval change in stress regime that induced wrenching movements in the External Zone (Martín-Algarra et al., 1988; 0tt d'Estevou et al., 1988; Geel et al., 1992; De Ruig, 1992; Sanz de Galeano \& Vera, 1992; Geel, 1995), thick breccias and other coarsegrained, regressive clastics accumulated in the Internal Zone from around the Langhian-Serravallian transition onwards (Fig. 26; CRF 19). From around that time, thrusting ceased in the External Zone and both rapid basin uplift and strong basin subsidence occurred (Geel, 1995). This tectonic instability continued to affect deposition in the Internal and External zones throughout the Serravallian. Especially in the ProtoGuadalquivir Basin, olistostromes continued to accumulate from the Gudarrama 2 tectonic phase onwards in conjunction with the ongoing tectonic re-organisation of the Subbetic (Fig. 26; from CRF 20 to CRF 23; Calvo et al., 1993; Andeweg, 2003). The best preserved basins postdate the Tortonian transition and occur in the Internal and External zones. They developed through tectonic re-activation of pre-existing faults induced by compression around the Serravallian-Tortonian transition (Fig. 26; CRF 21; zone N15: Martín-Algarra et al., 1988; 0tt d'Estevou et al., 1988; Sanz de Galdeano \& Vera, 1992). Large-scale tectonic uplift subsequently affected the basins of the Betics (Sanz de Galdeano \& Vera, 1992; Geel, 1995). Westward motion of the Internal Zone was terminated around the same time (Sanz de Galdeano \& Vera, 1992). A large number of sizeable intramontane basins originated around the Serravallian-Tortonian transition. An intra-Tortonian change in the tectonic stress regime of the Prebetic corresponds with the development of a stratigraphic hiatus and a change in lithofacies (Fig. 26; CRF 22; Ott d'Estevou et al., 1988; De Ruig, 1992). This main tectonic event affected the whole Betic chain, reflecting a relatively spectacular and widespread deformation of the Betic palaeorelief, that initiated the closure of the North Betic Corridor (in response to a north(west) movement of the Prebetic) and the transformation of the ProGuadalquivir Basin into the Guadalquivir Basin (Sanz de Galdeano \& Vera, 1992). In the Sorbas Basin of the internal Betic Cordilleras, the Messinian salinity crisis was preceded by a latest Tortonian tectonic phase represented by the development of an angular unconformity and the termination of 


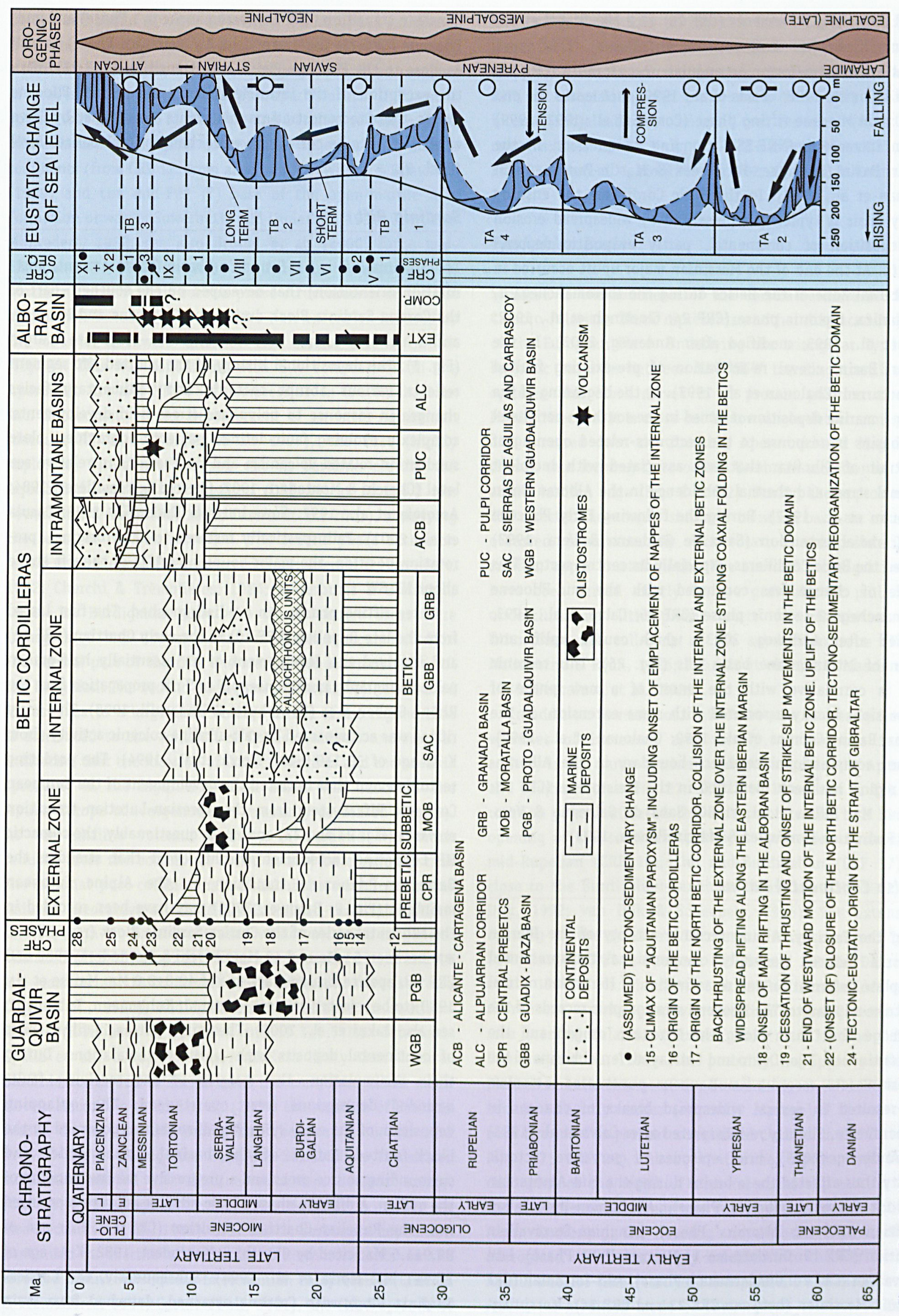

\section{产}

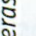


dextral strike-slip movements (CRF 23; >7.2 Ma: Stapel et al., 1996 modified after Krijgsman et al., 1999b). This event postdates the intra-Tortonian angular unconformity (CRF 22; Jurado \& Comas, 1992; Comas et al., 1999) that marks the end of the main Miocene rifting phase (Comas et al., 1992, 1999) and an increase in NNE-SSW trending compression in the Alboran Basin (Rodriguez-Fernàndez \& Martín-Penela, 1993; Chalouan et al., 1997). In the Betic Cordilleras the ensuing salinity crisis is typically represented by widespread erosion and deposition of continental, partly evaporitic deposits (Fig. 26). At the end of the Messinian major uplift occurred in the Internal Zone of the Betics during the Iberomanchega 1, or Rodanica, tectonic phase (CRF 24; Cloetingh et al., 1992; Calvo et al., 1993; modified after Andeweg, 2003). In the Alboran Basin, coeval re-activation of pre-existing faulted folds occurred (Chalouan et al., 1997). At the beginning of the Pliocene, marine deposition resumed in the southern peripheral Betic basins in response to the tectonics-related opening of the Strait of Gibraltar that was associated with incipient tensional stress and thermal subsidence in the Alboran Basin (Chalouan et al., 1997). During the following Early Pliocene period, radial extension (Sanz de Galdeano \& Vera, 1992) affected the Betic Cordilleras, especially its central sector. This episode of change was concluded with the mid-Pliocene Iberomanchega 2 tectonic phase (CRF 25; Calvo et al., 1993; modified after Andeweg, 2003), which caused uplift and erosion of intramontane basin fills (Fig. 26). This tectonic event is correlative with the onset of a new phase of compression, locally associated with some extension, in the Alboran Basin (Campos et al., 1992; Chalouan et al., 1997). Another compressional sequence boundary in the AlboranBetic region has been identified in the Pleistocene (CRF 28; about 1 Ma: Dillon et al., 1980; Sanz de Galdeano \& Vera, 1992; Rodriguez-Fernàndez \& Martín-Penela, 1993).

\section{Spanish Continental Basins}

During the Tertiary, Alpine tectonic activity of the Iberian Peninsula induced generally compressional/transpressional intra-plate deformation and re-activation of Hercynian normal and strike-slip faults. The Neogene stratigraphic records of the pro-wedge Ebro Basin along the Pyrenean orogen and the intracontinental Tajo, Duero and Catalayud-Teruel basins of the Spanish meseta, record a simultaneous, punctuated tectonism that resulted in several widespread breaks or changes in sedimentation. Slightly re-interpreted after Calvo et al. (1993) and Andeweg (2003), brief episodes of pervasive tectonic activity thus affected these basins during the mid-Aquitanian (CRF 15; Castellana/Iberica Phase), Aquitanian-Burdigalian transition (CRF 16; 'Altomira' Phase), Langhian-Serravallian transition (CRF 19: Guadarrama 1/ Neocastellana Phase), late Serravallian (CRF 20: Guadarrama 2 Phase), mid-Tortonian (CRF 22), mid-Messinian (between CRF 23 and CRF 24), Messinian-
Zanclean transition (CRF 24: Iberomanchega 1 Phase) and midPliocene (CRF 25: Iberomanchega 2 / Rodanica Phase) as well as close to the Pliocene-Pleistocene transition (CRF 27). With the exception of the intra-Messinian and terminal Pliocene pulses, these tectonostratigraphic events are assumed by Calvo et al. (1993) to be correlative with changes in global sea level (Encl. 8).

\section{Sardinia Rift}

The Sardinia Rift is a N-S trending basin (in its present, postrotation orientation) that developed on the southern part of the Corsica-Sardinia Block during the Oligocene and Miocene, and which represents the Gulf of Lions conjugate margin (Fig. 1). The depositional history of the aborted rift segment reflects various abrupt tectonic and sedimentary facies changes in response to polyphase stress-field developments, complexly evolving fault-defined palaeoto-pographies, plate subduction-related volcanism and fluctuations in relative sea level (Cherchi \& Montadert, 1982; Cherchi \& Trémolières, 1984; Assorgia et al., 1997; Sowerbutts \& Underhill, 1998; Casula et al., 2001). Palinspastically restored to their original, prerotation position, the major bounding faults of the rift strike about NE-SW.

Three rifting phases can be distinguished. The first lasted from the late Rupelian (CRF 10) to the early Chattian (CRF 12) and involved the development of an essentially half-graben palaeotopography in response to $\mathrm{N}$ to $\mathrm{S}$ rift propagation from the Rhône Graben area (Sowerbutts \& Underhill, 1998). This early rifting was accompanied by calc-alkaline volcanic activity (from $\mathrm{K}-\mathrm{Ar}$ age of $32.1 \pm 0.9 \mathrm{Ma}$ : Morra et al., 1994). The predating tectonic event that initiated the development of the European Cenozoic Rift System from the Ypresian-Lutetian transition onwards (Figs 21 and 22) and, more questionably, the climactic HP Lepontine tectonometamorphic event that straddles the Bartonian-Priabonian transition on the Alpine European mainland (Fig. 9; Brouwer, 2000) may have been recorded in the substratal series of the Corsica-Sardinia Block (resp. CRF 3 , age between $51 \mathrm{Ma}$ and $48 \mathrm{Ma}$ : Cherchi \& Montadert, 1982 and CRF 5 ?, apatite fission-track age of $40.8 \pm 2.0 \mathrm{Ma}$ : Mailhe et al., 1980 (to be rejected cf. pers. comm. J. Kuhlemann, Tübingen); see also Jakni et al., 2000). The initial rift-basin fill consists of continental deposits with marine intercalations. During their accumulation, the margins of the receiving faultbounded depressions were overstepped. The onlapping deposition of the early syn-rift sediments was governed by the block-faulted nature of the basinal palaeo relief and surrounding source areas and a progressive marine flooding of the graben. A discrete phase of calc-alkaline volcanism occurred near the Rupelian-Chattian transition (CRF 11; K-Ar age of 29.9 1.5 Ma: cited by Cherchi \& Montadert, 1982; K-Ar age of 28.5 \pm 1 Ma: Morra et al., 1994). Subsequently, the CorsicaSardinia Block with Calabria attached, detached from main 
Europe and began to move away from the European mainland, from the late Chattian onwards. In the process, faulting modified the Sardinia Rift into a largely underfilled complex of grabens, half-grabens and pull-apart basins. In these a voluminous series of ignimbritic and basaltic volcanics (incl. pillow lavas) and tuffites accumulated together with marine sediments (from CRF 12; from about $26 \mathrm{Ma}$ (Wilson \& Bianchini (1999) and the mid-P22 (?) base of the open-marine Ales Formation onwards; Sowerbutts and Underhill, 1998; Cherchi \& Montadert, 1982; see also Brunet et al. (2000) for a midChattian (27 Ma) deformation identified in the Alpi Apuane, northern Corsica). This second-phase structuration of the rift may be attributed to back-, or intra-, arc extension induced by the counter-clockwise drift of the Corsica-Sardinia Block (Fig. 4). This was concurrent with $\mathrm{E}-\mathrm{W}$ compression in the Apenninic Arc and NNE-SSW compression in the Maghrebian Arc. Subsequent to the development of an intra-Aquitanian hiatus (CRF 15; Assorgia et al. 1997), the first (highly explosive) ignimbrites poured out in Sardinia around the Aquitanian-Burdigalian transition (CRF 16; at 20.6 $\pm 0.2 \mathrm{Ma}$ : Sowerbutts \& Underhill, 1998; Casula et al., 2001), signifying the onset of oceanic accretion. The second-phase extension lasted until the mid-Burdigalian (CRF 17; Cherchi \& Montadert, 1982; Cherchi \& Trémolières, 1984; Sowerbutts \& Underhill, 1998). In Burdigalian time, the clastic source areas were transgressed and deeper-marine marlstones accumulated in the central part of the rift. The marlstones accumulated until the Langhian. The second main phase of extension terminated in response to a large-scale change in the stress regime that is attributed to the collision of Corsica-Sardinia and Apulia, indicating that the rotation of Corsica-Sardinia and the oceanic spreading in the Liguro-Provençal Basin were reduced. The Apulia-Europe convergence rate markedly decreased (Fig. 3). As calc-alkaline volcanic activity in Sardinia was much reduced after the collisional event, it may be concluded that the regional 'post-collision' rate of lithosphere subduction was reduced (Beccaluva et al., 1989). Extension- and subductionrelated, high-Mg basalts extruded while volcanism in general climaxed (CRF 17; resp. at $18 \mathrm{Ma}$ and between $21 \mathrm{Ma}$ and 18 Ma: Morra et al., 1997; Sowerbutts \& Underhill, 1998; see also Odin et al., 1994), and ignimbrites developed in southern Corsica (K-Ar ages of $18.9 \pm 0.4$ and $19.3 \pm 0.5 \mathrm{Ma}$ : 0ttavianiSpella et al., 1996). It is nevertheless likely that CorsicaSardinia continued to rotate until the Langhian, albeit much slower. According to Edel et al. (2001) the rotation of Sardinia ceased during the late Burdigalian (between 18.3 and 17.2 or $16.7 \mathrm{Ma}$ ). Around the Langhian-Serravallian transition, subduction-related calc-alkaline volcanism became extinct (CRF 19; at K-Ar age of $13.8 \pm 0.7$ Ma: Morra et al., 1994; see also Beccaluva et al., 1989). Siliciclastic-carbonate deposition continued in marine and continental environments of the arrested basin. Subsequent to Messinian compression (Cherchi \& Trémolières, 1984; Casula et al., 2001), the third episode of main rifting occurred during the Late Pliocene-Quaternary (from CRF 25 onwards). It resulted in the superposition of the Campidano Graben on the southern section of the Sardinia Rift, in association with pronounced (rift-flank) uplift and intense (sub)alkaline volcanism all over the island (from CRF 24 onwards; from 5.0-5.3 Ma to 0.1 - 0.2 Ma: Beccaluva et al., 1989; Fig. 25; Cherchi \& Montadert, 1982; Cherchi \& Trémolières, 1984).

\section{Tyrrhenian Basin}

Situated to the southeast of the Corsica-Sardinia Block, the Calabro-Peloritan Block represents another displaced fragment of the European Plate. Underlying the triangular Tyrrhenian back-arc basin in between ENE-WSW trending transfer fault systems, this block moved to its present position after the Middle Miocene. It is cross-cut by low-angle detachment planes and thrusted onto the flanking Apenninic and Maghrebian chains, thus forming the oroclinal Calabrian accretionary wedge at the leading edge (Figs 1 and 2). During the approximately ESE directed movement, similarly-trending back-arc extension occurred, simultaneously with rotation and translation of smaller, upper crustal blocks. The outward arc migration may have been driven mostly by the gravitational pull of the underthrusting lithospheric plate in association with lithosphere-slab roll-back at the subduction zone (Fig. 4; Malinverno \& Ryan, 1986; Rehault et al., 1987; Mascle et al., 1988; Beccaluva et al., 1989).

In addition to numerous late Paleogene and early Neogene episodes of increased and areally synchronous tectonic activity in the Sardo-Tyrrhenian domain and in the Apenninic and Calabrian arcs (Fig. 27; CRF 10 to 12 and 14 to 21), brief rotation phases affected the area prior to the late Neogene opening of the southern, principal Tyrrhenian Basin in the mid-Rupelian (CRF 10), the mid-Burdigalian (CRF 17) and close to the Burdigalian-Langhian transition (CRF 18 ?) (van Dijk, 1992; van Dijk \& Scheepers, 1995). The extensional opening of the southern Tyrrhenian Basin occurred in the Tortonian (CRF 22 ?; between 8.6 Ma and 7.8 Ma: Duermeijer et al., 1998; 8 Ma: Mauffret et al., 2004). It coincided with a short-term, counter-clockwise rotation in the Crotone Basin area (central Calabria; between about $8.6 \mathrm{Ma}$ and $7.6 \mathrm{Ma}$ : Duermeijer et al., 1998). Most probably, the opening reflects a plate-kinematic change of the domain's stress field. Possibly it occurred slightly earlier (around $9 \mathrm{Ma}$ ago) if it was coeval with the most important stress-field change of the Tortonian (Fig. 27; CRF 22). About that time, Apulia and Europe decoupled as the result of sinistral strike-slip motion along the transpressional Giudicarie fault system in the Southern Alps. Excluding the leading northwestern part of the microplate, which was deeply indented into the Western Alps, Apulia became thus relatively independent and discrete. As a result, its modified mode of convergence relative to Europe 


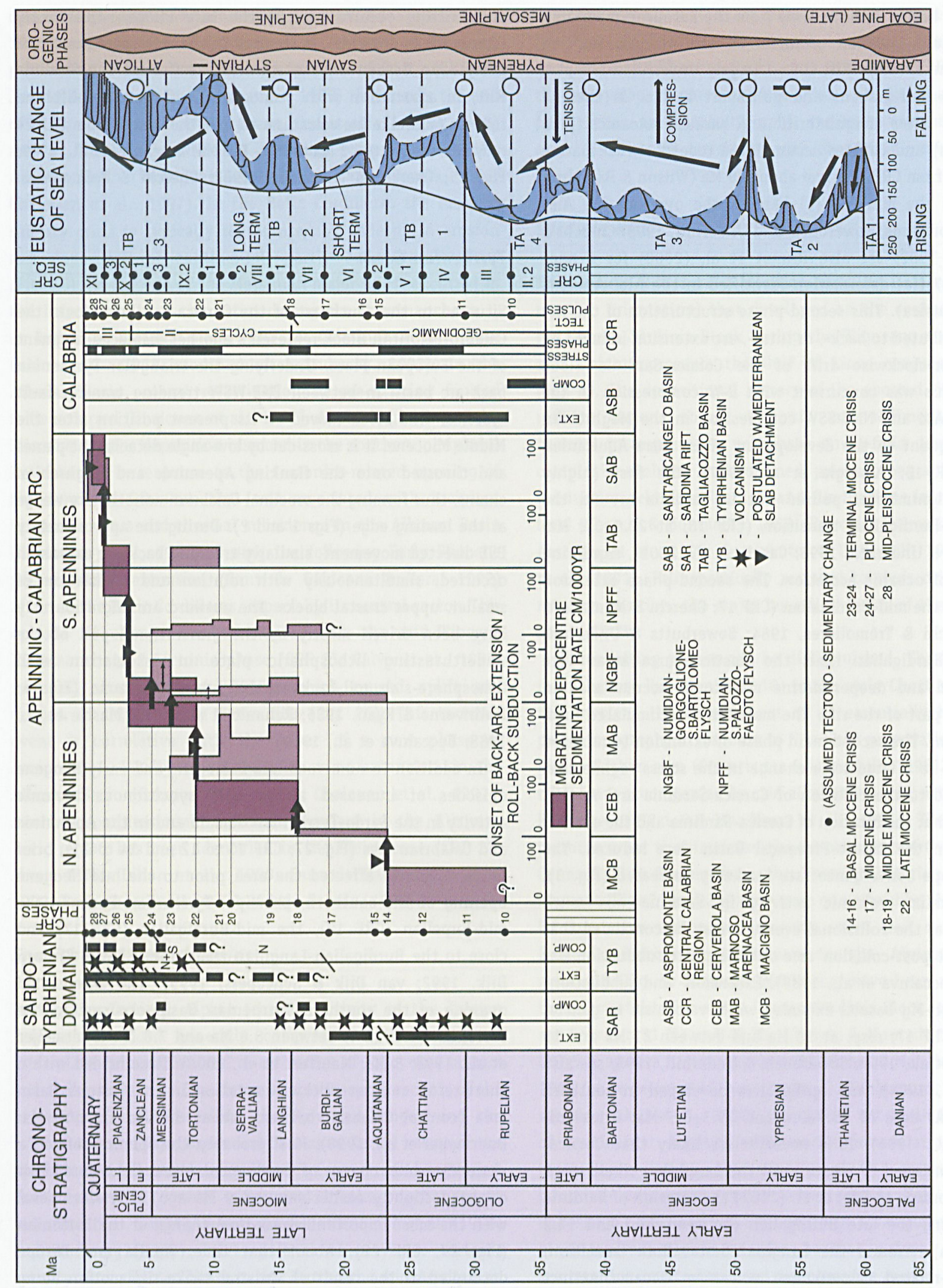

Fig. 27. Structural developments and tectonosedimentary changes in deposition in the Sardo-Tyrrhenian domain and Apenninic-Calabrian Arc in relation to the eastward roll-back and slab detachments of the westward-subducting Apenninic-Maghrebian lithosphere (also see Figs 4 and 21). Sardo-Tyrrhenian domain after Cherchi \& Montadert (1982), Beccaluva et al. (1989), Cipollari \& Cosentino (1995), Boccaletti \& Sani (1998), Sowerbutts \& Underhill (1998) and Argnani \& Savelli (1999). Apenninic-Calabrian Arc after van Dijk (1992), Weltje (1992), Hippolyte et al., (1994), van Dijk \& Scheepers (1995) and van der Meulen (1999). Late Rupelian onset of back-arc extension/rollback subduction after Séranne (1999) and Brunet et al. (2000). 
placed the Tyrrhenian Basin in a different plate-kinematic context (Mantovani et al., 1993). Consistent with the counterclockwise rotation of Apulia (Fig. 3), the overall NW-SE trending convergence of the African and European plates and the eastward retreat of the Apenninic-Calabrian subduction zone (Fig. 4), E-W trending extension propagated eastwards across the Tyrrhenian domain. At the same time, migrating compression affected the northeastern peri-Tyrrhenian margin from the intra-Tortonian until the Pleistocene. In response to the simultaneous occurrence of extension and compression in adjacent sectors, the northern Tyrrhenian Basin and the contiguous, inner (Tuscan) part of the Apenninic mountain belt were progressively transformed into a NNW-SSE trending horst-and-graben system. E-W trending rifting, as well as asthenosphere uplift, thinning of the previously (over-) thickened lithosphere (by the collision of Corsica-Sardinia and Apulia) and detachment of Calabria from the Corsica-Sardinia Block presumably began during the Langhian near Corsica with the opening of the Corsica Basin. Due to crustal shortening and thickening by E- and NE-verging units of the Apulian continental margin (Bartole, 1995; Carmignani et al., 1995), rifting propagated eastwards simultaneous with the emergence of the early Apenninic thrust-and-fold belt. Within the northern Tyrrhenian Basin, syn-rift developments ended in the mid-Pliocene (between $4 \mathrm{Ma}$ and $3 \mathrm{Ma}$ ), whereas nearer to the Apennines syn-rift deposition ceased from later Pliocene times onwards (Bartole, 1995). During this first-order structural development of the northern Tyrrhenian-Apenninic region, brief but widespread compressive pulses correlative to cover thrust re-activations in the northern Apennines interrupted post-Tortonian syn- and post-rift deposition. This happened most notably during the mid-Messinian, midZanclean, latest Piacenzian (CRF 26) and mid-Pleistocene (CRF 28) (Fig. 27; Boccaletti \& Sani, 1998). Other compressionrelated events have been identified in the central Apenninic foredeep for the mid-Burdigalian (CRF 17), late Serravallian (CRF 20), Tortonian (CRF 22; near the NN10-NN11 transition) and at the Tortonian-Messinian ? (CRF 23 ?; mid-NN11), Messinian-Zanclean (CRF 24) and Zanclean-Piacenzian (CRF 25) transitions (Cipollari \& Cosentino, 1995). The compressive phases interrupted magmatic activity and thus testify of crustalscale geodynamic developments. Late Cenozoic tectonomagmatic cycles occurred in and around the Tyrrhenian Basin from 8/8.5 Ma (CRF 22 ?) to $4.5 / 5 \mathrm{Ma}$ (CRF 24), 4.5/5 Ma to 2 $\mathrm{Ma}, 2 \mathrm{Ma}$ to $1.6 / 1.7 \mathrm{Ma}$ (CRF 27) and 1.2 Ma (CRF 28 ?) to Recent (Argnani \& Savelli, 1999). The first and third cycle respectively include the Vavilov and Marsili seafloor spreading events, whereas the other two relate to intra-plate volcanism.

Correlative post-Tortonian rotation phases occurred in the Sicilian Maghrebian-Calabrian Arc during the Messinian (about 6 Ma ago: van Dijk \& Scheepers, 1995), earliest Piacenzian (3.2 Ma ago, close to the transition of the Trubi and Narbone formations and contemporaneous with an acceleration in the opening of the southern Tyrrhenian Basin between $3.5 \mathrm{Ma}$ (CRF 25) and 2 Ma: van Dijk \& Scheepers, 1995; Duermeijer \& Langereis, 1998) and in the Pleistocene (CRF 28; $0.7-0.9 \mathrm{Ma}$ ago: van Dijk \& Scheepers, 1995). All three rotational events probably responded to a 'mediterranean-wide' change of the stress regime (Figs 25 to 27). The intra-Messinian event may be related to a collision of Apulia and the Balkan region in the Outer Hellenides that modified the drift of Apulia by a deflection into a more pronounced northerly direction (Mantovani et al., 1993). The mid-Pliocene deformation event around 3.5 Ma may be related to the end of oceanic spreading in the Vavilov Basin (Fig. 25; Argnani and Savelli, 1999). It was a prelude to a slowdown and almost complete cessation of the outward migration of the Tyrrhenian-Southern Apenninic rift-basin thrust-belt foredeep system (Mantovani et al., 1993) and correlates regionally with a change in deposition (Duermeijer \& Langereis, 1998). At the end of the Piacenzian or during the latest Pliocene-earliest Pleistocene (around CRF 27), the southern Tyrrhenian Basin collapsed concurrently with the cessation of oceanic spreading in the Marsili Basin (Fig. 25; Argnani \& Savelli, 1999), whereas the geodynamic setting of the area was strongly modified from the midPleistocene (CRF 28) onwards. The latter deformation phase is particularly represented by an accelerating uplift of the Southern Apenninic and Calabrian arcs from the end of their thrust-and-fold belt accretion onwards (Hippolyte et al., 1994; van Dijk \& Scheepers, 1995). These geodynamic changes of the late Cenozoic have been interpreted to be related to a series of laterally propagating detachments of the deeper subducted lithosphere slab (Figs 4 and 27). The phased process of slab failure in the subducting lithosphere has most likely been affected by episodic changes in the convergence velocity and direction of Africa and Apulia relative to Europe and by related changes of the intra-plate stress regime. The process is assumed to be reflected by a consecutive series of southeastward-directed, discrete jumps of foredeep depocentres (following periods of stasis) and by an equally episodic, rapid rebounding of non-detached, relatively shallow lithosphere (Figs 4 and 27; van Dijk \& Scheepers, 1995; van der Meulen, 1999).

\section{Correlation with Atlantic Plate-boundary Events}

Five major phases are distinguished for the Late Paleocene and later plate-kinematic development of the North Atlantic and Alpine-Mediterranean domains (see Structural Setting). In addition to major glacial events (Fig. 23) and changes in abyssal bottom-water circulation in the North Atlantic, which might be related to tectonic activity, the following events suggest a kinematic relationship between the re-organisations of the Mid-Atlantic seafloor axis (governed by ridge-push forces) and the plate-boundary events (governed by collision forces) as recorded in the Alpine-Mediterranean basins (Fig. 28): 


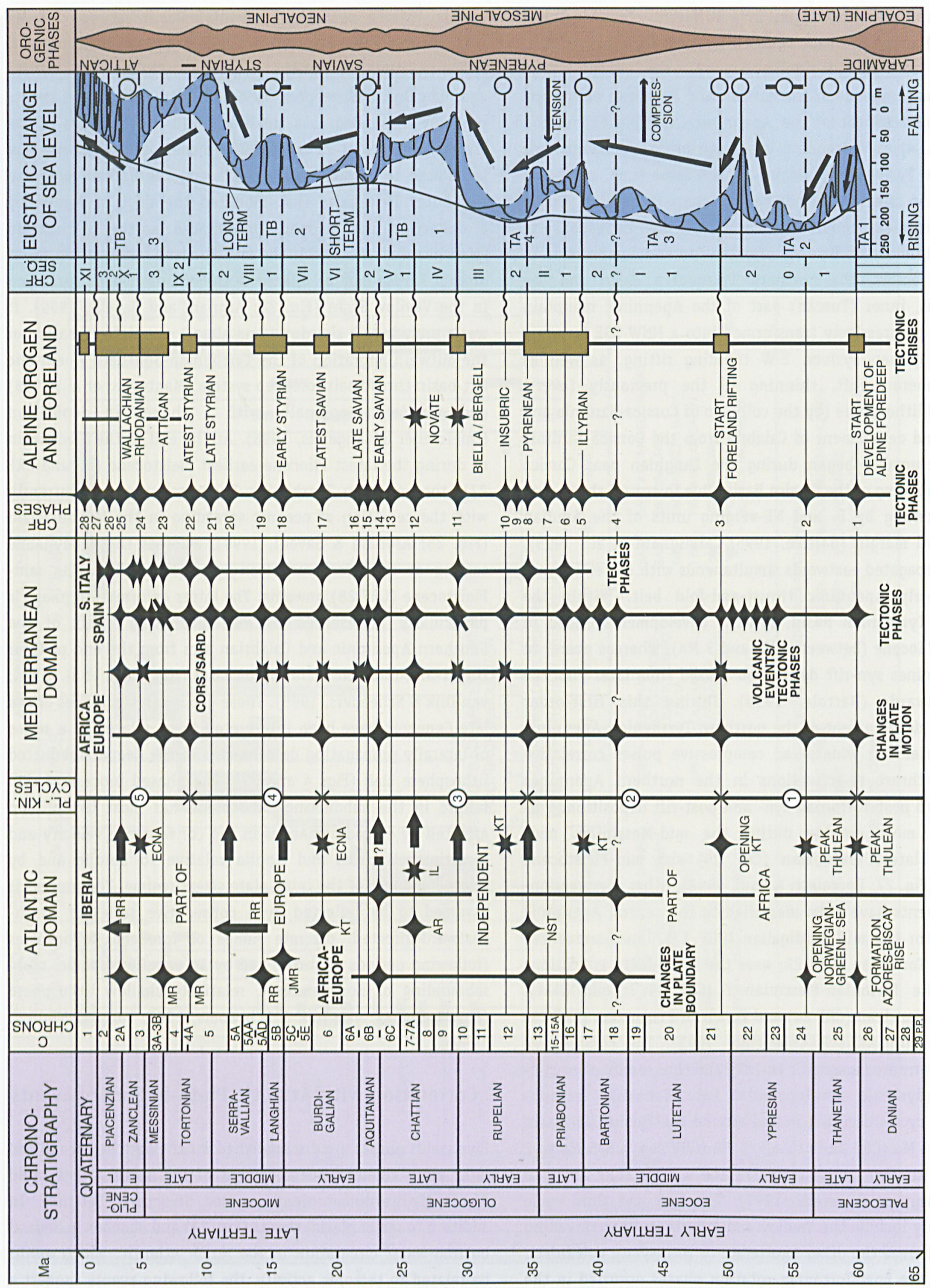

Fig. 28. Proposed kinematic relationship between Mediterranean and Atlantic plate-boundary events, Alpine orogenic phases and CRF sequences and phases of the North and West Alpine Foreland basins. Horizontal and vertical arrows indicate respectively abyssal circulation changes and uplifts. Stars signify volcanic events. $A R=$ Aegir Ridge; ECNA = Eastern Central North Atlantic; IL = Iceland; JMR = Jan Mayen Ridge; $K T=K i n g$ 's Trough; MR = Mohn's Ridge; NST = North Spanish Trough; $R R=$ Reykjanes Ridge. See text for details. 
- Anomaly 26: 60-59 Ma (CRF 1) - Formation of the Porcupine Microplate (Gulf of Biscay) and the Azores-Biscay Rise (Srivastava \& Tapscott, 1986). First peak of Thulean volcanism in the Greenland-Scotland region (Srivastava \& Tapscott, 1986; Morton \& Parson, 1988).

- Anomaly 24: 56 - $55 \mathrm{Ma}$ (CRF 2) - Onset of seafloor spreading in the Norwegian-Greenland Sea, resulting in the formation of a triple junction south of Greenland and the opening of the NE Atlantic (Klitgord \& Schouten, 1986). Second peak of Thulean volcanism in the Greenland-Scotland region (Morton \& Parson, 1988). First development of the King's Trough tectonic complex (Kidd \& Ramsay, 1986).

- Anomaly 21: 50 - 49 Ma (CRF 3) - Major change in central Atlantic spreading direction and onset of King's Trough rifting (Klitgord \& Schouten, 1986; Srivastava \& Tapscott, 1986), probably in relation to a counter-clockwise rotation of Africa-Iberia relative to Europe (Fig. 3) and in association with extrusion of basaltic rocks ( $52 \mathrm{Ma}$ : Kidd et al., 1982). Formation of a large part of the Iceland-Faroe Ridge (Srivastava \& Tapscott, 1986). Onset of the Late Pyrénéo-Provençal orogenic phase (Sissingh, 2001).

- Anomaly 18: 42 - $41 \mathrm{Ma}$ (CRF 4) - Re-activation of the Azores-Gibraltar Fracture Zone, resulting in Iberia's independence from both Africa and Europe (Roest \& Srivastava, 1991).

- Anomaly 17: 39 - 38 Ma (CRF 5) - European-Iberian plate boundary jumped from Boundary B to the King's TroughAzores-Biscay Rise-North Spanish Trough Fracture Zone (Roest \& Srivastava, 1991). Volcanism in the King's Trough region (37.5 - 38 Ma: Kidd et al., 1982). Rotation of the intra-plate, compressive stress trajectories of Europe and Iberia from NW-SE to NNE-SSW (Le Pichon et al., 1988; Lepvrier \& Martínez-Garcia, 1990). End of the Late PyrénéoProvençal orogenic phase and onset of the Alpino-Pyrenean orogenic phase (Sissingh, 2001).

- Anomaly 13: 35 - 34 Ma (CRF 8) - Porcupine Microplate becomes part of Europe (Srivastava \& Tapscott, 1986). Compression and subduction along the North Spanish Trough (Srivastava \& Tapscott, 1986). Abyssal circulation change in the North Atlantic and opening of the NorwegianGreenland-Arctic Sea (between $37 \mathrm{Ma}$ and $33 \mathrm{Ma}$ : Tucholke \& Mountain, 1986; Berggren \& Olsson, 1986; 35-36 Ma: Miller \& Fairbanks, 1985). End of the Alpino-Pyrenean orogenic phase and onset of the early Alpine orogenic phase (Sissingh, 2001).

- Anomaly 12: 33 - 32 Ma (CRF 10) - Near sea-level volcanism with extrusion of trachytic rocks in the King's Trough region (32.2 Ma: Kidd et al., 1982; Kidd \& Ramsay, 1986).

- Anomaly 10: 30 - 29 Ma (CRF 11) - Abyssal circulation change (28 - 31 Ma: Miller \& Fairbanks, 1985)

- Anomaly 7: 26 - 25 Ma (CRF 12) - Extinction of the Aegir Ridge (Uenzelmann et al., 1992). Increased volcanism at Iceland and abyssal circulation change (Berggren \& Olsson,
1986; 24 - 25 Ma: Miller \& Fairbanks, 1985). End of motion along the King's Trough (?), separation of the Jan Mayen Ridge from Greenland and onset of spreading across the Kolbeinsey Ridge (Srivastava \& Tapscott, 1986).

- Anomaly 6C: 24 - 23 Ma (CRF 14) - Iberia becomes part of Europe by the extinction of the King's Trough-AzoresBiscay Rise-North Spanish Trough Fracture Zone as the Europe-Iberia plate boundary and the establishment of the Africa-Europe plate boundary at the Azores-Gibraltar Fracture Zone (Roest \& Srivastava, 1991). Abyssal circulation change? (Miller \& Fairbanks, 1985).

- Anomaly 6: 20 - 19 Ma (CRF 17) - Onset of King's Trough rifting (Kidd \& Ramsay, 1986). Increase of volcanism in the East Central North Atlantic domain (from about 18 Ma: Schmincke, 1982).

- Anomaly 5C: 17 - 16 Ma (CRF 18) - Jan Mayen rift jump (Klitgord \& Schouten, 1986). Abyssal circulation change (about 17 Ma: Tucholke \& Mountain, 1986)

- Anomaly 5AA/AC: 14 - 13 Ma (CRF 19) - Onset of uplift and rifting of the Reykjanes Ridge (between about 14 - $13 \mathrm{Ma}$ and 10.5 Ma: Tucholke \& Mountain, 1986).

- Anomaly 5: 12 - 11 Ma (CRF 20) - Abyssal circulation change (about 12 - 11 Ma: Berggren \& Olsson, 1986; Tucholke \& Mountain, 1986).

- Anomaly 4A: 9 - $8 \mathrm{Ma}$ (CRF 22) - Plate re-organisation of spreading in (at least) the Mohn's Ridge region (about 9 Ma: Géli, 1991).

- Anomaly 3A: 7 - 6 Ma (CRF 23) - Plate re-organisation of spreading and enhanced tectonomagmatic activity in the Mohn's Ridge region (between about $6 \mathrm{Ma}$ and 5 Ma: Géli, 1991).

- Anomaly 3: 6 - 5 Ma (CRF 24) - Increase of volcanism in the East Central North Atlantic domain (from about 5 Ma: Schmincke, 1982).

- Anomaly 2A: 4 - 3 Ma (CRF 25) - Plate re-organisation along the entire Atlantic seafloor spreading system (Klitgord \& Schouten, 1986). Uplift of the Reykjanes Ridge (from about $3.5 \mathrm{Ma}$ to $2 \mathrm{Ma}$ ) and abyssal circulation change (about 3 - $2 \mathrm{Ma}$ : Tucholke \& Mountain, 1986).

\section{Conclusion}

This study indicates that, in general, the Alpine, Mediterranean and North Atlantic tectonic events which affected the Tertiary development of basins are correlative in time and causally related through the regional interactions and re-organisations of the African, Iberian, Apulian and European plates (Figs 21 to 28; Encls 3 to 8 ). This general conclusion is considerably strengthened if discrepancies in dating on the order of $0.5-1 \mathrm{Ma}$ are considered as insignificant. Obviously, further investigation and corroboration of the ages and correlations of the Alpine Foreland events and the Mediterranean and Atlantic plateboundary events is still needed. From the mid-Rupelian 
onwards, polyphase slab roll-back subduction and occasional detachment of the Maghrebian-Apenninic lithospheric slab occurred, inducing episodic, eastward progressing back-arc extension in the western Mediterranean (Figs 4, 9, 25 and 27). This major formative process was interrupted by repeated compression and extension induced during the kinematic evolution of the African-European plate assembly. Timeequivalent imprints of these events are recorded in the sedimentary fills of the Alpine Foreland basins and the basins of the western Mediterranean. Kinematic activity of the northern Mid-Atlantic Ridge system (governed by North Atlantic ridge-push forces) and the African-Apulian-Iberian plate assembly (governed by Indian and South Atlantic ridgepush forces) and the coeval tectonosedimentary changes in the Alpine-Mediterranean plate-boundary basins (governed by African/Apulian collision forces) were geodynamically coupled through the $\mathrm{S}$ to $\mathrm{N}$ progression of the opening of the Atlantic Ocean and its subsequent structural development, and the N-S convergence of Africa and Europe (Figs 2 and 3). Accordingly, the Alpine-Mediterranean tectonosedimentary sequences ultimately reflect activity along seafloor spreading axes (governed by ridge-push forces).

Sequence stratigraphic correlations imply a causal relationship between tectonic and sedimentary responses in the Alpine-Mediterranean region and plate-boundary events in the northern Mid-Atlantic Ridge system and along the northern edge of the African Plate. However, conclusive proof of isochroneity of the correlations is beyond the resolution of the current dating methods. In most cases, the responses probably reflect changes in the motion of Africa relative to Europe. The main signal events are (Fig. 28):

- CRF 1 (60 - $59 \mathrm{Ma}$ ) . Formation of the Azores-Biscay Rise Opening of the Alpine Foredeep

- CRF 2 (56 - $55 \mathrm{Ma}$ ) . Opening of the Norwegian-Greenland Sea

- CRF 3 (50-49 Ma) Formation of the King's TroughAzores-Biscay Rise-North Spanish Trough Fracture Zone

- Opening of the European Cenozoic Rift System

- CRF 4 (42 - $41 \mathrm{Ma})$ - Iberia becomes independent from Africa and Europe

- Peak of HP Adamello metamorphism in the Alpine orogen

- CRF 5 (39 - $38 \mathrm{Ma}$ ) . Onset of the main rifting phases in the Rhine and Rhône grabens

Peak of HP Lepontine metamorphism in the Alpine orogen

- CRF 8 (35 - 34 Ma) . Compression and subduction of the North Spanish Trough

- Opening of the Alpine Molasse Basin
- CRF $10(33-32 \mathrm{Ma}) \cdot$ 0nset of slab roll-back subduction and back-arc extension in the western Mediterranean Basin

- End of the main phase of rifting in the Rhine and Rhône grabens

- Peak of HT Lepontine metamorphism in the Alpine orogen

- Onset of thrusting along the North Giudicarie Fault (Insubric Line)

- CRF 14 (24 - $23 \mathrm{Ma}) \cdot$ Iberia becomes part of Europe again

- CRF 16 (22 - $21 \mathrm{Ma})$ - Onset of oceanisation of the AlgéroProvençal Basin

. End of rifting in the Rhône Graben.

Based on current datings, some regional CRF phases are synchronous with, but not necessarily causally related to, global changes of climate. These are driven, or triggered, by tectonic processes, orbital rhythms and so-called aberrations, i.e. brief and effective anomalous developments standing out well above the normal background variability (Zachos et al., 2001). The following listing highlights the correlation between short-lived tectonostratigraphic phases in Western Europe and abrupt changes in Earth's climate. Despite the chronostratigraphic correlations, the cause of the climate changes remains a matter of debate (ages after Zachos et al., 2001):

- CRF 1: Onset of pronounced warming event (59 Ma)

- CRF 2: Late Paleocene Thermal Maximum (55 Ma)

- CRF 3: End of Early Eocene Climatic Optimum (50 Ma)

- CRF 4: Middle Eocene Climatic 0ptimum (41.5 Ma: Bohaty \& Zachos., 2003)

- CRF 5: Appearance of small-ephemeral ice sheets in the Southern Hemisphere (between $36 \mathrm{Ma}$ and $38 \mathrm{Ma}$ )

- CRF 8: Early Oligocene Glaciation (35-34 Ma)

- CRF 12: Oligocene Glacial Maximum, succeeded by the Late Oligocene Warming Event (27 - $26 \mathrm{Ma}$ )

- CRF 14: Early Miocene Glaciation (24 - 23 Ma)

- CRF 18: Mid-Miocene Climatic 0ptimum (17 - $15 \mathrm{Ma}$ )

- CRF 20: East Antarctic ice-sheet expansion ( 12 - $10 \mathrm{Ma}$ )

- Between CRF 23 and CRF 24: West Antarctic ice-sheet expansion (6 $\mathrm{Ma}$ )

- CRF 25: Onset of glaciation in the Northern Hemisphere ( 3.2 Ma)

Given the assumption of long-distance correlations of tectonic events (Figs 23 and 25 to 28; Encls 7 and 8) and the (partial) plate-kinematic control on the sequence stratigraphy of the Alpine Foreland basins, the following concepts are plausible:

1. Isochronous syn-kinematic correlation of stress regimes and depositional changes - The crustal properties of the AfricaApulia-Iberia-Europe plate assembly allowed collisional stress to be transmitted over great distances across 
convergent plate boundaries, generally with relatively homogeneous directions of the maximum horizontal stresses. Accompanying compression from the MediterraneanAtlantic domains affected large parts of the Alpine Foreland. Temporally, the far-field, kinematically-induced changes of the stress regime and associated tectonosedimentary settings occurred simultaneously. However, depending on relative plate setting, this results in possibly different correlative 'stress-field facies'. This is analogous to Walther's 'law of isochronous correlation of different sedimentary facies'. Areally, changes in stress regime across plate boundaries were causally linked.

2. Intermittent syn-kinematic detachment of subducted slabs The timing of the Maghrebian, Apenninic and Alpine slab detachments was influenced by compressional platekinematic interactions associated with the convergence of Africa and Europe. The syn-collisional break-off of mechanically weakened subducting lithosphere (e.g. by exceeding its strength through gravitational slab-pull extension) may have been triggered by a change in convergence rate and/or convergence direction via a change in the state of stress of the slab. At upper crustal levels above the line of slab break-off, the sedimentary development of the Alpine Foreland and western Mediterranean basins was probably affected (almost) instantaneously upon slab detachment. The decrease of the slab-pull force induced by the sinking of the detached slab into the mantle increased the buoyancy of the shallow part of the slab and induced rebound uplift of the crust. The occurrence of coeval geological imprints at great distance from the zone of slab detachment indicates the likely occurrence of a brief collisional event at the convergent plate boundary. Consequently, lithosphere rupture (lithosphere tearing, slab detachment) may have been an important process in determining the tectonostratigraphic architecture of basins.

3. Punctuated syn-kinematic development of plate-boundary basins - 0verall, the basins of the Alpine Foreland and western Mediterranean developed under influence of longterm geological processes such as persistent flexuring, rifting and sediment loading. This study shows that these processes were repeatedly interrupted or modified by brief tectonic events related to punctuated plate-kinematic forcing of the evolving African-Apulian-Iberian-European plate assembly. These events appear to be also correlative to changes in eustatic sea level. Thus, the sequence stratigraphic development of the Alpine-Mediterranean plateboundary basins was probably controlled by coeval, episodic changes in plate-kinematics and eustacy. In other words, the shorter-term, kinematics-related evolution of these basins presumably proceeded under combined tectonic and eustatic control.

\section{Acknowledgements}

The author thanks J.F. Dewey (University of California, Davis) and J. Kuhlemann (University of Tübingen) for their stimulating and constructive comments upon an earlier version of the manuscript. This paper benefited also from critical comments by C.J. van der Zwan (SIEP-RTS, Rijswijk) and W.J.E. van de Graaff (Rijswijk). Special thanks are due to J.J.J. Bergenhenegouwen and J.M. Santoe (Faculty of Earth Sciences, Utrecht University) for drawing the illustrations. The reconstruction of the plate-tectonic drift of Apulia relative to Europe (Fig. 3) is based on calculations carried out by M. de Jonge (previously Faculty of Earth Sciences, Utrecht University). His contribution is gratefully acknowledged as well. This is publication number NSG 2006.04.01 of the Netherlands Research School of Sedimentary Geology.

\section{References}

Aïte, M.O.R., 1995. Paléoconstraintes post-collision identifiées dans le Néogène de Grande Kabylie (Algérie). Comptes Rendus de l'Académie des Sciences (Paris) 2a, 320:433-438.

Albarello, D., Mantovani, E., Babbucci, D. \& Tamburelli, C., 1995. Africa-Eurasia kinematics: main constraints and uncertainties. Tectonophysics 243: 25-36.

Allen, P.A., Crampton, S.L. \& Sinclair, H.D., 1991. The inception and early evolution of the North Alpine Foreland Basin, Switzerland. Basin Research 3: 143-163.

Alvaro, M., 1987. La tectónica de cabalgamientos de la Sierra Norte de Mallorca (Islas Baleares). Boletin Geologico y Minero 98: 622-629.

Alvaro, M., Barnolas, A., del Olmo, P., Raminez del Pozo, J. \& Simo, A., 1984. El Neógeno de Mallorca: caracterización sedimentológica y bioestratigráfica. Boletin Geologico y Minero 95: 3-25.

Andeweg, B., 2003. Cenozic Tectonic Evolution of the Iberian Peninsula: Causes and Effects of Changing Stress Fields. Ph. D. Thesis Free Univ. (Amsterdam): 177 pp. Internet: http://www. geo.vu.nl/ andb/iberia.

Andeweg, B. \& Cloetingh, S., 1998. Flexure and 'unflexure' of the North Alpine German-Austrian Molasse Basin: constraints from forward modelling. Geological Society Special Publication (London) 134: 404-422.

Argnani, A. \& Savelli, C., 1999. Cenozoic volcanism and tectonics in the southern Tyrrhenian sea: space-time distribution and geodynamic significance. Geodynamics 27: 409-432.

Assorgia, A., Barca, S. \& Spano, C., 1997. A synthesis on the Cenozoic stratigraphic, tectonic and volcanic evolution in Sardinia (Italy). Bollettino della Societa Geologica Italiana 116: 407-420.

Banda, E. \& Santanach, P., 1992. The Valencia trough (western Mediterranean): an overview. Tectonophysics 203: 183-202.

Bartole, R., 1995. The North Tyrrhenian-Northern Apennines post-collisional system: constraints for a geodynamic model. Terra Nova 7: 7-30.

Bartrina, M.T., Cabrera, L., Jurado, M.J., Guimerà \& Roca, E., 1992. Evolution of the central Catalan margin of the Valencia trough (western Mediterranean). Tectonophysics 203: 219-247. 
Beccaluva, L., Brotzu, P., Macciotta, G., Morbidelli, L., Serri, G. \& Traversa, G., 1989. Cainozoic tectono-magmatic evolution and inferred mantle sources in the Sardo-Tyrrhenian area. Atti Convegni Lincei 80: 229-248.

Bellon, H., 1981. Chronologie radiométrique (K-Ar) des manifestations magmatiques autour de la Méditerranée occidentale entre 33 et 1 Ma. NATO Asi Series 402: 341-360.

Bellon, H., Bordet, P. \& Montenat, C., 1983. Chronologie du magmatisme néogène des Cordillères bétiques (Espagne méridionale). Bulletin de la Société Géologique de France 7, 25: 205-217.

Benammi, M., Orth, B., Vianey-Liaud, M., Chaimanée, Y., Suteethorn, V., Feraud, G., Hernán, J. \& Jaeger, J.J., 1995. Micromammifères et biochronologie des formations néogènes du flanc sud du Haut-Atlas Marocain: implications biogéographiques, stratigraphiques et tectoniques. Africa Geoscience Review 2: 279-310.

Bergerat, F., 1987a. Stress fields in the European platform at the time of African-Eurasia collision. Tectonics 6: 99-132.

Bergerat, F., 1987b. Paléo-champs de constrainte tertiaires dans la plate-forme européenne au front de l'orogène alpin. Bulletin de la Société Géologique de France 8, 3: 611-620.

Berggren, W.A. \& Olsson, R.K., 1986. North Atlantic Mesozoic and Cenozoic paleobiogeography. In: Vogt, P.R. \& Tucholke, B.E. (ed.): The Geology of North America. Geological Society of America (Boulder) M: 565-587.

Biermann, C., 1995. The Betic Cordilleras (SE Spain). Anatomy of a dualistic collision-type orogenic belt. Geologie en Mijnbouw 74: 167-182.

Blès, J.L. \& Gros, Y., 1991. Stress field changes in the Rhone Valley from the Miocene to the present. Tectonophysics 194: 265-277.

Blès, J.-L., Bonijoly, D., Castaing, C. \& Gros, Y., 1989. Successive post-Variscan stress fields in the French Massif Central and its borders (Western European plate): comparison with geodynamics. Tectonophysics 169: 79-111.

Boccaletti, M. \& Sani, F., 1998. Cover thrust reactivations related to internal basement involvement during Neogene-Quaternary evolution of the northern Apennines.Tectonics 17: 112-130.

Bohaty, S.M. \& Zachos, C., 2003. A significant Southern Ocean warming event in the late middle Eocene. Geology 31: 1017-1020.

Bois, C., 1993. Initiation and evolution of the Oligocene-Miocene rift basins of southwestern Europe: contribution of deep seismic reflection profiling. Tectonophysics 226: 227-252.

Brouwer, F.M., 2000. Thermal evolution of high-pressure metamorphic rocks in the Alps. Geologica Ultraiectina 199: $221 \mathrm{pp}$.

Brunet, C., Monié, P., Jolivet, L. \& Cadet, J.-P., 2000. Migration of compression and extension in the Tyrrhenian Sea, insights from 40Ar/39Ar ages on micas along a transect from Corsica to Tuscany. Tectonophysics 321: 127-155.

Burrus, J., 1984. Contribution to a geodynamic synthesis of the Provençal Basin (northwestern Mediterranean). Marine Geology 55: 247-269.

Calvo, J.P., Daams, R., Morales, J., Lopez-Martinez, N., Agusti, J., Anadon, P., Armenteros, I., Cabrera, L., Civis, J., Corrochano, A., Diaz-Molina, M., Elizaga, E., Hoyos, M., Martin-Suarez, E., Martinez, J., Moissenet, E., Muñoz, A., Perez-Garcia, A., Portero, J.M., Robles, F., Santisteban, C., Torres, T., van der Meulen, A.J., Vera, J.A. \& Mein, P., 1993. Up-to-date Spanish continental synthesis and paleoclimatic interpretation. Revista de la Sociedad Geologica de España 6: 31-40.

Campos, J, Maldonado, A. \& Campillo, A.C., 1992. Post-Messinian evolutionary patterns of the central Alboran Sea. Geo-Marine Letters. 12: 173-178.
Carmignani, L., Decandia, F.A., Disperati, L., Fantozzi, P.L., Lazzarotto, A., Liotta, D. \& Oggiano, G., 1995. Relationships between the Tertiary structural evolution of the Sardinia-Corsica-Provençal domain and the Northern Apennines. Terra Nova 7: 128-137.

Carminati, E., Wortel, M.J.R., Spakman, W. \& Sabadin, R., 1998a. The role of slab detachment processes in the opening of the western-central Mediterranean basins: some geological and geophysical evidence. Earth and Planetary Science Letters 160: 651-665.

Carminati, E., Wortel, M.J.R., Meijer, P.T. \& Sabadin, R., 1998b. The twostage opening of the western-central Mediterranean basins: a forward modeling test to a new evolutionary model. Earth and Planetary Science Letters 160: 667-679.

Casula, G., Cherchi, A., Montadert, L. Murru, M. \& Sarria, E., 2001. The Cenozoic graben system of Sardinia (Italy): geodynamic evolution from new seismic and field data. Marine and Petroleum Geology 18: 863-888.

Chalouan, A., Saji, R., Michard, A. \& Bally, A.W., 1997. Neogene tectonic evolution of the southwestern Alboran Basin from seismic data offshore Morocco. American Association of Petroleum Geologists Bulletin 81: 1161-1184.

Chamot-Rooke, N., Jestin, F. \& Gaulier, J.-M., 1997. Constraints on Moho depth and crustal thickness in the Liguro-Provençal Basin from a 3D gravity inversion: geodynamic implications. Revue de $l^{\prime}$ Institut Français du Pétrole 52: 557-583.

Chamot-Rooke, N., Gaulier, J.-M. \& Jestin, F., 1999. Constraints on Moho depth and crustal thickness in the Liguro-Provençal basin from a 3D gravity inversion: geodynamic implications. Geological Society Special Publication (London) 156: 37-61.

Cherchi, A. \& Montadert, L., 1982. The Oligo-Miocene rift of Sardinia and the early history of the western Mediterranean Basin. Nature 298: 736-739.

Cherchi, A. \& Trémolières, P., 1984. Nouvelles données sur l'évolution structurale au Mésozoique et au Cénozoïque de la Sardaigne et leurs implications géodynamiques dans le cadre méditerranéen. Comptes Rendus de l'Académie des Science (Paris) 2, 298: 889-894.

Chorowicz, J. \& Deffontaines, B., 1993. Transfer faults and pull-apart model in the Rhine graben: from analysis to multisource data. Journal of Geophysical Research 98 B8: 14339-14351.

Cipollari, P. \& Cosentino, D., 1995. Il sistema Tirreno-Appennino: segmentazione litosferica e propagazione del fronte compressivo. Studi Geologici Camerti: Volume Speciale 2:125-134.

Clavell, E. \& Berastegui, X., 1991. Petroleum geology of the Gulf of Valencia. Special Publication of the European Association of Petroleum Geologists 1: 355-368.

Cloetingh, S., 1986. Intra-plate stresses: a new tectonic mechanism for fluctuations of relative sea level. Geology 14: 617-620.

Cloetingh, S., Van der Beek, P.A., Van Rees, D., Roep, T.B., Biermann, C. \& Stephenson, R.A., 1992. Flexural interaction and the dynamics of Neogene extensional basin formation in the Alboran-Betic region. Geo-Marine Letters 12: 66-75.

Comas, M.C., García-Dueñas, V. \& Jurado, M.J., 1992. Neogene tectonic evolution of the Alboran Sea from MCS data. Geo-Marine Letters 12: 157-164.

Comas, M.C., Platt, J.P., Soto, J.I. \& Watts, A.B., 1999. The origin and tectonic history of the Alboran Basin: insights from Leg 161 results. Proceedings of the 0cean Drilling Program: Scientific Results 161: 555-580. 
Dañobeitia, J.J., Alonso , B. \& Maldonado, A., 1990. Geological framework of the Ebro continental margin and surrounding areas. Marine Geology 95: 265-287.

Dañobeitia, J.J., Arguedas, M., Gallart, J., Banda, E. \& Makris, J., 1992. Deep crustal configuration of the Valencia trough and its Iberian and Balearic borders from extensive refraction and wide-angle reflection seismic profiling. Tectonophysics 203: 37-55.

De Jong, K., Wijbrands, J.R. \& Féraud, G., 1992. Repeated thermal resetting of phengites in the Mulhacen Complex (Betic Zone, southeastern Spain) shown by 40Ar/3-9Ar step heating and single grain laser probe dating. Earth and Planetary Science Letters 110: 173-191.

De Ruig, M.J., 1992. Tectono-sedimentary evolution of the Prebetic fold belt of Alicante (SE Spain): a study of stress fluctuations and foreland basin deformation. Ph.D. Thesis Free Univ. (Amsterdam): 207 pp.

De Ruig, M.J., Smit, J., Geel, T. \& Kooi, H., 1991. Effects of the Pyrenean collision on the Paleocene stratigraphic evolution of the southern Iberian margin. Geological Soceiety of America Bulletin 103: 1504-1512.

Dewey, J.F., Helman, M.L., Turco, E., Hutton, D.H.W. \& Knott, S.D., 1989. Kinematics of the western Mediterranean. Geological Society Special Publication (London) 45: 265-283.

Dèzes, P., Schmid, S.M. \& Ziegler, P.A., 2004. Evolution of the European Cenozoic Rift System: interaction of the Alpine and Pyrenean orogens with foreland lithosphere. Tectonophysics 389: 1-33.

Di Battistini, G., Toscani, S., Iaccarino, S. \& Villa, I., 1987. K/Ar ages and the geological setting of calc-alkaline volcanic rocks from Sierra de Gata, SE Spain. Neues Jahrbuch für Mineralogie: Monatshefte 8: 369-383.

Dillon, W.P., Robb, J.M., Gary Greene, H. \& Lucena, C. J., 1980. Evolution of the continental margin of southern Spain and the Alboran Sea. Marine Geology 36: 205-226.

Doglioni, C., Gueguen, E., Sàbat, F. \& Fernàndez, M., 1997. The western Mediterranean extensional basins and the Alpine orogen. Terra Nova 9: 109112.

Doglioni, C., Fernàndez, M., Gueguen, E. \& Sàbat, F., 1999. On the interference between the early Apennines-Maghrebides backarc extension and the AlpsBetics orogen in the Neogene geodynamics of the western Mediterranean. Bollettino della Societa Geologica Italiana 118: 75-89.

Duermeijer, C.E. \& Langereis, C.G., 1998. Astronomical dating of a tectonic rotation on Sicily and consequences for the timing and extent of a middle Pliocene deformation phase. Tectonophysics 298: 243-258.

Duermeijer, C.E., van Vugt, N., Langereis, C.G., Meulenkamp, J.E. \& Zachariasse, W.J., 1998. A major late Tortonian rotation phase in the Crotone Basin using AMS as tectonic tilt correction and timing of the opening of the Tyrrhenian Sea. Tectonophysics 287: 233-249.

Edel, J.-B., Dubois, D., Marchant, R., Hernandez, J. \& Cosca, M., 2001. La rotation miocène inférieur $\mathrm{du}$ bloc corsosarde. Nouvelles contraintes paléomagnétiques sur la fin du mouvement. Bulletin de la Société Géologique de France 172: 275-283.

Escutia, C. \& Maldonado, A., 1992. Palaeogeographic implications of the Messinian surface in the Valencia trough, northwestern Mediterranean Sea. Tectonophysics 203: 263-284.
Estévez, A., González-Donoso, J.M., Linares, D., Martín-Algarra, A., Sanz de Galdeano, C. \& Serrano, F., 1984. El cabalgamiento finiserravallense del norte de Sierra Arana (Cordillera Betica). Observaciones sobre la caracterización bioestratigráfica del Serravallense. Méditerránea: Serie de Estudios Geologicos 3: 151-173.

Fontboté, J.M., Guimerà, J., Roca, E., Sabàt, F. \& Santanach, P., 1989. Para una interpretación cinemática de la génesis de la cuenca Catalano-Balear: datos estructurales de sus márgenes emergidos. In: Libro Homenaje R. Soler. A.G.G.E.P. (Madrid): 37-51.

Fontboté, J.M., Guimerà, J., Roca, E., Sabàt, F., Santanach, P. \& FernàndezOrtigosa, F., 1990. The Cenozoic geodynamic evolution of the València trough (Western Mediterranean). Revista de la Sociedad Geologica de España 3: 249-259.

Frizon de Lamotte, D., Saint Bezar, B. \& Bracène, R., 2000. The two main steps of the Atlas building and geodynamics of the western Mediterranean. Tectonics 19: 740-761.

Galindo-Zaldivar, J., González-Lodeiro, F. \& Jabaloy, A., 1993. Stress and palaeostress in the Betic-Rif cordilleras (Miocene to the present). Tectonophysics 227: 105-126.

Geel, T., 1995. Oligocene to early Miocene tectono-sedimentary history of the Alicante region (SE Spain): implications for Western Mediterranean evolution. Basin Research 7: 313-336.

Geel, T., 2000. Recognition of stratigraphic sequences in carbonate platform and slope deposits: empirical models based on microfacies analysis of Palaeogene deposits in southeastern Spain. Palaeogeography, Palaeoclimatolology, Palaeoecology 155: 21-238.

Geel. T., Roep, T.B., ten Kate, W. \& Smit. J., 1992. Early-Middle Miocene stratigraphic turning points in the Alicante region (SE Spain): reflections of Western Mediterranean plate-tectonic reorganizations. Sedimentary Geology 75: 223-239.

Geel, T., Roep, T.B., van Hinte, J.E. \& Vail, P.R., 1998. Eocene tectonosedimentary patterns in the Alicante region (southeastern Spain). Special Publication of the Society for Sedimentary Geology 60: 298-302.

Gelabert, B., Sàbat, F. \& Rodriquez-Perea, A., 1992. A structural outline of the Serra de Tramuntana of Mallorca (Balearic Islands). Tectonophysics 203: 167-183.

Gélard, J.-P., 1979. Géologie du Nord-est de la Grande Kabylie (un segment des zones internes de l'orogène littoral maghrebin). Mémoires Géologiques de l'Université de Dijon 5: 335 pp.

Géli, L., 1991. Étude de la dorsale de Mohn, au voisinage de $72 \infty \mathrm{N}$, en Mer de Norvège et du Groenland. Comptes Rendus de l'Académie des Sciences (Paris) 2, 313: 1291-1300, 1569-1578.

Gölke, M. \& Coblentz, D., 1996. Origins of the European regional stress field. Tectonophysics 266: 11-24.

Gorini, C., Le Marrec, A. \& Mauffret, A., 1993. Contribution to the structural and sedimentary history of the Gulf of Lions (western Mediterranean), from the ECORS profiles, industrial seismic profiles and well data. Bulletin de la Société Géologique de France 164: 353-363.

Grünthal, G. \& Stromeyer, D., 1986. Stress pattern in Central Europe and adjacent areas. Gerlands Beiträge zur Geophysik 95: 443-452.

Gueguen, E., Doglioni, C. \& Fernàndez, M., 1997. Lithospheric boudinage in the western Mediterranean back-arc basin. Terra Nova 9: 184-187. 
Guennoc, P., Debeglia, N., Gorini, C., Le Marrec, A. \& Mauffret, A., 1994. Anatomie d'une marge passive jeune (Golfe du Lion - sud France): apports des données géophysique. Bulletin des Centres de Recherches ExplorationProduction Elf Aquitaine 18: 33-57.

Guennoc, P., Gorini, C. \& Mauffret, A., 2000. Histoire géologique du golfe du Lion et cartographie du rift oligo-aquitanien et de la surface messinienne. Géologie de France 3: 67-97.

Guerrera, F., Martin-Algarra, A. \& Perrone, V., 1993. Late Oligocene-Miocene syn-/late-orogenic successions in Western and Central Mediterranean Chains from the Betic Cordillera to the Southern Apennines. Terra Nova 5: 525-544.

Haq, B.U., Hardenbol, J. \& Vail, P.R., 1988. Mesozoic and Cenozoic chronostratigraphy and cycles of sea-level change. Special Publication of the Society of Economic Paleontologists and Mineralogists 42: 71-108.

Harland, W.B., Armstrong, R.L., Cox, A.V., Craig, L.E., Smith, A.G. \& Smith, D.G., 1990. A Geologic Time Scale 1989. Cambridge University. Press (Cambridge): $263 \mathrm{pp}$.

Hernán, J., Dominique, F., de Larouzière, D. \& Bolze, J., 1987. Le magmatisme néogène béticorifain et le couloir de décrochement trans-Alboran. Bulletin de la Société Géologique de France 8, 3: 257-267.

Hippolyte, J.-C., Angelier, J., Bergerat, F., Nury, D. \& Guieu, G., 1993. Tectonic-stratigraphic record of paleostress time changes in the 0ligocene basins of the Provence, southern France. Tectonophysics 226: 15-35.

Hippolyte, J.-C., Angelier, J. \& Roure, F., 1994. A major change revealed by Quaternary stress patterns in the Southern Apennines (Italy). Tectonophysics 230: 199-210.

Illies, J.H., Baumann, H. \& Hoffers, B., 1981. Stress pattern and strain release in the Alpine foreland. Tectonophysics 71: 157-172.

Jakni, B., Poupeau, G., Sosson, M., Rossi, P., Ferrandi, J. \& Guennoc, P. 2000. Dénudations cénozoïques en Corse: une analyse thermochronologique par traces de fission sur apatites. Comptes Rendus de l'Académie des Sciences (Paris) IIa, 331: 775-782.

Janssen, M.E., Torné, M., Cloetingh, S. \& Banda, E., 1993. Pliocene uplift of the eastern Iberian margin: inferences from quantitative modelling of the Valencia Trough. Earth and Planetary Sciences Letters 119: 585-597.

Jurado, M.J. \& Comas, M.C., 1992. Well log interpretation and seismic character of the Cenozoic sequence in the northern Alboran Sea. Geo-Marine Letters 12: 129-136.

Kälin, D., 1993. Stratigraphie und Säugetierfaunen der Oberen Süsswassermolasse der Nordschweiz. PH.D. Thesis ETH Zürich: 238 pp.

Kasinski, J.R., 1991. Tertiary lignite-bearing lacustrine facies of the Zittau Basin Ohr'e rift system (Poland, Germany and Czechoslovakia). Special Publication of the International Association of Sedimentologists 13: 93-107.

Kempf, 0. \& Matter, A., 1999. Magnetostratigraphy and depositional history of the Upper Freshwater Molasse (OSM) of eastern Switzerland. Eclogae Geologicae Helvetiae 92: 97-103.

Kempf, O., Matter, A., Burbank, D.W., Mange, M., 1999. Deposition and structural evolution of a foreland basin margin in a magnetostratigraphic framework: the eastern Swiss Molasse Basin. International Journal of Earth Sciences 88: 253-275.

Kenter, J.A.M., Reymer, J.J., van der Straaten, H.C. \& Peper, T., 1990. Facies patterns and subsidence history of the Jumilla-Cieza region (southeastern Spain). Sedimentary Geology 67: 263-280.
Kidd, R.B. \& Ramsay, A.T.S., 1986. The geology and formation of the King's Trough complex in the light of Deep Sea Drilling Project site 608 drilling. Initial Reports DSDP 94: 1245-1261.

Kidd, R.B., Searle, R.C., Ramsay, A.T.S., Prichard, H. \& Mitchell, J., 1982. The geology and formation of King's Trough, northeast Atlantic 0cean. Marine Geology 48: 1-30.

Klitgord, D. \& Schouten, H., 1986. Plate kinematics of the central Atlantic. In: Vogt, P.R. \& Tucholke, B.E. (ed.): The Geology of North America. Geological Society of America (Boulder) M: 351-378.

Krijgsman, W., Hilgen, F.J., Raffi, I., Sierro, F.J. \& Wilson, D.S., 1999a. Chronology, causes and progression of the Messinian salinity crisis. Nature 400: 652-655.

Krijgsman, W., Langereis, C.G., Zachariasse, W.J., Boccaletti, M., Moratti, G., Gelati, R., Iaccarino, S., Papani, G. \& Villa, G., 1999b. Late Neogene evolution of the Taza-Guercif Basin (Rifian Corridor, Morocco) and implications for the Messinian salinity crisis. Marine Geology 153: 147-160.

Kuhlemann, J. \& Kempf, 0., 2002. Post-Eocene evolution of the North Alpine Foreland Basin and its response to Alpine tectonics. Sedimentary Geology 152: $45-78$.

Kuhlemann, J., Frisch, W., Dunkl, I. Székely, Spiegel, C., 2001. Miocene shifts of the drainage divide in the Alps and their foreland basin. Zeitschrift für Geomorphologie, new ser., 45: 239-265.

Lacombe, O., Angelier, J., Byrne, D. \& Dupin, J.-M., 1993. Eocene-0ligocene tectonics and kinematics of the Rhine-Saône continental transform zone (eastern France). Tectonics 12: 874-888.

Laubscher, H., 1992. Jura kinematics and the Molasse Basin. Eclogae Geologicae Helvetiae 85: 653-675.

Laubscher, H., Biella, G.C., Cassinis, R., Lozej, A., Scarascia, S. \& Tabacco, I., 1992. The collisional knot in Liguria. Geologische Rundschau 81: 275-289.

Le Pichon, X., Bergerat, F. \& Roulet, M.-J., 1988. Plate kinematics and tectonics leading to the Alpine belt formation: a new analysis. Geological Society of America Special Publication 218: 11-131.

Lepvrier, C. \& Martínez-Garcia, E., 1990. Fault development and stress evolution of the post-Hercynian Asturian Basin (Asturias and Cantabria, northwestern Spain). Tectonophysics 184: 345-356.

Letouzey, J., 1986. Cenozoic paleo-stress pattern in the Alpine foreland and structural interpretation in a platform basin. Tectonophysics 132: 215-231.

Letouzey, J. \& Trémolières, P., 1980. Paleo-stress fields around the Mediterranean since the Mesozoic derived from microtectonics: comparisons with plate tectonic data. Mémoires du Bureau de Recherches Géologiques et Minières 115: 261-273.

Lonergan, L. \& White, N., 1997. Origin of the Betic mountain chain. Tectonics 16: 504-522.

Mailhe, D., Carpena, J. \& Poupeau, G., 1980. Fission-track age of the last Alpine tectonometamorphic event in Corsica. Proc. Symp. Evolution and Tectonics of the Western Mediterranean and Surrounding Areas. Instituto Geografico Nacional: Special Publication 201: 149-162.

Maillard, A., Mauffret, A., Watts, A.B., Torné, M., Pascal, G., Buhl, P. \& Pinet, B., 1992. Tertiary sedimentary history and structure of the Valencia trough (western Mediterranean). Tectonophysics 203: 57-75.

Malinverno, A. \& Ryan, B.F., 1986. Extension in the Tyrrhenian Sea and shortening in the Apennines as result of arc migration driven by sinking of the lithosphere. Tectonics 5: 227-245. 
Mantovani, E., Albarello, D., Babbucci, C. \& Tamburelli, C., 1993. PostTortonian deformation pattern in the Central Mediterranean: a result of extrusion tectonics driven by the African-Eurasia convergence. NAT0 Asi Series C 402: 65-104.

Marti, J., Mitjavila, J., Roca, E. \& Aparicio, A., 1992. Cenozoic magmatism of the Valencia trough (western Mediterranean): relationship between structural evolution and volcanism. Tectonophysics 203: 145-165.

Martín-Algarra, A., Sanz de Galdeano, C. \& Estévez, A., 1988. L'évolution sédimentaire miocène de la région au nord de la Sierra Arana (Cordillères bétiques) et sa relation avec la mise en place du bloc d'Alboran. Bulletin de la Société Géologique de France 8, 4: 119-127.

Márton, E., Kuhlemann, J. Frisch, W. \& Dunkl, I., 2000. Miocene rotations in the Eastern Alps - palaeomagnetic results from intramontane basin sediments. Tectonophysics 323: 163-182.

Mascle, J., Karsten, K., Auroux, C. \& Leg 107 Scientific Party, 1988. A landlocked back-arc basin: preliminary results from ODP Leg 107 in the Tyrrhenian Sea. Tectonophysics 146: 149-162.

Mauffret, A., Frizon de Lamotte, D., Lallemant, S., Gorini, C. \& Maillard, A., 2004. E-W opening of the Algerian Basin (Western Mediterranean). Terra Nova 16: 257-264.

Mazzoli, S. \& Helman, M., 1994. Neogene patterns of relative plate motion for Africa-Europe: some implications for recent central Mediterrenean tectonics. Geologische Rundschau 83: 464-468.

Meulenkamp, J.E. \& Sissingh, W., 2003. Tertiary palaeogeography and tectonostratigraphic evolution of the Northern and Southern Peri-Tethys platforms and the intermediate domains of the African-Eurasian convergent plate boundary zone. Palaeogeography, Palaeoclimatology, Palaeoecology 196: 209-228.

Miller, K.G. \& Fairbanks, R.G., 1985. Oligocene to Miocene carbon isotopic cycles and abyssal circulation changes. Geophysical Monograph 32: 469-486.

Mitjavila, J., Ramos-Guerrero, E. \& Marti, J., 1990. Les roches pyroclastiques du Puig de l'Ofre (Serra de Tramuntana, Majorque): position géologique et datation K-Ar. Comptes Rendus de l'Académie des Sciences (Paris) 2, 311: 687-692.

Monié, P., Maluski, H., Saadallah, A. \& Caby, R., 1988. New 39Ar-40Ar ages of Hercynian and Alpine thermotectonic events in Grande Kabylie (Algeria). Tectonophysics 152: 53-69.

Monié, P., Galindo-Zaldívar, J., González Lodeiro, F., Goffe, B. \& Jabaloy, A., 1991. 40Ar/39Ar geochronology of Alpine tectonism in the Betic Cordilleras (southern Spain). Journal of the Geological Society (London) 148: 289-297.

Monié, P., Torres-Roldán, R.L. \& Garciá-Casco, A., 1994. Cooling and exhumation of the Western Betic Cordilleras, $40 \mathrm{Ar} / 39 \mathrm{Ar}$ thermochronological constraints on a collapsed terrane. Tectonophysics 238: 353-379.

Monleau, C., Arnaud, M. \& Catzigras, F., 1988. L'Oligocène supérieur marin de la Nerthe (Bouches-du-Rhône): nouvelles données sédimentologiques et paléogéographiques, dans le cadre de la géodynamique de la Méditerranée occidentale. Comptes Rendus de l'Académie des Sciences (Paris) 2, 306: 487-491.

Montenat, C., Ott d'Estevou, P., de Larouzière, F.D. \& Bedu, P., 1987. Originalité géodynamique des bassins du domaine bétique oriental. Notes et Mémoires Total Compagnie Francaise Pétroles 21: 11-49.
Morra, V., Secchi, F.A. \& Assorgia, A., 1994. Petrogenetic significance of peralkaline rocks from Cenozoic calc-alkaline volcanism from SW Sardinia, Italy. Chemical Geology 118: 109-142.

Morra, V., Secchi, F.A.G., Melluso, L. \& Franciosi, L., 1997. High-Mg subduction-related Tertiary basalts in Sardinia, Italy. Lithos 40: 69-91.

Morton, A.C. \& Parson, L.M., 1988. Early Tertiary Volcanism and the Opening of the NE Atlantic. Geological Society Special Publication (London) 39: XII $+477 \mathrm{pp}$.

Müller, B., Zoback, M.L., Fuchs, K., Mastin, L., Gregersen, S., Pavoni, N., Stephansson, 0. \& Ljunggren, C., 1992. Regional patterns of tectonic stress in Europe. Journal of Geophysical Research 97 B8: 11783-11803.

Müller, B., Wehrle, V., Zeyen, H. \& Fuchs, K., 1997. Short-scale variations of tectonic regimes in the western European stress province north of the Alps and Pyrenees. Tectonophysics 275: 199-219.

Müller, W., Prosser, G., Mancktelow, N.S., Villa, I.M., Kelley, S.P., Viola, G. \& Oberli, F., 2001. Geochronological constraints on the evolution of the Periadriatic Fault System (Alps). International Journal of Earth Sciences 90: 623-653.

Nelson, C.H. \& Maldonado, A., 1990. Factors controlling late Cenozoic continental margin growth from the Ebro Delta to the western Mediterranean deep sea. Marine Geology 95: 419-440.

Odin, G.S., Assorgia, A., Barca, S., Porcu, A., Spano, C., Hernán, J. \& Cosca, M., 1994. 40Ar/39Ar geochronology of a Burdigalian tuff from central-northern Sardinia. Giornale di Geologia 3a, 56: 185-197.

Ottaviani-Spella, M.-M., Girard, M. \& Cheilletz, A., 1996. Les ignimbrites burdigaliennes du sud de la Corse. Pétrologie et datation K-Ar. Comptes Rendus de l'Académie des Sciences (Paris) 2a, 323: 771-778.

Ott d'Estevou, P., Montenat, C., Ladure, F. \& Pierson d'Audrey, L., 1988. Évolution tectono-sédimentaire du domaine prébétique oriental (Espagne) au Miocène. Comptes Rendus de l'Académie des Sciences (Paris) 2, 307: 789 796.

Parés, J.M., Freeman. R. \& Roca, E., 1992. Neogene structural development in the Valencia trough margins from palaeomagnetic data. Tectonophysics 203: 111-124.

Peresson, H. \& Decker, K., 1997. The Tertiary dynamics of the northern Eastern Alps (Austria): changing palaeostresses in a collisional plate boundary. Tectonophysics 272: 125-157.

Philip, H., 1987. Plio-quaternary evolution of the stress field in Mediterranean zones of subduction and collision. Annals of Geophysics 5B: 301-320.

Platt, J.P., Behrmann, J.H., Cunningham, P.C., Dewey, J.F., Helman, M., Parish, M., Shepley, M.G., Wallis, S. \& Weston, P.J., 1989. Kinematics of the Alpine arc and the motion history of Adria. Nature 337: 158-161.

Pomar Gomà, L., 1979. La evolución tectonosedimentaria de las Baleares: Análisis critico. Acta Geologica Hispanica 14: 293-310.

Prodehl, C., Mueller, S. \& Haak, V., 1995. The European Cenozoic rift system. Developments in Geotectonics 25: 133-211.

Ramos-Guerrero, E., Rodriquez-Perea, A., Sàbat, F. \& Serra-Kiel, J., 1989. Cenozoic tectosedimentary evolution of Mallorca island. Geodinamica Acta 3: 53-72.

Rebaï, S., Philip, H. \& Taboada, A., 1992. Modern tectonic stress field in the Mediterranean region: evidence for variation in stress direction at different scales. Geophysical Journal International 110: 106-140. 
Rehault, J.-P., Boillot, G. \& Mauffret, A., 1985. The Western Mediterranean Basin. In: Stanley, D.J. \& Wezel, F.-C. (ed.): Geological Evolution of the Mediterranean Basin. Springer (New York): 105-129.

Rehault, J.P., Moussat, E. \& Fabbri, A., 1987. Structural evolution of the Tyrrhenian back-arc basin. Marine Geology 74: 123-150.

Reichenbacher, B., 2000. Das brackisch-lakustrine Oligozän und Unter-Miozän im Mainzer Becken und Hanauer Becken: Fischfaunen, Paläoökologie, Biostratigraphie und Paläogeographie. Courier Forschungsinstitut Senckenberg 222: 1-143.

Roca, E., 2001. The Northwest-Mediterranean basin (Valencia Trough, Gulf of Lions and Liguro-Provençal basins): structure and geodynamic evolution. Mémoires du Muséum National d'Histoire Naturelle 186: 671-706.

Roca, E. \& Desegaulx, P., 1992. Analysis of the geological evolution and vertical movements in the València Trough area, western Mediterranean. Marine Petroleum Geology 9: 167-185.

Rodriguez-Fernàndez, J. \& Martín-Penela, J., 1993. Neogene evolution of the Campo de Dalias and the surrounding offshore areas - (northeastern Alboran Sea). Geodinamica Acta 6: 255-270.

Roest, W.R. \& Srivastava, S.P., 1991. Kinematics of the plate boundaries between Eurasia, Iberia, and Africa in the North Atlantic from the Late Cretaceous to the present. Geology 19: 613-616.

Sanz de Galdeano, C., 1990. Geologic evolution of the Betic Cordilleras in the Western Mediterranean, Miocene to the present. Tectonophysics 172: 107-119.

Sanz de Galdeano, C., 2000. Evolution of Iberia during the Cenozoic with special emphasis on the formation of the Betic Cordillera and its relation with the western Mediterranean. Ciências da Terra (UNL) 14: 9-24.

Sanz de Galdeano, C. \& Vera, J.A., 1992. Stratigraphic record and palaeogeographical context of the Neogene basins in the Betic Cordillera, Spain. Basin Research 4: 21-36.

Schlunegger, F., Burbank, D.W., Matter, A., Engesser, B. \& Mödden, C., 1996. Magnetostratigraphic calibration of the Oligocene to Middle Miocene (30 - 15 Ma) mammal biozones and depositional sequences of the Swiss Molasse Basin. Eclogae Geologicae Helvetiae 89: 753-788.

Schmid, S.M., Fügenschuh, B. \& Lippitsch, R., 2002. The Western Alps-Eastern Alps transition: tectonics and deep structure. Sciences Géologiques: Mémoires 54: 257-260.

Schmid, S.M., Pfiffner, O.A. \& Schreurs, G., 1997. Rifting and collision in the Penninic zone of eastern Switzerland. In: Pfiffner, 0.A., Lehner, P., Heitzmann, P., Mueller, S. \& Steck, A. (ed.): Deep Structure of the Swiss Alps. Birkhäuser Verlag (Basel): 160-185.

Schmincke, H.-U., 1982. Volcanic and chemical evolution of the Canary Islands. In: von Rad, U., Hinz, K., Sarnthein, M. \& Seibold, E. (ed.): Geology of the Northwest African Continental Margin. Springer (New York): 273-306.

Schreiber, U. \& Rotsch, S., 1998. Cenozoic block rotation according to a conjugate shear system in central Europe - indications from palaeomagnetic measurements. Tectonophysics 299: 111-142.

Schumacher, M., 2002. Upper Rhine Graben: role of preexisting structures during rift evolution. Tectonics 21: 6.1-6.17.

Séranne, M., 1999. The Gulf of Lion continental margin (NW Mediterranea) revisited by IBS: an overview. Geological Society Special Publication (London) 156: 15-36.

Simón-Gómez, J.L., 1989. Late Cenozoic stress field and fracturing in the Iberian Chain and Ebro Basin (Spain). Journal of Structural Geology 11: 285-294.
Sinclair, H.D., 1997a. Flysch to molasse transition in peripheral foreland basins: the role of the passive margin versus slab breakoff. Geology 25: 1123-1126. Sinclair, H.D., 1997b. Tectonostratigraphic model for underfilled peripheral foreland basins: an Alpine perspective. Geological Society of America Bulletin 109: 324-346.

Sinclair, H.D. \& Allen, P.A., 1992. Vertical versus horizonal motions in the Alpine orogenic wedge: stratigraphic response in the foreland basin. Basin Research 4: 215-232.

Sissingh, W., 1997. Tectonostratigraphy of the North Alpine Foreland Basin: correlation of Tertiary depositional cycles and orogenic phases. Tectonophysics 282: 223-256.

Sissingh, W., 1998. Comparative Tertiary stratigraphy of the Rhine Graben, Bresse Graben and Molasse Basin: correlation of Alpine foreland events. Tectonophysics 300: 249-284.

Sissingh, W., 2001. Tectonostratigraphy of the West Alpine Foreland: correlation of Tertiary sedimentary sequences, changes in eustatic sea-level and stress regimes. Tectonophysics 333: 361-400.

Sissingh, W., 2003a. Tertiary paleogeographic and tectonostratigraphic evolution of the Rhenish Triple Junction. Palaeogeography, Palaeoclimatology, Palaeoecology 196: 229-263.

Sissingh, W., 2003b. Stratigraphic framework of the European Cenozoic Rift System: a visual overview. Geologica Ultraiectina: Special Publication 2: 4 pp. Internet: htpp://www.igitur.nl/sissingh.

Sissingh, W., 2006. Syn-kinematic palaeogeographic evolution of the West European Platform: correlation with Alpine plate collision and foreland deformation. Netherlands Journal of Geosciences, this issue

Soler, R., Matínez del Olmo, W., Megías, A.G. \& Abéger, J.A., 1983. Rasgos basicos del Neógeno del Mediterráneo español. Méditerránea: Serie de Estudios Geologicos 1: 71-82.

Sowerbutts, A.A. \& Underhill, J.R., 1998. Sedimentary response to intra-arc extension: controls on Oligo-Miocene deposition, Sarcidano subbasin, Sardinia. Journal of the Geological Society (London) 155: 491-508.

Speranza, F., Villa, I.M, Sagnotti, L., Florindo, F., Cosentino, Cipollari, P. \& Mattei, M., 2002. Age of the Corsica-Sardinia rotation and Liguro-Provençal spreading: new paleomagnetic and Ar/Ar evidence. Tectonophysics 347: 231-251.

Srivastava, S.P. \& Tapscott, C.R., 1986. Plate kinematics of the North Atlantic. In: Vogt, P.R. \& Tucholke, B.E. (ed.): The Geology of North America. Geological Society of America (Boulder) M: 379-404

Stapel, G., Moeys, R. \& Biermann, C., 1996. Neogene evolution of the Sorbas basin (SE Spain) determined by paleostress analysis. Tectonophysics 255: 291-305.

Strunck, P. \& Matter, A., 2002. Depositional evolution of the western Swiss Molasse. Eclogae Geologicae Helvetiae 95: 197-222.

Tent-Manclús, J.E., Martín-Martín, M., Martín-Pérez \& J.A., Serrano F., 2001. Structural evolution of the early Miocene in the eastern Betic internalexternal zone boundary (SE Spain). Bulletin de la Société Géologique de France 172: 41-47.

Torné, M., Banda, E. \& Fernández, M., 1996. The Valencia Trough: geological and geophysical constraints on basin formation models. Mémoires du Muséum National d'Histoire Naturelle 170: 103-128. 
Torres, J. \& Bois, C., 1993. Deep structure and oil potential of the Valencia Trough (western Mediterranean) - contribution of deep seismic reflection profiling. First Break 11: 87-97.

Torres, J., Bois, C. \& Burrus, J., 1993. Initiation and evolution of the Valencia Trough (western Mediterranean): constraints from deep seismic profiling and subsidence analysis. Tectonophysics 228: 57-80.

Torres-Roldán, R.L., Poli, G. \& Peccerillo, A., 1986. An Early Miocene arctholeiitic magmatic dike event from the Alboran Sea - Evidence for precollisional subduction and back-arc crustal extension in the westernmost Mediterranean. Geologische Rundschau 75: 219-234.

Tucholke, B.E. \& Mountain, G.S., 1986. Tertiary paleoceanography of the western North Atlantic Ocean. In: Vogt. P.R. \& Tucholke, B.E. (ed.): The Geology of North America. Geological Society of America (Boulder) M: 631-650.

Udias, A. \& Buforn, E., 1993. Regional stresses in the Mediterranean region derived from focal mechanisms of earthquakes. NATO Asi Series C 402 : 261-268.

Uenzelmann, G., Jokat, W., Miller, H. \& Steinmetz, S., 1992. The Aegir Ridge: structure of an extinct spreading ridge. Journal of Geophysical Research 97 B6: 9203-9218.

Van der Meulen, M.J., 1999. Slab detachment and the evolution of the Appeninic arc (Italy). Geologica Ultraiectina 170: $136 \mathrm{pp}$.

Van Dijk, J.P., 1992. Late Neogene fore-arc basin evolution in the Calabrian Arc (Central Mediterranean); tectonic sequence stratigraphy and dynamic geohistory. With special reference to the geology of Central Calabria. Geologica Ultraiectina 92: 288 pp.

Van Dijk, J.P. \& Scheepers, P.J.J., 1995. Neotectonic rotations in the Calabrian Arc; implications for a Pliocene-Recent geodynamic scenario for the Central Mediterranean. Earth-Science Reviews 39: 207-246.

Vergés, J. \& Sàbat, F., 1999. Constraints on the Neogene Mediterranean kinematic evolution along a $1000 \mathrm{~km}$ transect from Iberia to Africa. Geological Society Special Publication (London) 156: 63-80.

Vially, R. \& Trémolières, P., 1996. Geodynamics of the Gulf of Lions: implications for petroleum exploration. Mémoires du Muséum National de l'Histoire Naturelle 170: 129-158.

Vigliotti, L. \& Langenheim, V.E., 1995. When did Sardinia stop rotating? New palaeomagnetic results. Terra Nova 7: 424-435.

Villéger, M. \& Andrieux, J., 1987. Phases tectoniques post-éocènes et structuration polyphasée du panneau de couverture nord provençal (Alpes externes méridionales). Bulletin de la Société Géologique de France 8, 3: 147-156.

Weltje, G., 1992. Oligocene to Early Miocene sedimentation and tectonics in the southern part of the Calabrian-Peloritan Arc (Aspromonte, southern Italy): a record of mixed-mode piggy-back basin evolution. Basin Research 4: 37-68.

Weijermars, R., 1988. Neogene tectonics in the western Mediterranean may have caused the Messinian Salinity Crisis and an associated glacial event. Tectonophysics 148: 211-219.

Wilson, M. \& Bianchini, G., 1999. Tertiary-Quaternary magmatism within the Mediterranean and surrounding regions. Geological Society Special Publication (London) 156: 141-168.

Zachos, J., Pagani, M., Sloan, L., Thomas, E. \& Billups, K., 2001. Trends, rythms, and aberrations in global climate $65 \mathrm{Ma}$ to present. Science 292: 686-693.
Zeck, H.P., 1996. Betic-Rif orogeny: subduction of Mesozoic Tethys lithosphere under eastward drifting Iberia, slab detachment shortly before $22 \mathrm{Ma}$, and subsequent uplift and extensional tectonics. Tectonophysics 254: 1-16.

Zeck, H.P., 1999. Alpine plate kinematics in the western Mediterranean: a westward-directed subduction regime followed by slab roll-back and slab detachment. Geological Society Special Publication (London) 156: 109-120.

Zeck, H.P., Albat, F., Hansen, B.T., Torres-Roldán, R.L., Garcia-Casco, A., \& Martin-Algarra, A., 1989. A $21 \pm 2$ Ma age for the termination of the ductile Alpine deformation in the internal zone of the Betic Cordilleras. Tectonophysics 169: 215-22.

Zeyen, H., Volker, F., Wehrle, V., Fuchs, K., Sobolev, S.V. \& Altherr, R., 1997. Styles of continental rifting: crust-mantle detachment and mantle plumes. Tectonophysics 278: 329-352.

Ziegler, P.A., 1988. Evolution of the Arctic-North Atlantic and the Western Tethys. American Association of Petroleum Geologists Memoir 43: 198 pp.

Ziegler, P.A., 1994. Cenozoic rift system of western and central Europe: an overview. Geologie en Mijnbouw 73: 99-127.

Ziegler, P.A., Cloetingh, S. \& van Wees, J.D., 1995. Dynamics of intra-plate deformation of the Alpine foreland and other examples. Tectonophysics 252: 7-59.

Ziegler, P.A., van Wees, J.-D. \& Cloetingh, S., 1998. Mechanical controls on collision-related compressional intraplate deformation. Tectonophysics 300 : 103-129.

Zoback, M.L., 1992. First- and second-order patterns of stress in the lithosphere: the World Stress Map Project. Journal of Geophysical Research 97: 11703-11728.

Zoback, M.L. \& World Stress Map Team, 1989. Global pattern of tectonic stress. Nature 341: 291-298. 